\title{
Bees of the family Halictidae Thomson, 1869 from Dominica, Lesser Antilles (Hymenoptera: Apoidea)
}

\author{
Jason GIBBS \\ Department of Entomology, Michigan State University, 578 Wilson Road, East Lansing, \\ Michigan 48824, USA. Email: dialictus@gmail.com \\ urn:1sid:zoobank.org:author:BA42A49F-3EBC-4679-8F03-A58E798106B1
}

\begin{abstract}
The bees of the family Halictidae Thomson, 1869 from Dominica are reviewed. Seven new species are described and illustrated: Lasioglossum (Dialictus) kalinago sp. nov., L. (D.) dominicense sp. nov., L. (D.) kilpatrickae sp. nov., L. (Habralictellus) roseauense sp. nov., Sphecodes diablotinus sp. nov., S. albifacies sp. nov. and Habralictus antillarus sp. nov. A description and images of the previously unknown female of Microsphecodes dominicanus (Stage, 1972) are provided. In total, eleven species are recognized: eight nest-building species and three kleptoparasites. All halictid species from Dominica are currently known only from the island. A key to halictid bees from Dominica is provided.
\end{abstract}

Keywords. Caenohalictini, Halictini, Sphecodini, taxonomy, West Indies.

Gibbs J. 2016. Bees of the family Halictidae Thomson, 1869 from Dominica, Lesser Antilles (Hymenoptera: Apoidea). European Journal of Taxonomy 180: 1-50. http://dx.doi.org/10.5852/ejt.2016.180

\section{Introduction}

The Commonwealth of Dominica is a small island in the Caribbean Sea, with a total area of approximately $750 \mathrm{~km}^{2}$ and reaching a maximum elevation of $1447 \mathrm{~m}$. Dominica is at approximately the midpoint of the Lesser Antilles chain of islands, belonging to the so-called Windward Islands. The bee diversity of the Lesser Antilles remains poorly studied, particularly for the family Halictidae Thomson, 1869. Halictid bees occurring in the Lesser Antilles have been recorded and described from several Windward Islands, including Dominica (Crawford 1914; Eickwort \& Stage 1972; Gibbs 2012), and islands to the south such as Grenada (Smith-Pardo 2009), Trinidad and Tobago (Hook et al. 2014), and St. Vincent and the Grenadines (Ashmead 1900). A small number of halictid bees have been reported from the Leeward Islands Saint Kitts, Saint John and Sombrero, Anguilla and the Virgin Islands to the north of Dominica (Engel 2001b, 2006a, 2011; Genaro \& Franz 2008). Islands adjacent to Dominica, such as Guadeloupe and Martinique, do not have any halictid bees currently listed in their faunae (Ascher \& Pickering 2015; Meurgey 2014), but they do occur on these islands (A. Pauly, pers. comm.).

The bee fauna of Dominica was first reviewed by Crawford (1914), who recognized 15 species at the time and described two halictid bees. Eighteen bee species are currently recognized from Dominica; most are relatively large-bodied apid and megachilid bees which are not endemic to the island (Ascher 
\& Pickering 2015; Gibbs 2012; Moure 2007). The halictid fauna of Dominica currently comprises four species, all endemic to the island (Gibbs 2012). These are Augochlora ignifera Crawford, 1914, Lasioglossum punctifrons (Crawford, 1914), Microsphecodes dominicanus (Stage in Eickwort \& Stage, 1972) and Habralictus gonzalezi Gibbs, 2012. Gibbs (2012) also documented the occurrence of two unknown species of Lasioglossum Curtis, 1833 (Dialictus Robertson, 1902a) and one Sphecodes Latreille, 1804. These new species, as well as two additional species of Lasioglossum, one additional Sphecodes, and one new Habralictus Moure, 1941 are described herein, bringing the total bee fauna of Dominica to twenty-five species. These new species descriptions are provided to better document the bee fauna of this region and to allow future comparisons to other islands in the Lesser Antilles.

\section{Material and methods}

This work is part of a continuing effort to revise the Lasioglossum species of North America (Gibbs 2009a, 2009b, 2010, 2011; Gibbs et al. 2013). A large number of specimens have been examined from the West Indies, including relevant type material, with the goal of revising the Lasioglossum species in the region. West Indian specimens have been examined from the following collections (abbreviations indicate institutions with specimens from Dominica or type material examined):

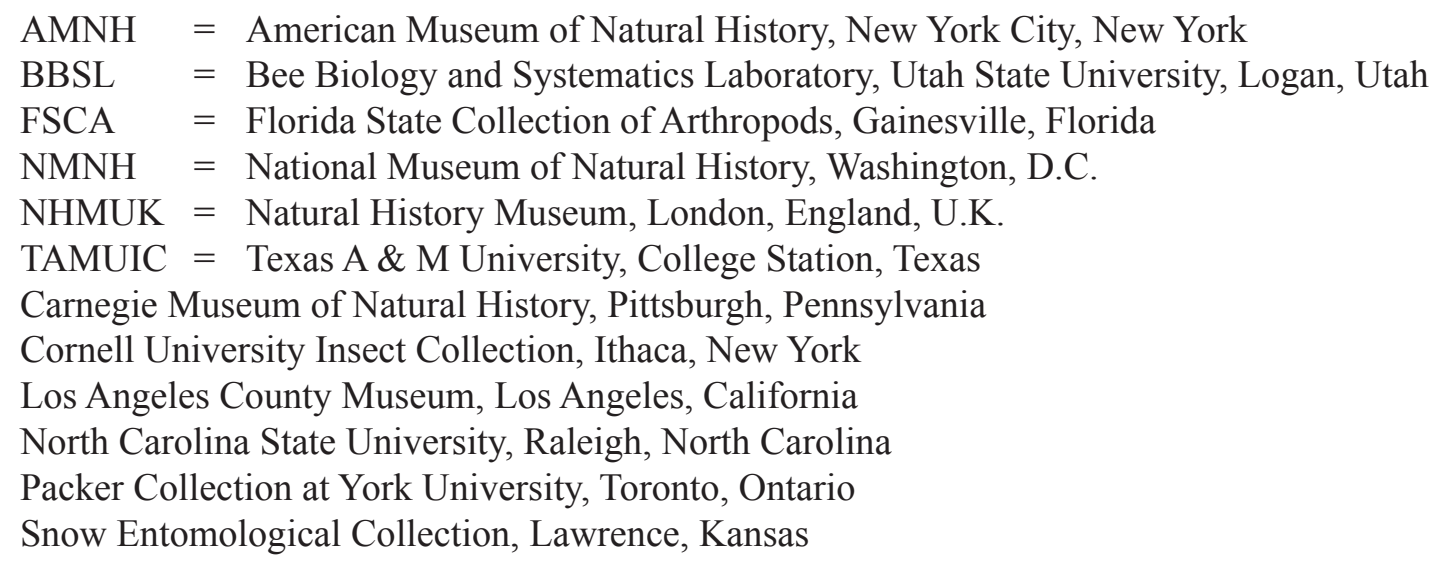

This study is based largely on specimens collected from the Archbold Tropical Research and Education Center (ATREC; abbreviated ATRC on some label information below), Dominica, including voucher material from a previously published study (Wells \& Decker 2006). More specific information on collection sites and methods is available from that study. ATREC is located in St. Paul Parish, although some labels from this location incorrectly read "Parish of St. Joseph, Springfield Estate". Additional material from the NMNH was collected largely during the Bredin-Archbold-Smithsonian Biological Survey of Dominica (Evans 1972).

Descriptions follow those of other halictid bees (Gibbs 2009a, 2009b, 2010, 2011, 2012; Gibbs et al. 2013). Puncture density is given as the length of interspaces between punctures (i) measured in terms of puncture diameter (pd). Metasomal terga are abbreviated ' $\mathrm{T}$ ' followed by the appropriate segment number. Antennal flagellomeres are abbreviated ' $F$ ' followed by the appropriate flagellomere number. Terminology for structures follows earlier studies on bees (Engel 2001a; Gibbs 2011; Michener 2007). A published glossary of insect surface sculpturing was used as the basis for sculpture terms in the descriptions (Harris 1979). Tribal names for halictid bees are based on those proposed from a familylevel phylogeny (Danforth et al. 2004). Photographs were taken using a Canon MPE-65 macro lens on a 70D or T3i body. Composite images were produced using Zerene Stacker and edited in Photoshop Elements 12. 


\title{
Results
}

\author{
Family Halictidae Thomson, 1869 \\ Tribe Halictini Thomson, 1869 \\ Genus Lasioglossum Curtis, 1933 \\ Subgenus Dialictus Robertson, 1902a
}

Paralictus Robertson, 1901: 229 (type species: Halictus cephalicus Robertson, 1892, by original designation).

Dialictus Robertson, 1902a: 48 (type species: Halictus anomalus Robertson, 1892, by original designation and monotypy).

Chloralictus Robertson, 1902b: 248 (type species: Halictus cressonii Robertson, 1890, by original designation).

Halictus (Gastrolictus) Ducke, 1902: 102 (type species: Halictus osmioides Ducke, 1902, by monotypy). Halictomorpha Schrottky, 1911: 81 (type species: Halictomorpha phaedra Schrottky, 1911, by original designation).

Rhynchalictus Moure, 1947: 5 (type species: Rhynchalictus rostratus Moure, 1947, by original designation).

Halictus (Smeathhalictus) Warncke, 1975: 88 (type species: Melitta smeathmanella Kirby, 1802, by original designation).

Lasioglossum (Afrodialictus) Pauly, 1984: 142 (type species: Halictus bellulus Vachal, 1909, by original designation).

Gnathalictus Moure, 2001: 493 (type species: Gnathalictus capitatus Moure, 2001, by original designation).

Evylaeus (Viridihalictus) Pesenko, 2007: 25 (type species: Halictus viridis Brullé, 1840, by original designation).

Evylaeus (Glauchalictus) Pesenko, 2007: 26 (type species: Halictus problematicus Blüthgen, 1823, by original designation).

Evylaeus (Virenshalictus) Pesenko, 2007: 26 (type species: Hylaeus virens Erichson, 1835, by original designation).

Evylaeus (Loethalictus) Pesenko, 2007: 26 (type species: Halictus loetus Brullé, 1840, by original designation).

Evylaeus (Aerathalictus) Pesenko, 2007: 27 (type species: Melitta aerata Kirby, 1802, by original designation).

Lasioglossum (Dialictus) kalinago sp. nov. urn:1sid:zoobank.org:act:C2694FD3-089E-4D80-88E9-C1D073203893

Fig. $1 \mathrm{~A}-\mathrm{C}$

\section{Diagnosis}

Lasioglossum kalinago sp. nov. females can be distinguished from congenerics in Dominica by the presence of dark mesoscutal setae; other characters which are diagnostic in combination include the following: mesepisternum punctation indistinct dorsally, dull due to microsculpture; head wider than long (length/width ratio $=0.9$; Fig. 1A); mesoscutal punctures distinct; and T1 appressed setal fan complete. Lasioglossum dominicense sp. nov. is smaller in size, with deep and distinct punctures throughout the mesepisternum including the hypostomal area. Lasioglossum kilpatrickae sp. nov. has a longer head (length/width ratio $=1.0$; Fig. 5A) and distinct mesepisternal punctures. Lasioglossum punctifrons $($ Crawford, 1914) has a longer head (length/width ratio $=1.0$; Fig. 7A), granular microsculpture with indistinct punctation and lacks a complete $\mathrm{T} 1$ appressed setal fan. Lasioglossum roseauense sp. nov. has only two submarginal cells and lacks a T1 fan. The male of L. kalinago sp. nov. is unknown. 

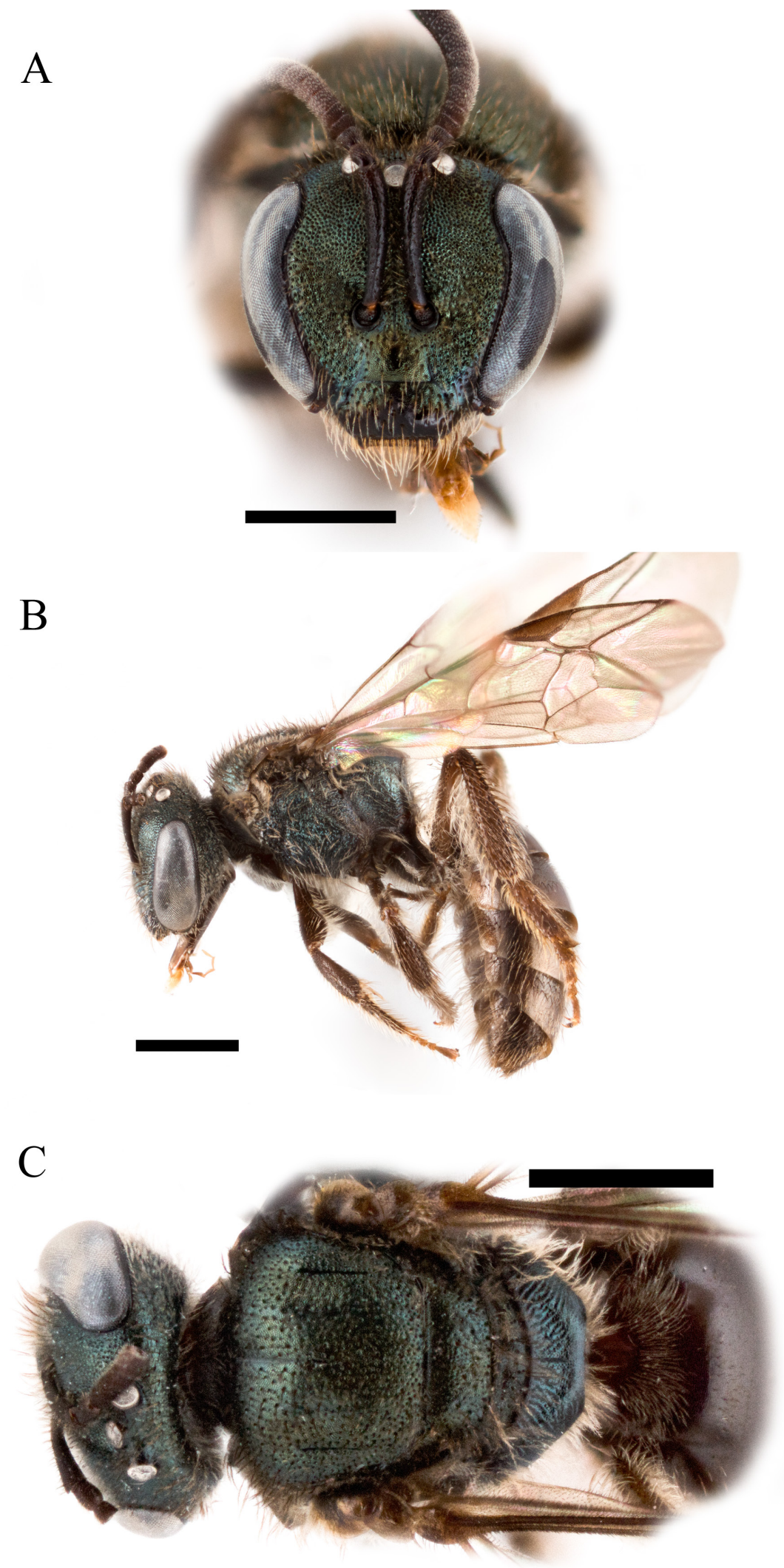

Fig. 1. Lasioglossum (Dialictus) kalinago sp. nov. Holotype (A) and paratype (B-C), $q$ +. A. Face. B. Lateral habitus. C. Dorsum of mesosoma. Scale bars $=1 \mathrm{~mm}$. 


\section{Etymology}

The specific epithet is named for the indigenous people of the island. It is treated as a noun in apposition.

\section{Type material}

\section{Holotype}

DOMINICA: +, St. Paul Parish, "Parish of St. Joseph" [sic], Springfield Estate, $15.34667^{\circ}$ N, $61.3683^{\circ} \mathrm{W}$, 430 m, 15-20 Mar. 2003, coll. M.E. Irwin \& M. Shepard, Malaise trap (BBSL).

\section{Paratypes}

DOMINICA: $3 q$, St. Paul Parish, topotypical (BBSL); 1 , St. Paul Parish, ATR[E]C Springfield, Fifi trail, 'site 2', $15^{\circ} 21^{\prime} \mathrm{N}, 61^{\circ} 22^{\prime}$ W, $442 \mathrm{~m}, 24$ May-4 Jun. 2003, coll. T. Decker \& W. Wells, Malaise trap, voucher \#645 (TAMUIC); 1 q, St. Paul Parish, ATREC, Springfield, $345 \mathrm{~m}, 15.34656^{\circ} \mathrm{N}, 61.36901^{\circ} \mathrm{W}$, 7-8 Jun. 2014, coll. S.K. Kilpatrick, pan traps (TAMUIC).

\section{Description}

\section{Female}

Measurements ( $\mathrm{n}=4)$. Length 4.3-5.0 $\mathrm{mm}($ mean $=4.6)$; head length 1.2-1.4 mm (mean = 1.3); head width 1.4-1.6 mm $($ mean $=1.5)$; intertegular distance $1.0-1.3 \mathrm{~mm}($ mean $=1.2)$.

Colouration. Head and mesosoma dull metallic green with some blue reflections, except as follows. Labrum brown. Mandible brown with red apex. Clypeus distal half dark brown. Supraclypeal area bronze. Antenna dark brown, flagellum with ventral surface dark reddish brown. Tegula dark reddish brown. Wing membrane faintly dusky with dark setae, venation and pterostigma brown. Legs dark brown, except medio- and distitarsi reddish brown. Metasomal terga blackish brown.

PubesCENCE. Dull white, intermixed with darker setae on mesoscutum, dorsal surface of metatibia, and metasomal terga. Relatively sparse erect setae throughout, without tomentum, except narrow basolateral patches of T2-T3. T1 with complete fan of appressed setae on anterior surface. T2 without apical fimbriae, T3-T4 with only sparse fine setae on apical impressed areas. Scopa well developed on hind leg and metasomal sterna.

SURFACE SCULPTURE. Face imbricate, punctation moderately coarse, finer on frons. Clypeus punctation sparse $(i=1-2.5 \mathrm{pd})$, surface smooth distally $(\mathrm{i}=2-3 \mathrm{pd})$, supraclypeal area with punctures sparse, absent medially $(\mathrm{i}=1-2.5 \mathrm{pd})$ and lower paraocular area punctation dense $(\mathrm{i} \leq \mathrm{pd})$. Upper paraocular area and frons reticulate-punctate $(1<\mathrm{pd})$. Ocellocular area punctate $(\mathrm{i} \leq \mathrm{pd})$. Gena and postgena finely carinulate. Mesoscutum with tessellate-imbricate punctation moderately coarse, dense on lateral and posterior portions $(1<\mathrm{pd})$, sparser on anterior portions and medially $(\mathrm{i}=1-1.5 \mathrm{pd})$; mesoscutellum similar, with small submedial impunctate area $(i=1-2 \mathrm{pd})$. Metanotum imbricate. Preëpisternum rugulose. Hypoepimeral area finely rugulose. Mesepisternum below scrobe reticulate-rugulose $(1<\mathrm{pd})$, imbricate ventrally with coarse punctures. Metepisternum dorsal $1 / 3$ rugoso-carinulate, ventral portion imbricate. Metapostnotum medially with irregular rugae reaching $2 / 3$ distance to posterior margin, oblique carinulae on lateral portions extending to dorsolateral slope. Propodeum posterior and lateral surfaces polished tessellate, with some fine carinulae. Metasomal terga polished, finely coriarious on T1 anterior surface and apical impressed areas; punctation fine, obscure on basal portions ( $\mathrm{i}=1-2 \mathrm{pd}$ ), virtually absent on apical impressed area of T2, very obscure on apices of remaining segments. Metasomal sterna coriarious and finely, sparsely punctate $(i=2-4 \mathrm{pd})$.

Structure. Head round (length/width ratio $=0.9$ ). Eyes weakly convergent below. Clypeus $1 / 2$ below suborbital tangent. Gena narrower than eye. Hypostomal carinae subparallel. Pronotal dorsolateral angle 
obtuse. Pronotal ridge rounded, interrupted by sulcus. Tegula ovoid. Submarginal cells three (1rs-m present). Distal hamuli arranged 2-1-2. Inner metatibial spur pectinate, with 3-4 branches, proximal branch much longer than width of rachis. Metapostnotum slight depressed, narrowly rounded onto posterior propodeal surface. Propodeum with lateral carina nearly reaching dorsal margin; oblique carina distinct. T2-T4 impressed areas medially nearly equal to longitudinal length of basal area.

\section{Male \\ Unknown.}

\section{Remarks}

Lasioglossum kalinago sp. nov. bears some similarity to other West Indian species, such as L. magdalena (Baker, 1906), L. sanctivincenti (Ashmead, 1900) and L. plumbeum (Ashmead, 1900). Lasioglossum magdalena is from Cuba and has finer punctation and a more polished mesepisternum. Specimens from the type series of L. sanctivincenti, L. plumbeum and L. cyaneum (Ashmead, 1900), collected in St. Vincent and the Grenadines and deposited in the NHMUK and NMNH, were examined in 2012 and 2015. Images of specimens from the type series of the latter two species are available from the NMNH. Non-types of L. sanctivincenti and L. plumbeum from St. Vincent and the Grenadines (deposited at FSCA) were also examined, and these species were found to be distinct from the Dominica fauna. Lasioglossum kalinago sp. nov. can be distinguished from these species based on multiple characters, including the distinct mesepisternal punctures of L. sanctivincenti, the long head of L. plumbeum and the bright blue metasoma of L. cyaneum.

Lasioglossum (Dialictus) dominicense sp. nov. urn:1sid:zoobank.org:act:95421366-50BE-49F3-B51C-91B51E7A0A90

Figs $2 \mathrm{~A}-\mathrm{C}, 3 \mathrm{~A}-\mathrm{C}, 4 \mathrm{~A}-\mathrm{B}$

\section{Diagnosis}

Lasioglossum dominicense sp. nov. females have the following characteristics: head wider than long (length/width ratio = 0.9; Fig. 2A); mesoscutal and mesepisternal punctures distinct (Fig. 2B-C); mesoscutal setae entirely pale; submarginal cells three; and T1 appressed setal fan complete. The male is similar but lacks a T1 fan. Lasioglossum kilpatrickae sp. nov. is larger, with a distinctly longer head in both sexes (length/width ratio =1.0; Figs 5A, 6A). Lasioglossum kalinago sp. nov. is larger in size, with less distinct punctures on the mesepisternum and dark setae intermingled with pale setae on the mesoscutum. Lasioglossum punctifrons has a longer head, granular microsculpture with indistinct punctation, and lacks a complete T1 appressed setal fan. Lasioglossum roseauense sp. nov. has only two submarginal cells.

\section{Etymology}

The specific epithet refers to the collection locality in the Commonwealth of Dominica.

\section{Type material}

\section{Holotype}

DOMINICA: ㅇ, ATR[E]C Springfield, Mt. Joy trail, 'site 3', 152 $21^{\prime}$ N, $61^{\circ} 22^{\prime}$ W, 424 m, 25 May-4 Jun. 2003, coll. T. Decker \& W. Wells, Malaise trap, voucher \# 645 (TAMUIC).

\section{Paratypes}

DOMINICA: 3 q , St. Paul Parish, "Parish of St. Joseph" [sic], Springfield Estate, $15.34667^{\circ}$ N, $61.3683^{\circ} \mathrm{W}, 430 \mathrm{~m}, 15-20$ Mar. 2003, coll. M.E. Irwin \& M. Shepard, Malaise trap (BBSL); 1 ,

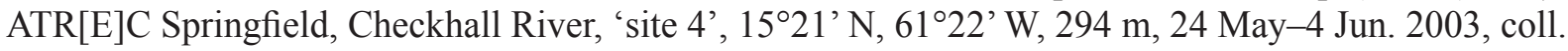


A
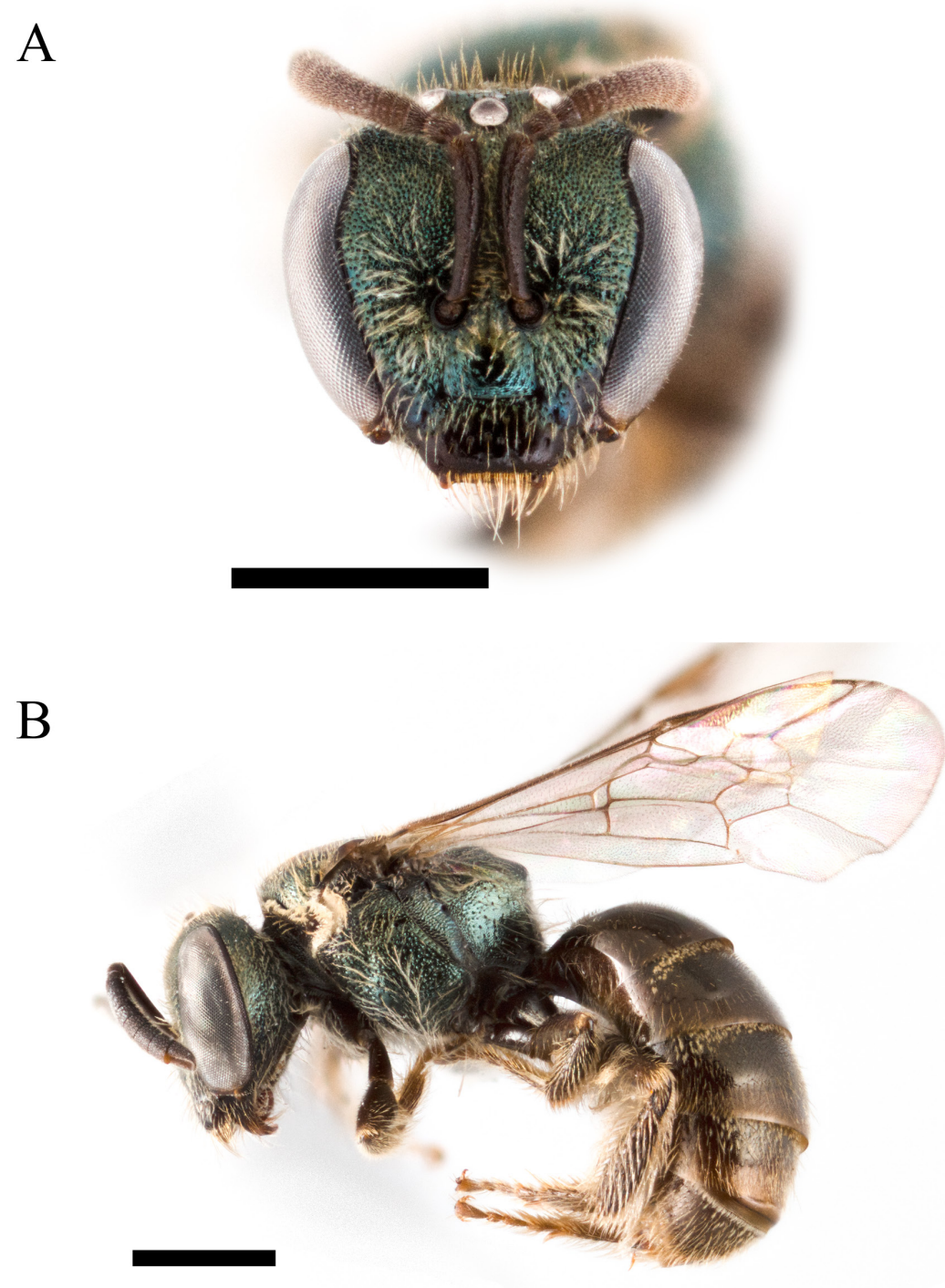

$\mathrm{C}$

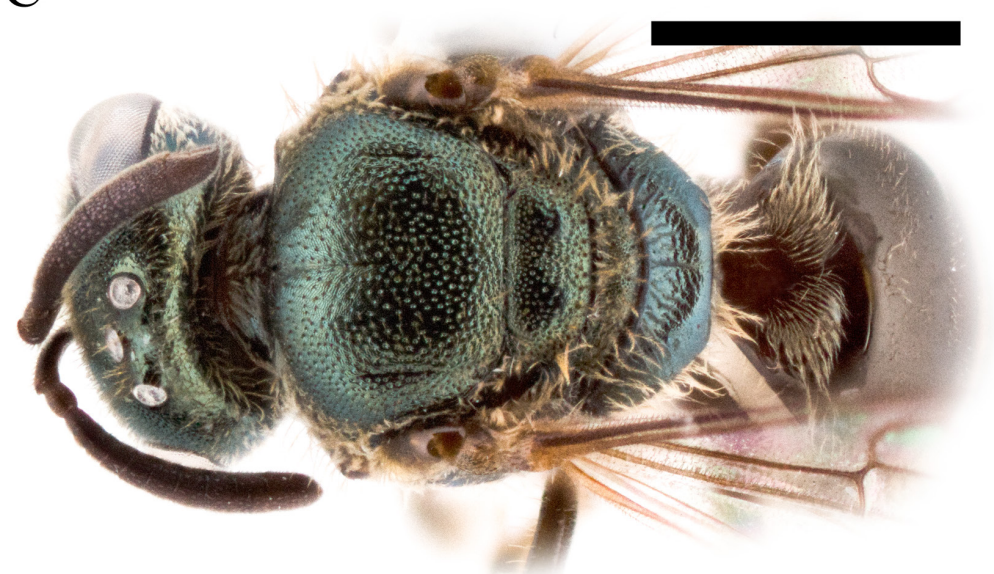

Fig. 2. Lasioglossum (Dialictus) dominicense sp. nov. Holotype (A, C) and paratype (B), $q$ + . A. Face. B. Lateral habitus. C. Dorsum of mesosoma. Scale bars $=1 \mathrm{~mm}$. 
T. Decker \& W. Wells, Malaise trap, voucher \# 645 (TAMUIC); 2 우, ATREC, Springfield, 345 m, $15.34656^{\circ} \mathrm{N}, 61.36901^{\circ} \mathrm{W}, 31$ May 2014, coll. S.K. Kilpatrick, pan traps (TAMUIC); 1 \%, ATREC, Springfield, $345 \mathrm{~m}, 15.34656^{\circ} \mathrm{N}, 61.36901^{\circ} \mathrm{W}, 3$ Jun. 2014, coll. S.K. Kilpatrick, pan traps (TAMUIC); 8 우, 슬, ATREC, Springfield, $345 \mathrm{~m}, 15.34656^{\circ} \mathrm{N}, 61.36901^{\circ}$ W, 5 Jun. 2014, coll. S.K. Kilpatrick, pan traps (TAMUIC); 2 우, ATREC, Springfield, $345 \mathrm{~m}, 15.34656^{\circ} \mathrm{N}, 61.36901^{\circ} \mathrm{W}, 6$ Jun. 2014, coll. S.K. Kilpatrick, pan traps (TAMUIC); 5 우, 1 ㄱ. ATREC, Springfield, $345 \mathrm{~m}, 15.34656^{\circ} \mathrm{N}, 61.36901^{\circ} \mathrm{W}$, 7-8 Jun. 2014, coll. S.K. Kilpatrick, pan traps (TAMUIC); 3 우, Springfield, Nov. 1967, coll. N.L.H. Krauss (NMNH); 1 ㅇ, St. George Parish, Long Ditton, 20 Jun. 1911 (AMNH); 2 ồ , Roseau, 0-100 m, Jul. 1976, coll. N.L.H. Krauss (NMNH).

\section{Description}

\section{Female}

Measurements $(\mathrm{n}=8)$. Length 3.5-3.8 $\mathrm{mm}($ mean $=3.6)$; head length $1.1-1.2 \mathrm{~mm}(\mathrm{mean}=1.1)$; head width $1.2-1.3 \mathrm{~mm}($ mean $=1.2)$; intertegular distance $0.8-1.0 \mathrm{~mm}($ mean $=0.9)$.

Colouration. Head and mesosoma dull metallic golden-green, except as follows. Labrum brown. Mandible brown with red apex. Clypeus distal half dark brown. Supraclypeal area bronze. Antenna dark brown, flagellum with ventral surface dark reddish brown. Tegula dark reddish brown. Wing membrane hyaline with dark setae, venation and pterostigma brown. Legs dark brown, except medio- and distitarsi and portions of metabasitarsus reddish brown. Metasomal terga blackish brown, reddish brown apically.

Pubescence. Dull white. Relatively sparse erect setae throughout, without tomentum, except on gena near eye, pronotum dorsolateral angles and lobe, narrow basolateral patches of T2-T3 and sparsely on T4. Metasomal T1 with complete fan of appressed setae on anterior surface. T2 without apical fimbriae, T3-T4 with only sparse, fine setae on apical impressed areas. Scopa well developed on hind leg and metasomal sterna.

SURFACE SCULPTURE. Face imbricate, punctation moderately fine. Clypeus punctation sparse $(i=1-2.5$ pd), denser proximally, surface smooth distally $(i=2-3 \mathrm{pd})$. Supraclypeal area with punctures sparse, present medially $(\mathrm{i}=1-2 \mathrm{pd})$, and lower paraocular area punctation dense $(\mathrm{i} \leq \mathrm{pd})$. Upper paraocular area and frons reticulate-punctate $(1<\mathrm{pd})$. Ocellocular area punctate $(\mathrm{i} \leq \mathrm{pd})$. Gena and postgena polished, finely punctate-lineolate. Mesoscutum imbricate, punctation moderately fine, dense on laterad of parapsidal lines, posterior portion $(1<\mathrm{pd})$, sparser medially ( $\mathrm{i}=1-2 \mathrm{pd})$; mesoscutellum similar, with small submedial impunctate area $(i=1-2 \mathrm{pd})$. Metanotum imbricate. Preëpisternum finely reticulate rugulose. Hypoepimeral area finely punctate. Mesepisternum below scrobe punctate $(1<\mathrm{pd})$, finely imbricate. Metepisternum dorsal $1 / 3$ rugulose, ventral portion imbricate. Metapostnotum medially with irregular rugae reaching $2 / 3$ distance to posterior margin, oblique carinulae on lateral portions extending to dorsolateral slope. Propodeum posterior and lateral surfaces polished tessellate. Metasomal terga polished, finely coriarious on apical impressed areas, T1 anterior face polished; punctation fine, obscure on basal portions $(\mathrm{i}=1-2 \mathrm{pd})$, indistinct, sparser on apical impressed areas. Metasomal sterna coriarious and finely, sparsely punctate $(i=2-4 \mathrm{pd})$.

Structure. Head round (length/width ratio $=0.9$ ). Eyes weakly convergent below. Clypeus $1 / 2$ below suborbital tangent. Gena narrower than eye. Hypostomal carinae subparallel. Pronotal dorsolateral angle obtuse. Pronotal ridge rounded, interrupted by sulcus. Tegula ovoid. Submarginal cells three (1rs-m present). Distal hamuli arranged 2-1-2. Inner metatibial spur pectinate, with 3-4 branches, proximal branch much longer than width of rachis. Metapostnotum narrowly rounded onto posterior propodeal surface. Propodeum with lateral carina reaching $2 / 3$ distance to dorsal margin; oblique carina fine. T2-T4 impressed areas medially about $1 / 2$ longitudinal length of basal area. 
A

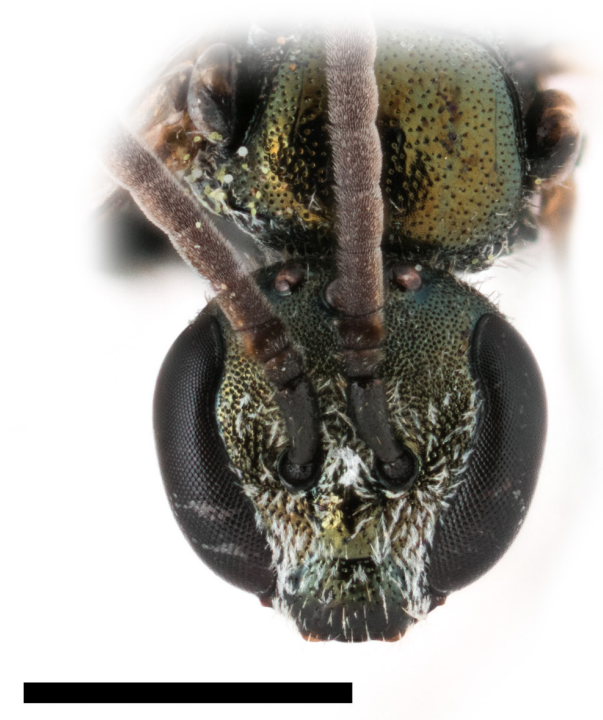

B

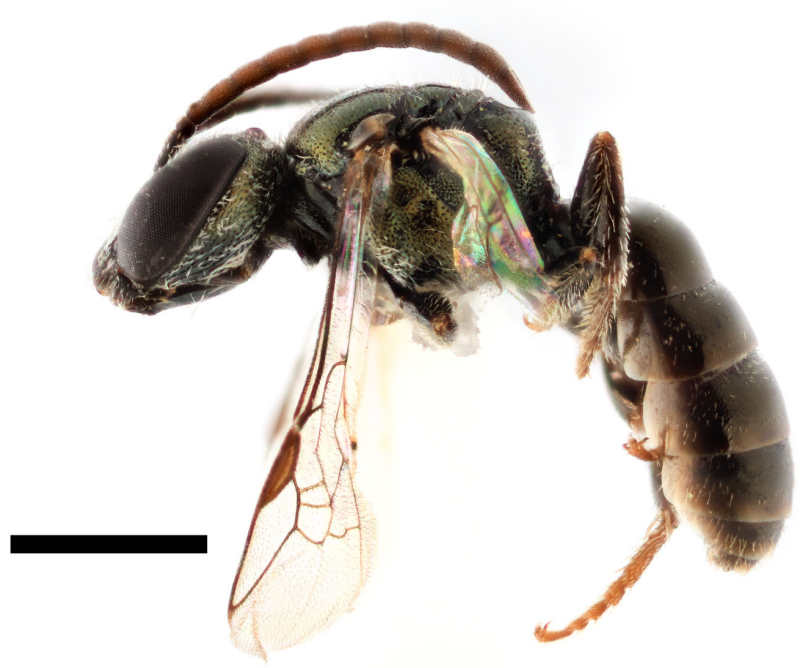

C

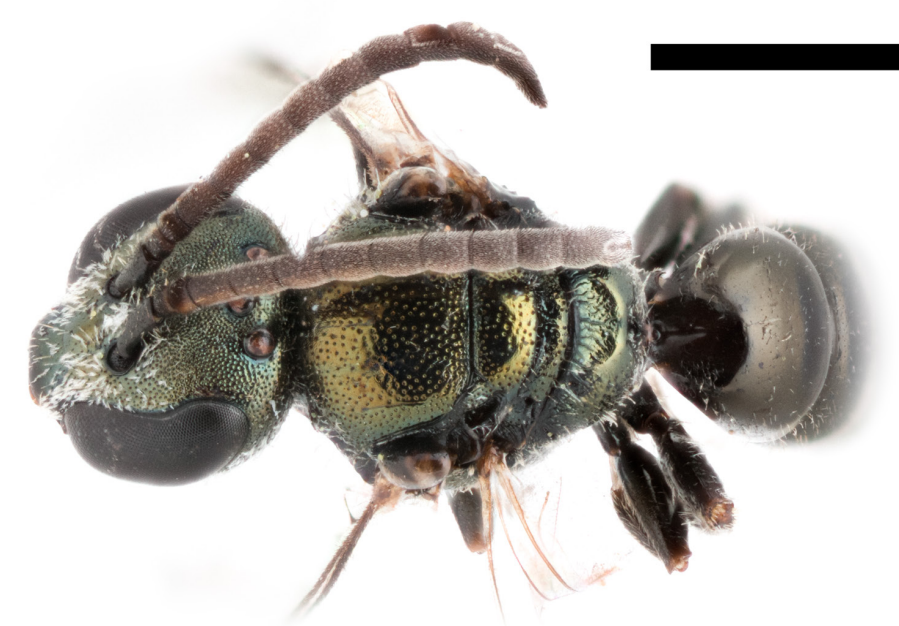

Fig. 3. Lasioglossum (Dialictus) dominicense sp. nov. Paratype, ठ․ A. Face. B. Lateral habitus. C. Dorsum of mesosoma. Scale bars $=1 \mathrm{~mm}$. 

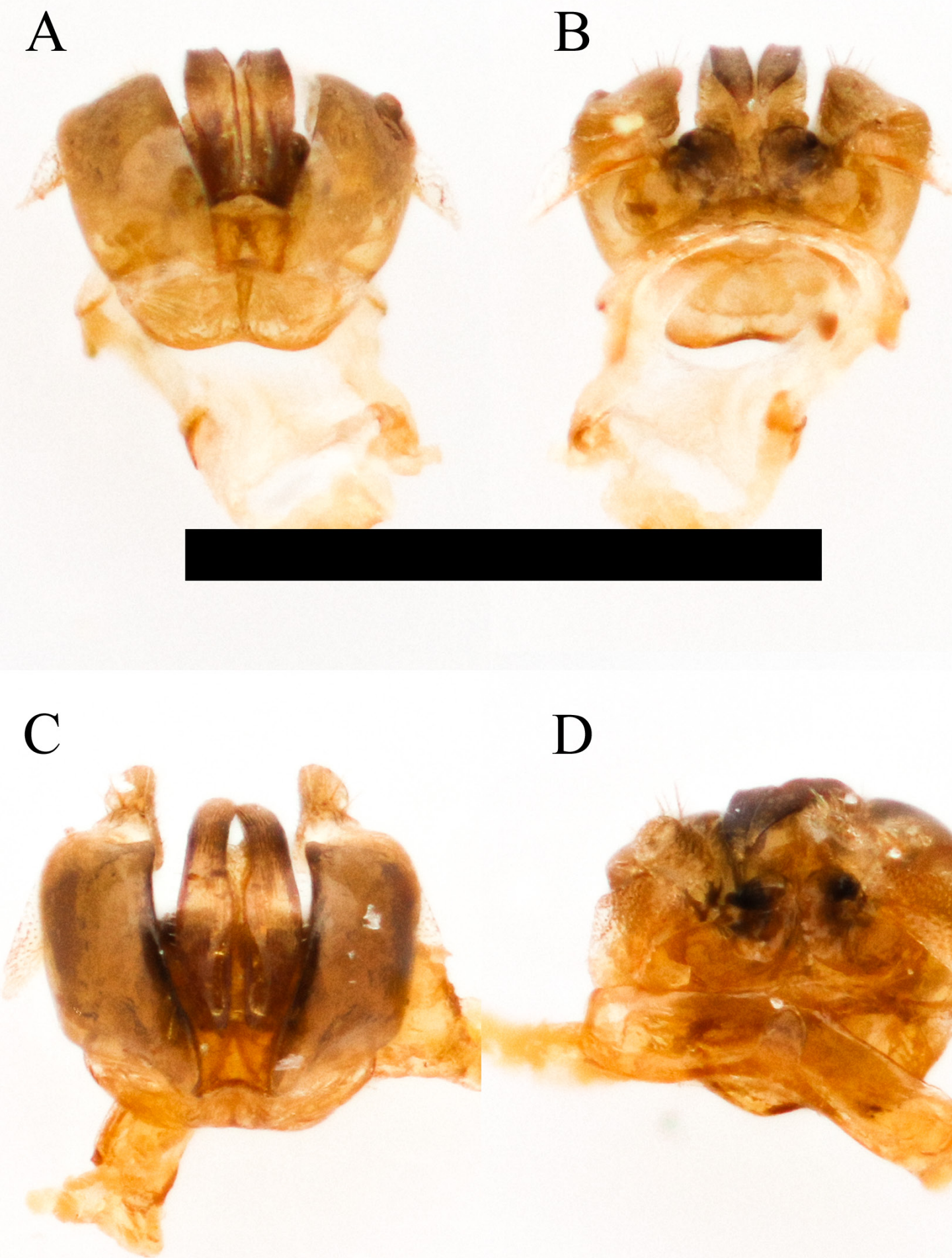

$\mathrm{D}$

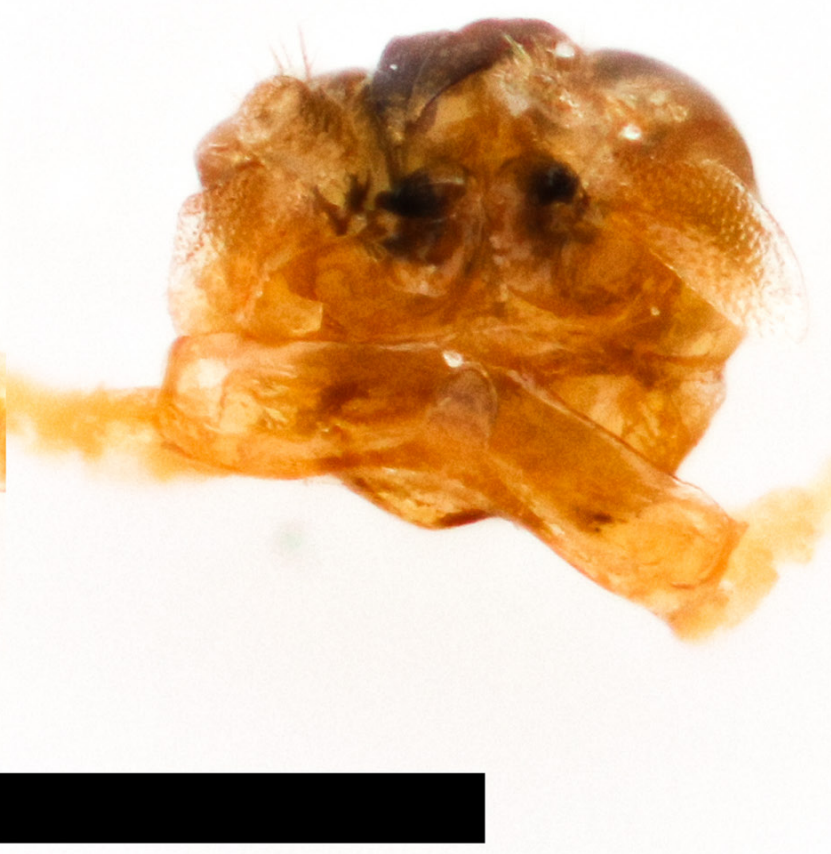

Fig. 4. - Genital capsule of Lasioglossum (Dialictus) dominicense sp. nov. Paratype, Ô. A. Dorsal view. B. Ventral view. - Genital capsule of Lasioglossum (Dialictus) kilpatrickae sp. nov. Paratype, ð̃. C. Dorsal view. D. Ventral view. Scale bars $=1 \mathrm{~mm}$. 


\section{Male}

Measurements $(\mathrm{n}=1)$. Length $4.4 \mathrm{~mm}$; head length $1.2 \mathrm{~mm}$; head width $1.2 \mathrm{~mm}$; intertegular distance $0.8 \mathrm{~mm}$.

Colouration. Similar to female, except tarsi reddish.

PuBESCENCE. Similar to female, except scopa absent. Lower paraocular area with sparse tomentum. T1 fan absent. T2-T4 without evident tomentum.

SuRfaCe SCULPTURE. Similar to female, but more polished, with less evident imbricate microsculpture. Metanotum sparsely punctate $(\mathrm{i}=1-1.5 \mathrm{pd})$ Metepisternum punctate. Lateral surface of propodeum distinctly punctate. T1-T4 apical impressed areas impunctate.

Structure. Similar to female, with typical sexual differences. Head round (length/width ratio $=0.97$ ). F2 length nearly $2 \times$ F1. Scape, pedicel and F1 reaching lower margin of median ocellus. Antenna reaching posterior margin of mesosoma. T2-T4 apical impressed areas less than $1 / 3$ of median length.

Terminalia. As shown in Fig. 4A-B.

\section{Remarks}

Lasioglossum dominicense sp. nov. bears some superficial resemblance to members of the L. parvum species group in its size and overall appearance, but it lacks the enlarged tegula diagnostic for that complex. It is perhaps most similar to L. sanctivincenti, and could easily be considered a subspecies based on the close similarity to that species. Lasioglossum sanctivincenti appears to have more distinct microsculpture throughout, which is most apparent in the interspaces of the mesoscutum and the anterior face of T1. The puncture density mesad of the parapsidal line is slightly denser $(1<\mathrm{pd})$ and more numerous to a distance of about 3-4 puncture diameters from the parapsidal line. If the species were sympatric it would be challenging to differentiate them and any variation in the above characters would make distinguishing them next to impossible. A more comprehensive survey of the intervening islands would be useful for clarifying the biogeographic history of these and other species in the Lesser Antilles.

Lasioglossum (Dialictus) kilpatrickae sp. nov. urn:1sid:zoobank.org:act:90970C96-A443-4BFA-A205-6A7E6332EC95 Figs $4 \mathrm{C}-\mathrm{D}, 5 \mathrm{~A}-\mathrm{C}, 6 \mathrm{~A}-\mathrm{C}$

\section{Diagnosis}

Lasioglossum kilpatrickae sp. nov. females have the following characteristics: head at least as long as wide (length/width ratio $=1.0$; Fig. 5A); mesoscutal and mesepisternal punctures distinct (Fig. 5B-C); mesoscutal setae entirely pale; and T1 appressed setal fan complete. The male is similar but lacks a T1 fan. Lasioglossum dominicense sp. nov. is smaller, with a distinctly shorter head in both sexes (length/width $=0.9$ ) (Figs 2A, 3A). Lasioglossum kalinago sp. nov. has less distinct punctures on the mesepisternum and dark setae intermingled with pale setae on the mesoscutum. Lasioglossum punctifrons has granular microsculpture with indistinct punctation (Fig. 7B) and lacks a complete T1 appressed setal fan.

\section{Etymology}

This species is named for Shelby Kilpatrick (TAMUIC), who collected most of the type series and arranged additional Dominican bee specimens for study. 
A

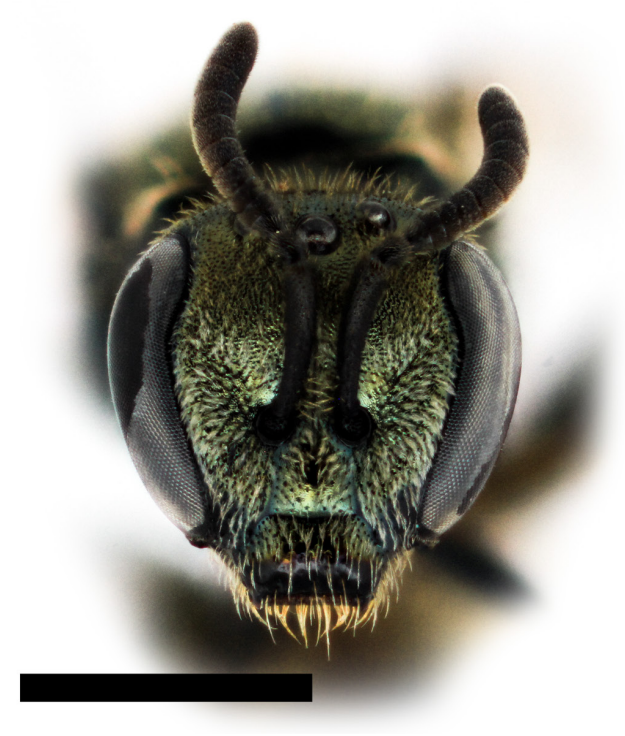

B
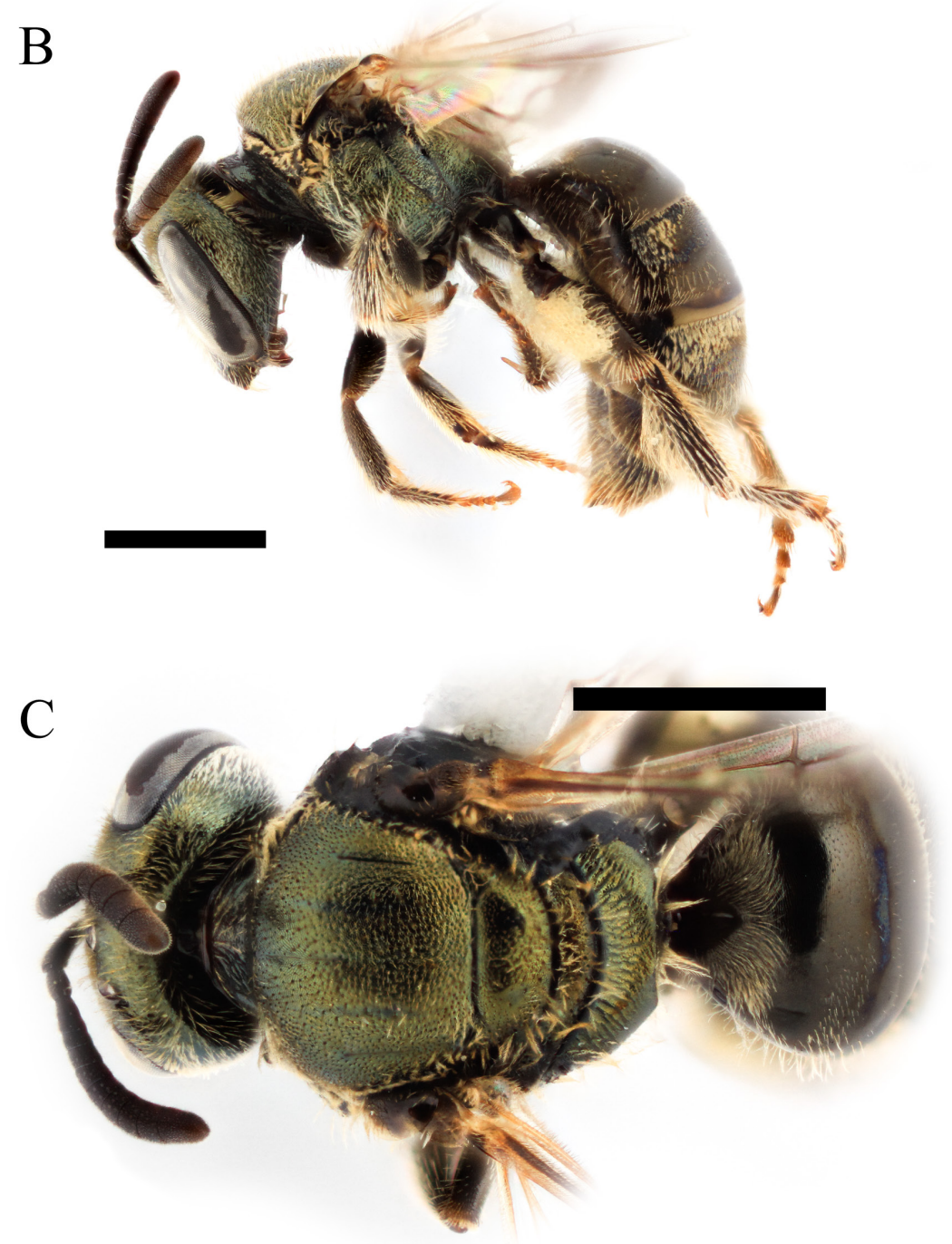

Fig. 5. Lasioglossum (Dialictus) kilpatrickae sp. nov. Holotype, ․ A. Face. B. Lateral habitus. C. Dorsum of mesosoma. Scale bars $=1 \mathrm{~mm}$. 


\section{Type material}

\section{Holotype}

DOMINICA: + , St. David Parish, Castle Bruce Beach \& Estuary, $15.432225^{\circ} \mathrm{N}, 61.25539^{\circ} \mathrm{W}, 10 \mathrm{~m}$, 8 Jun. 2015, coll. S.K. Kilpatrick \& R. Selking, sweeping (TAMUIC).

\section{Paratypes}

DOMINICA: 1 +, 2 $\widehat{\jmath}$, St. David Parish, topotypical (TAMUIC); 1 §, St. Andrew Parish, Wo[o]dford Hill, 5-7 Jun. 1987, coll. R.E. Woodruff (FSCA).

\section{Description}

\section{Female}

MeAsuRements $(\mathrm{n}=1)$. Length $4.7 \mathrm{~mm}$; head length $1.2 \mathrm{~mm}$; head width $1.2 \mathrm{~mm}$; intertegular distance $1.0 \mathrm{~mm}$

Colouration. Head and mesosoma dull metallic golden-green, except as follows. Labrum brown. Mandible brown with red apex. Clypeus distal half dark brown. Antenna dark brown, flagellum with ventral surface dark reddish brown. Tegula dark reddish brown. Wing membrane hyaline with dark setae, venation and pterostigma brown. Legs dark brown, except medio- and distitarsi and portions of metabasitarsus reddish brown. Metasomal terga blackish brown, reddish brown apically.

Pubescence. Dull white. Relatively sparse erect setae throughout, without tomentum, except on gena near eye, pronotum dorsolateral angles and lobe, narrow basolateral patches of T2-T3 and sparsely on T4. Metasomal T1 with complete fan of appressed setae on anterior surface. T2 without apical fimbriae, T3-T4 with only sparse fine setae on apical impressed areas. Scopa well developed on hind leg and metasomal sterna.

SuRFACE SCULPTURE. Face imbricate, punctation moderately fine. Clypeus punctation sparse $(\mathrm{i}=1-2.5 \mathrm{pd})$, denser proximally, surface smooth distally $(i=2-3 \mathrm{pd})$. Supraclypeal area with punctures sparse, present medially $(\mathrm{i}=1-2 \mathrm{pd})$, and lower paraocular area punctation dense $(\mathrm{i} \leq \mathrm{pd})$. Upper paraocular area and frons reticulate-punctate $(1<\mathrm{pd})$. Ocellocular area punctate $(\mathrm{i} \leq \mathrm{pd})$. Gena and postgena polished, finely punctate-lineolate. Mesoscutum imbricate, punctation fine, dense on laterad of parapsidal lines, posterior portion $(1<\mathrm{pd})$, slightly sparser medially $(\mathrm{i}=1-1.5 \mathrm{pd})$, submedial areas sparser still; mesoscutellum similar with small submedial impunctate area $(i=1-2 \mathrm{pd})$. Metanotum finely punctate. Preëpisternum finely reticulate rugulose. Hypoepimeral area finely punctate. Mesepisternum below scrobe punctate $(\mathrm{i} \leq \mathrm{d})$, finely imbricate. Metepisternum dorsal $1 / 3$ rugulose, ventral portion imbricate. Metapostnotum medially with longitudinal rugae reaching posterior margin, oblique carinulae on lateral portions extending to dorsolateral slope. Propodeum posterior and lateral surfaces polished tessellate. Metasomal terga polished, finely coriarious on apical impressed areas and T1 anterior face; punctation fine, obscure on basal portions ( $\mathrm{i}=1-2 \mathrm{pd})$, indistinct, sparser on apical impressed areas, T1-T2 apical impressed areas impunctate, except near lateral margins. Metasomal sterna coriarious and finely, sparsely punctate $(\mathrm{i}=2-4 \mathrm{pd})$.

STRUCTURE. Head round $($ length/width ratio $=1.00$ ). Eyes weakly convergent below. Clypeus $2 / 3$ below suborbital tangent. Gena narrower than eye. Hypostomal carinae subparallel. Pronotal dorsolateral angle obtuse. Pronotal ridge rounded, interrupted by sulcus. Tegula ovoid. Submarginal cells three (1rs-m present). Distal hamuli arranged 2-1-2. Inner metatibial spur pectinate, with 3 branches, proximal branch much longer than width of rachis. Metapostnotum narrowly rounded onto posterior propodeal surface. Propodeum with lateral carina reaching $2 / 3$ distance to dorsal margin; oblique carina fine. T2-T4 impressed areas medially about $1 / 2$ longitudinal length of basal area. 

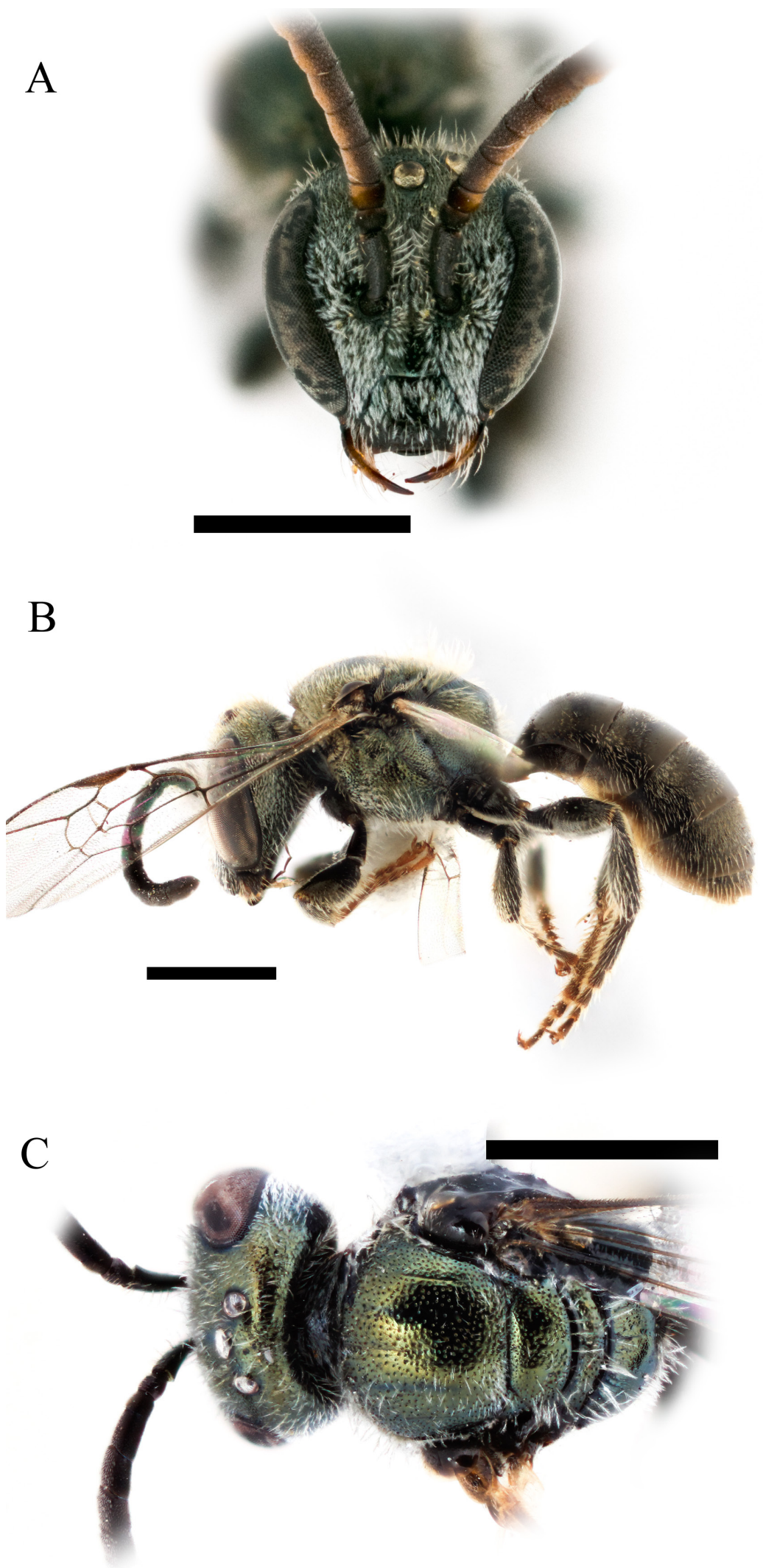

Fig. 6. Lasioglossum (Dialictus) kilpatrickae sp. nov. Paratypes, $ڤ \widehat{\jmath}$. A. Face. B. Lateral habitus. C. Dorsum of mesosoma. Scale bars $=1 \mathrm{~mm}$. 


\section{Male}

Measurements $(\mathrm{n}=3)$. Length 3.9-4.7 $\mathrm{mm}($ mean $=4.4)$; head length 1.3-1.4 mm (mean = 1.4); head width $1.3-1.4 \mathrm{~mm}($ mean $=1.4)$; intertegular distance $0.8-1.0 \mathrm{~mm}($ mean $=0.9)$.

Colouration. Similar to female, except F1-F11 yellowish brown ventrally.

PuBESCEnCE. Similar to female, except scopa absent. Face below eye emargination with sparse tomentum, obscuring lower paraocular area. T1 fan absent. T2-T4 with at most very sparse tomentum basolaterally.

SuRfaCe SCULPTURE. Similar to female, but more polished, with less evident imbricate microsculpture. Metanotum sparsely punctate $(\mathrm{i}=1-1.5 \mathrm{pd})$. Metepisternum densely punctate $(\mathrm{i} \leq \mathrm{pd})$. Metapostnotal rugae not reaching posterior margin. Lateral surface of propodeum distinctly punctate. T1-T4 apical impressed areas impunctate.

StRUCtuRe. Similar to female, with typical sexual differences. Head round (length/width ratio $=1.00$ 1.04). F2 length nearly $2 \times$ F1. Scape, pedicel and F1 reaching lower margin of median ocellus. T2-T4 apical impressed areas less than $1 / 3$ of median length.

Terminalia. As shown in Fig. 4C-D.

\section{Remarks}

Lasioglossum kilpatrickae sp. nov. is similar to L. plumbeum in many respects, most notably the shape of the head. Despite a close similarity, the two species can be readily differentiated. Lasioglossum plumbeum females have distinct medial punctures on the apical impressed area of T2, finer and denser punctures on the mesepisternum, as well as a dark blue colour of the head and mesosoma. Male L. plumbeum lack the tomentum on the lower face present in L. kilpatrickae sp. nov.

Subgenus Habralictellus Moure \& Hurd, 1982

Habralictellus Moure \& Hurd, 1982: 46 (type species: Halictus auratus Ashmead, 1900, by original designation).

Lasioglossum (Habralictellus) punctifrons (Crawford, 1914)

Fig. 7A-B

Halictus punctifrons Crawford, 1914: 133.

\section{Material examined}

\section{Holotype}

DOMINICA: , examined 2015, metasoma not attached, held in capsule on pin, USNM 16733 (NMNH).

\section{Diagnosis}

Lasioglossum punctifrons is distinguished from congenerics on Dominica by any combination of the following characteristics: head as long as wide (length/width ratio $=1.02$; Fig. $7 \mathrm{~A}$ ); mesosoma with granular microsculpture, punctation indistinct (Fig. 7B); metapostnotum long, with weak carinulae limited to lateral margins; and T1 without complete setal fan. Lasioglossum roseauense sp. nov. has a shorter head (length/width ratio $=0.87$; Fig. $8 \mathrm{~A}$ ) and only two submarginal cells. The male is unknown. 


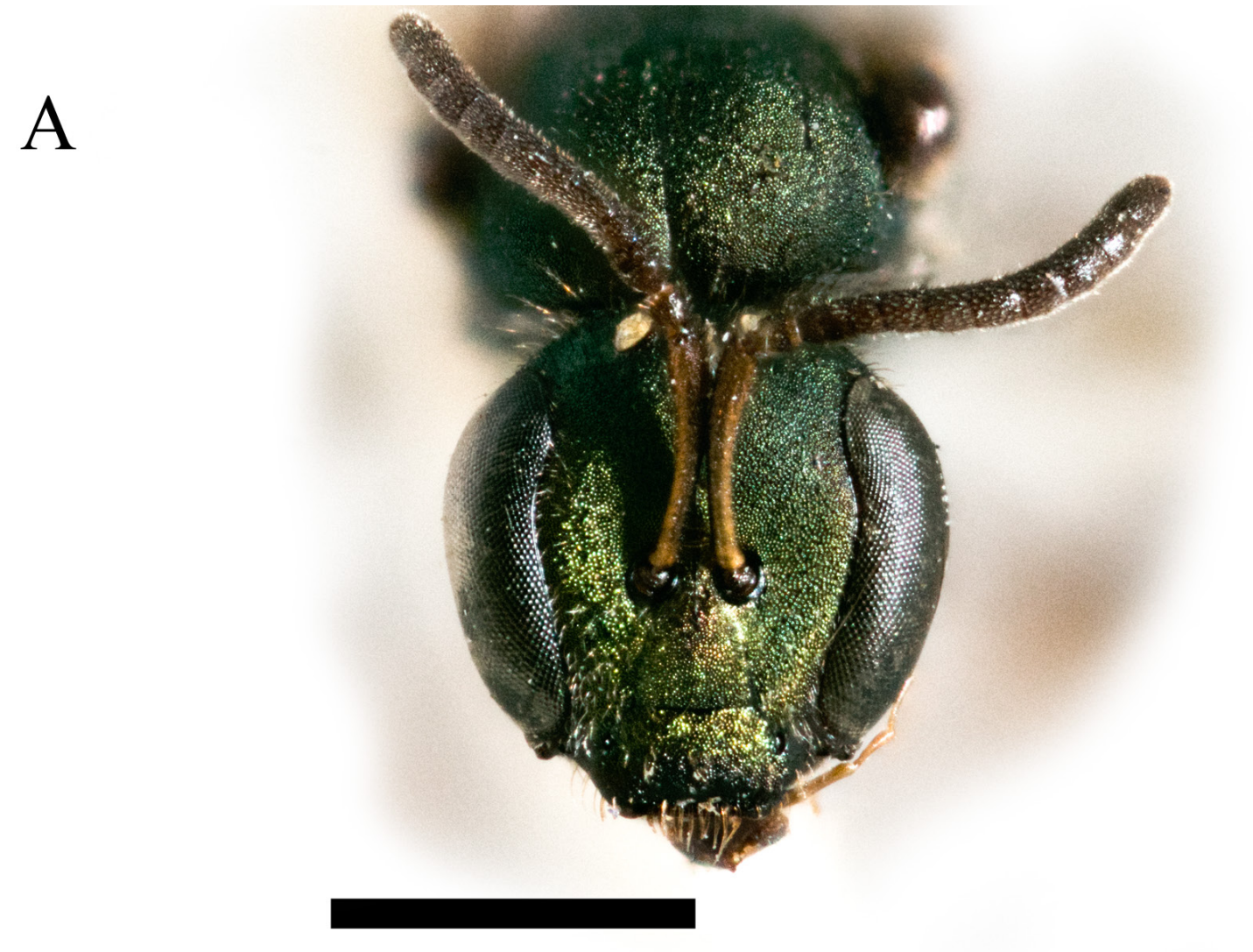

B

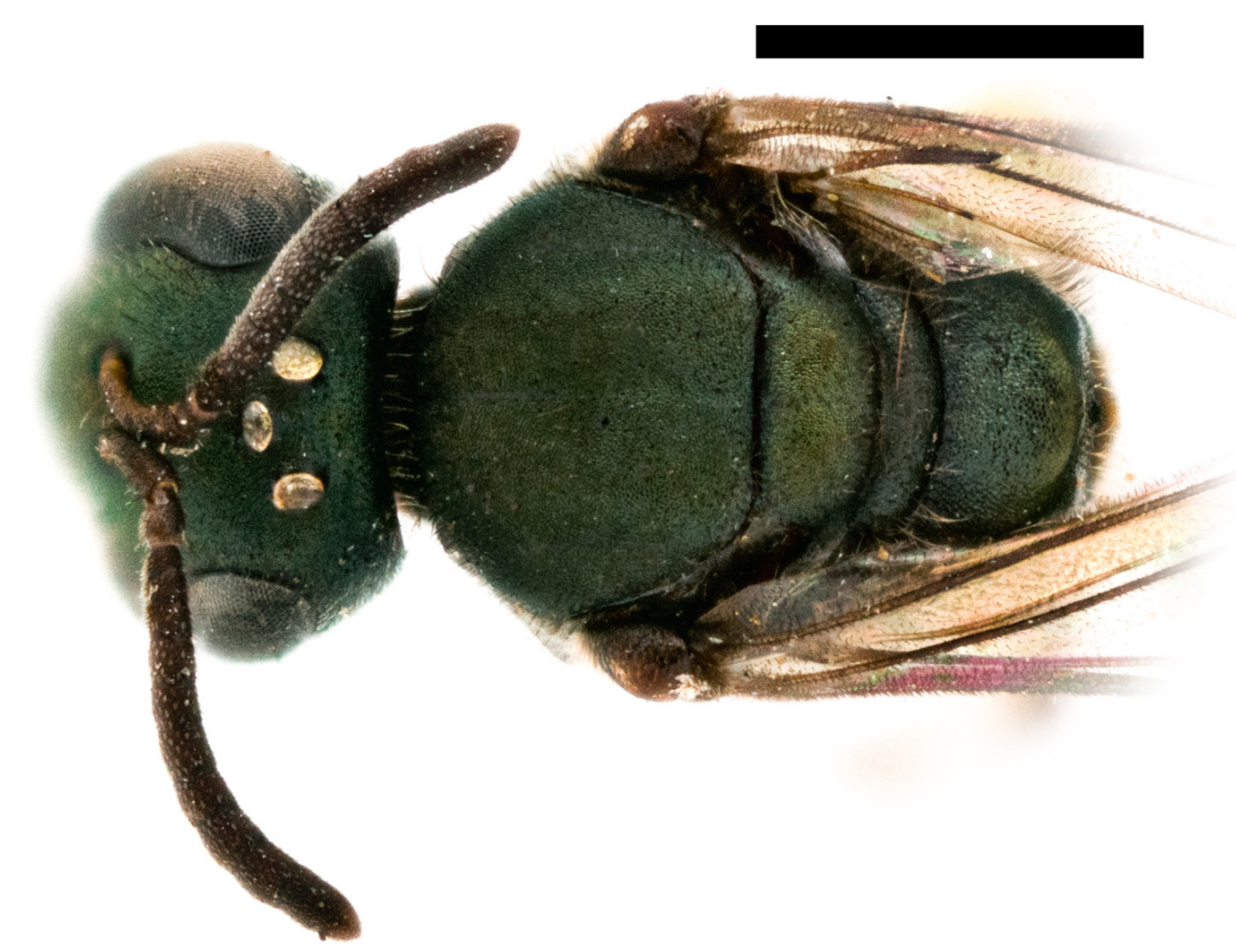

Fig. 7. Lasioglossum (Habralictellus) punctifrons (Crawford, 1914). Holotype, ․ A. Face. B. Dorsum of mesosoma. Scale bars $=1 \mathrm{~mm}$. 


\section{Remarks}

This is clearly a member of the Lasioglossum auratum (Ashmead, 1900) species complex, which has sometimes been recognized as a separate genus, Habralictellus Moure \& Hurd. Many members of this species group, which is endemic to the West Indies, have brilliant iridescent colours on at least the head and mesosoma. The colours are duller in L. punctifrons. The metasoma is entirely dark, without evident metallic reflections. The metapostnotum is elongate, approximately equal in length to the mesoscutellum and metanotum combined, and has only weak carinulae at the lateral margins. The overall structure and sculpturing is very similar to L. auratum, from St. Vincent and the Grenadines, but $L$. auratum has bright iridescent reflections on the head and mesosoma and more distinct carinulae on the metapostnotum, although still largely limited to the lateral parts. The Puerto Rican species L. eickwortellum (Engel, 2001) also belongs to this group and has similar structural features. The female of L. eickwortellum is bright iridescent, with dense but fine punctation on the mesoscutum, and a bright orange-red colour of T1-T2.

No recent collections of L. punctifrons have been examined. To my knowledge it has not been collected since the original survey in 1913.

Lasioglossum (Habralictellus) roseauense sp. nov. urn:1sid:zoobank.org:act:A97639D7-DD8D-475B-B133-852AA955191F

Fig. $8 \mathrm{~A}-\mathrm{C}$

\section{Diagnosis}

The female of $L$. roseauense sp. nov. can easily be recognized by the absence of vein $1 \mathrm{rs}-\mathrm{m}$, resulting in two submarginal cells (Fig. 8B), rather than the three submarginal cells typical of other halictid bees on the island. In addition, the wide face (length/width ratio $=0.87$; Fig. $8 \mathrm{~A}$ ), granular microsculpture and metapostnotum lacking rugae (Fig. 8C) further differentiate this species from congenerics on the island. Lasioglossum punctifrons is easily differentiated by its longer head (length/width ratio $=1.02$; Fig. 7A). Lasioglossum roseauense sp. nov. is superficially similar to Habralictus gonzalezi Gibbs, 2012 and $H$. antillarus sp. nov., but L. roseauense sp. nov. has a weakened vein 2rs-m, typical of Lasioglossum, and more distinct punctation on the mesoscutum.

\section{Etymology}

This species is named for the type locality: Roseau, capital city of Dominica.

\section{Type material}

\section{Holotype}

DOMINICA: + , St. George Parish, Roseau, 8 Mar. 1965, coll. H.E. Evans (NMNH).

\section{Description}

\section{Female}

Measurements $(\mathrm{n}=1)$. Length $5.1 \mathrm{~mm}$; head length $1.3 \mathrm{~mm}$; head width $1.5 \mathrm{~mm}$; intertegular distance $1.1 \mathrm{~mm}$.

Colouration. Head and mesosoma dull metallic bluish to golden green, except as follows. Labrum brown. Mandible brown with red apex. Clypeus distal half dark brown. Antenna dark brown, F7-F10 with ventral surface dark brownish yellow. Tegula brownish yellow. Wing membrane hyaline with dark setae, venation and pterostigma brown. Legs dark brown, except protibia and protarsi brownish yellow, medio- and distitarsi and portions of metabasitarsus reddish brown. Metasomal terga blackish brown, reddish brown apically. 

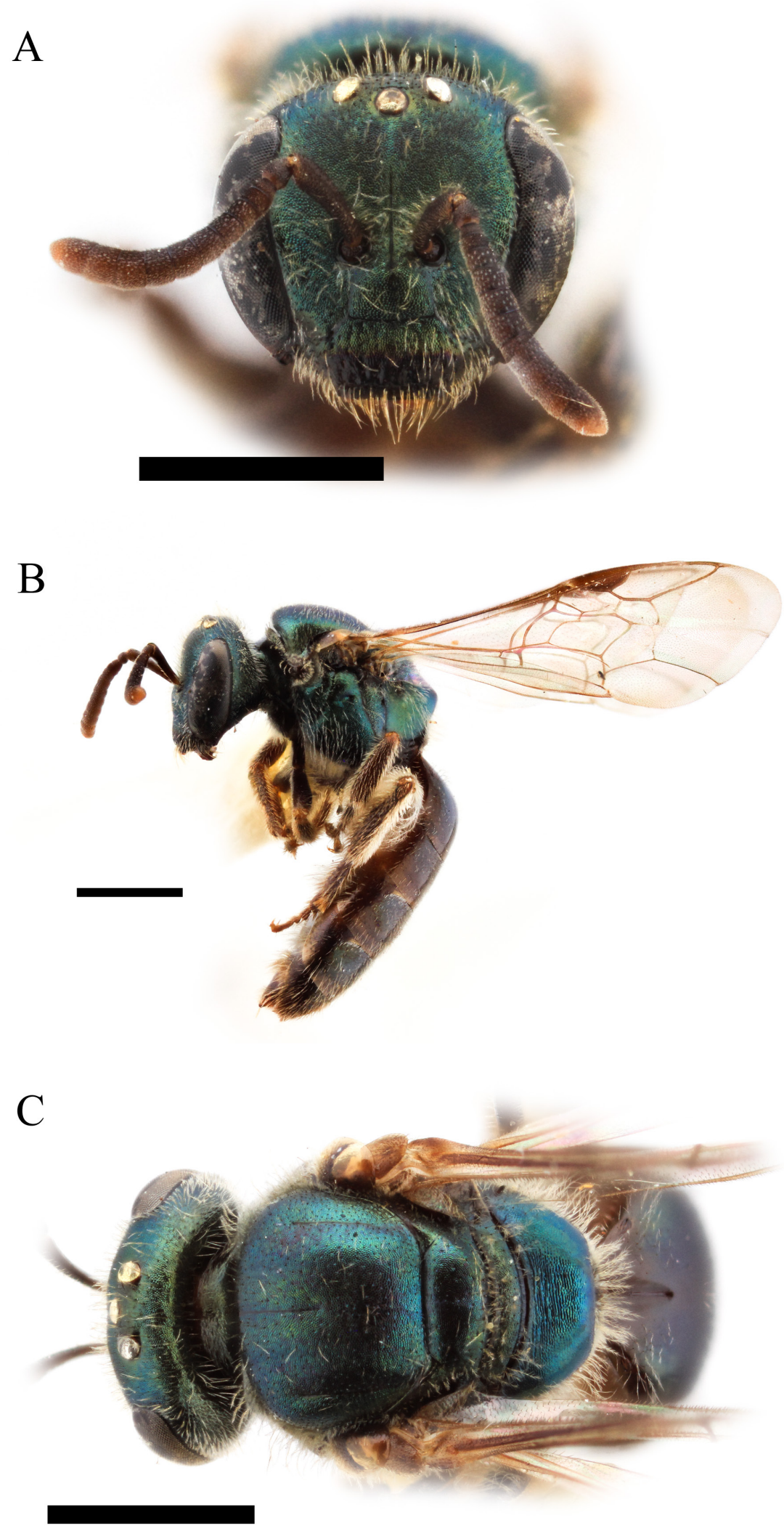

Fig. 8. Lasioglossum (Habralictellus) roseauense sp. nov. Holotype, + . A. Face. B. Lateral habitus. C. Dorsum of mesosoma. Scale bars $=1 \mathrm{~mm}$. 
Pubescence. Dull white. Relatively sparse erect setae throughout, without tomentum, except sparsely on gena near eye and pronotum dorsolateral angles and lobe. Metasomal T1 with erect setae laterally on anterior surface. T2-T4 without apical fimbriae. Scopa well developed on hind leg and metasomal sterna.

SuRfaCe SCULPTURE. Face granular, punctation fine, indistinct. Clypeus punctation sparse $(i=1-2.5 \mathrm{pd})$, surface smooth distally. Supraclypeal area with punctures sparse, present medially ( $\mathrm{i}=1-2 \mathrm{pd}$ ), and lower paraocular area punctation dense $(\mathrm{i} \leq \mathrm{pd})$. Upper paraocular area and frons indistinctly punctuate $(\mathrm{i}=1-2.5 \mathrm{pd})$. Ocellocular area punctate $(\mathrm{i} \leq \mathrm{pd})$. Gena and postgena imbricate-lineolate. Mesoscutum tessellate, punctation fine, relatively dense laterad of parapsidal lines $(i=1.5 \mathrm{pd})$, becoming sparser medially $(i=1.5-4 \mathrm{pd})$; mesoscutellum tessellate, sparsely punctate $(\mathrm{i}=2-5 \mathrm{pd})$. Metanotum granular. Preëpisternum tessellate. Hypoepimeral imbricate. Mesepisternum below scrobe, tessellate-granular, indistinctly punctate ventrally $(\mathrm{i}=2-5 \mathrm{pd})$. Metepisternum dorsal $1 / 3$ carinulate, ventral portion imbricate. Metapostnotum tessellate-granular, transversely lineolate medially. Propodeum posterior and lateral surfaces polished tessellate. Metasomal terga polished, finely coriarious on apical impressed areas; punctation fine, obscure on basal portions ( $\mathrm{i}=1-2 \mathrm{pd})$, indistinct, sparser on apical impressed areas, T1-T2 apical impressed areas with irregular indistinct punctures. Metasomal sterna coriarious, sparsely punctate on posterior half $(\mathrm{i}=2-4 \mathrm{pd})$.

Structure. Head wide $($ length/width ratio $=0.87$ ). Eyes weakly convergent below. Clypeus $1 / 2$ below suborbital tangent. Gena narrower than eye. Hypostomal carinae subparallel. Pronotal dorsolateral angle obtuse. Pronotal ridge rounded, interrupted by sulcus. Tegula ovoid. Submarginal cells three (1rs$\mathrm{m}$ present). Distal hamuli arranged 2-1-2. Inner metatibial spur pectinate, with 5 branches, proximal branch much longer than width of rachis. Metapostnotum narrowly rounded onto posterior propodeal surface. Propodeum with lateral carina reaching $1 / 2$ distance to dorsal margin; oblique carina absent. T2-T4 impressed areas medially about $1 / 2$ longitudinal length of basal area.

\section{Male}

Unknown.

\section{Remarks}

Lasioglossum roseauense sp. nov. belongs to the L. rufopantex (Engel, 2001) species group of L. (Habralictellus), which is recognizable by the short face and absence of vein 1rs-m (Fig. 8A-B). Lasioglossum eleutherense (Engel, 2001) is the only other described member of this complex. Both are known from the Greater Antilles, reaching in the case of L. rufopantex as far as the Virgin Islands. Lasioglossum rufopantex is easily distinguished from L. roseauense sp. nov. by the mesoscutum being polished, iridescent green.

Tribe Sphecodini Schenck, 1868 [1869]

Genus Sphecodes Latreille, 1804

Sphecodes Latreille, 1804: 182 (type species: Nomada gibba Fabricius, $1804=$ Sphex gibba Linnaeus, 1758, by monotypy).

Dichroa Illiger, 1806: 46 (type species: Sphex gibba Linnaeus, 1758, by subsequent designation of Sandhouse, 1943: 545).

Sabulicola Verhoeff, 1890: 328 (type species: Sabulicola cirsii Verhoeff, 1890 = Nomada albilabris Fabricius, 1793, by monotypy).

Thrausmus Buysson, 1900: 177 (type species: Thrausmus grandidieri Buysson, 1900, by monotypy). 
Drepanium Robertson, 1903: 103 (type species: Sphecodes falcifer Patton, $1880=$ Sphecodes confertus Say, 1837, by original designation).

Proteraner Robertson, 1903: 103 (type species: Sphecodes ranunculi Robertson, 1897, by monotypy).

Dialonia Robertson, 1903: 104 (type species: Sphecodes antennariae Robertson, 1891, by original designation).

Machaeris Robertson, 1903: 104 (type species: Sphecodes stygius Robertson, 1893, by original designation).

Sphecodium Robertson, 1903: 104 (= Stelidium Robertson, 1903 lapsus calami, not Stelidium Robertson, 1902c) (type species: Sphecodium cressonii Robertson, 1903, by original designation).

Sphecodes (Callosphecodes) Friese, 1909: 182 (type species: Callosphecodes ralunensis Friese, 1909, by monotypy).

Sphegodes Mavromoustakis, 1948: 553, unjustified emendation.

Sphecodes (Austrosphecodes) Michener, 1978: 327 (type species: Sphecodes chilensis Spinola, 1851, by original designation).

Sphecodes diablotinus sp. nov.

urn:1sid:zoobank.org:act:D309231C-B957-4B22-924D-CD6C4766A93D

Figs 9A-C, 10A-C, 13A, 14A-B

\section{Diagnosis}

The male of $S$. diablotinus sp. nov. can be recognized by the combination of face without tomentose setae (Fig. 9A) and body black. The female of S. diablotinus has the head and mesosoma black, orangered on T1-T4 (Fig. 10B); T2 is nearly impunctate, only sparse punctures are present basally. Both sexes of S. diablotinus sp. nov. have a distinctly smooth triangular area on the posterior margin of the mesepisternum (Fig. 13A). The male of S. albifacies sp. nov. is similar but has dense tomentum on the face (Fig. 11A). The female of S. albifacies sp. nov. is red on T1-T3 (Fig. 12B); T2 has distinct, albeit fine punctation basally. Both sexes have a narrow, indistinct smooth area on the posterior margin of the mesepisternum. Both sexes of Microsphecodes dominicanus (Stage, 1972) have testaceous colour on the mesosoma and reticulate-rugae over the entire metapostnotum (Figs 15B-C, 16B-C).

\section{Etymology}

The specific epithet is based on the local word "diablotin", meaning "little devil", used as a common name for the black-capped kestrel, Pterodroma hasitata (Kuhl, 1820) and the tallest peak on the island, Morne Diablotin.

\section{Type material}

\section{Holotype}

DOMINICA: ${ }^{\wedge}$, St. Paul Parish, Parish of St. Joseph [sic], Springfield Estate, $15.34667^{\circ} \mathrm{N}, 61.3683^{\circ} \mathrm{W}$, 430 m, 15-20 Mar. 2003, coll. M.E. Irwin \& M. Shepard, Malaise trap (BBSL).

\section{Paratypes}

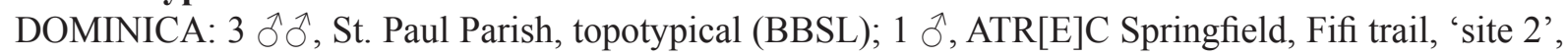
$15^{\circ} 21^{\prime}$ N, 61 ${ }^{\circ} 22^{\prime}$ W, 398 m, 23 May-4 Jun. 2003, coll. T. Decker \& W. Wells, Malaise trap, voucher

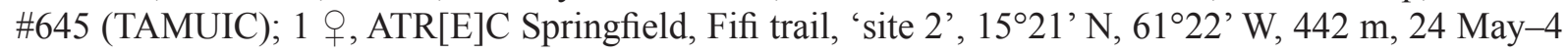
Jun. 2003, coll. T. Decker \& W. Wells, Malaise trap, voucher \#645 (TAMUIC); 1 q, St. Paul Parish,

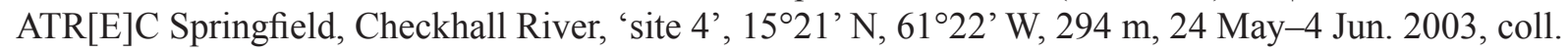
T. Decker \& W. Wells, flight intercept trap, voucher \#645 (TAMUIC); 1 , , St. Joseph Parish, Clarke Hall, 21-31 Jan. 1965, coll. W.W. Wirth, Malaise trap (NMNH). 

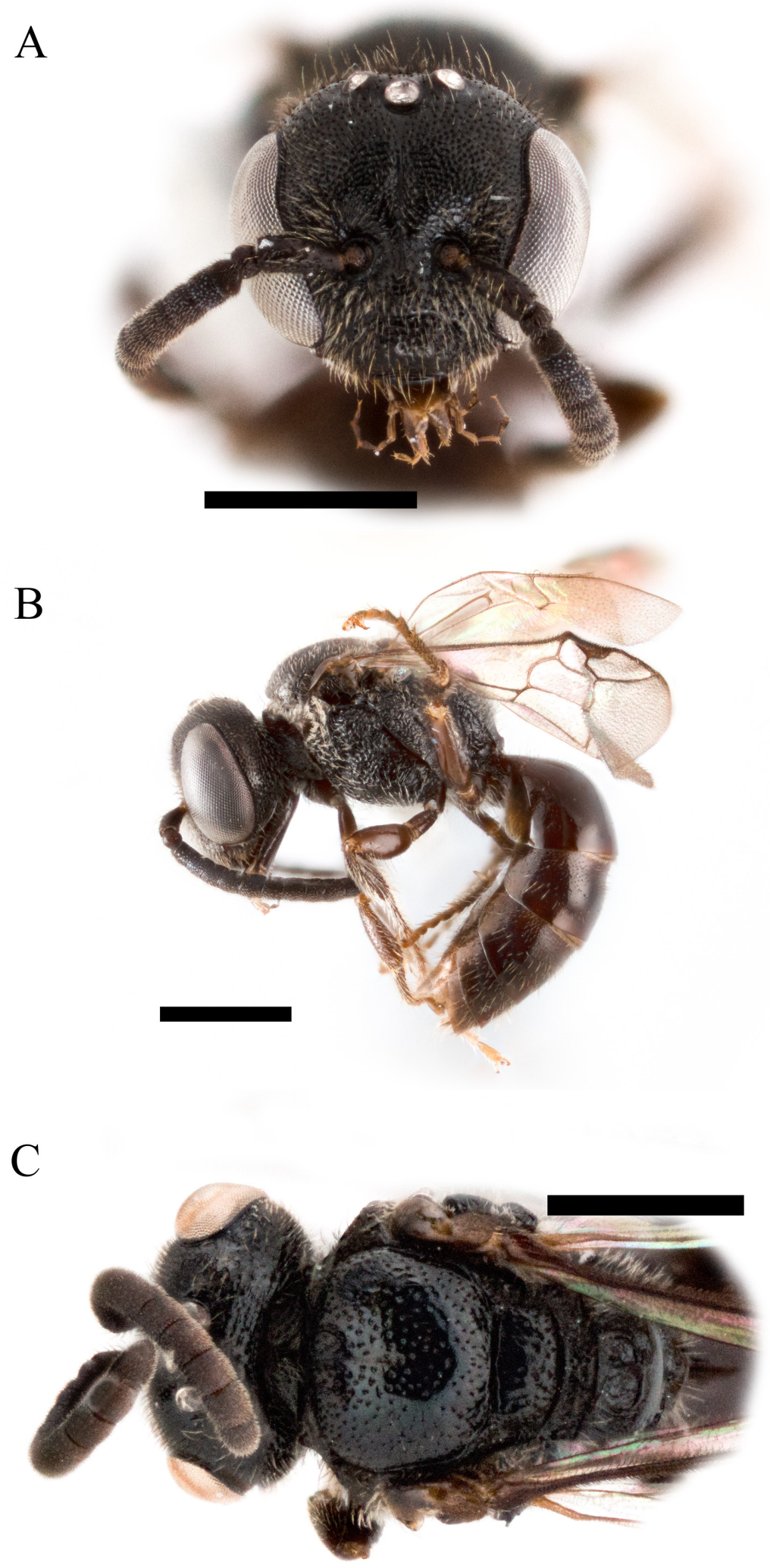

Fig. 9. Sphecodes diablotinus sp. nov. Holotype (A-B) and paratype (C), $\hat{\sigma}^{\hat{\sigma}}$. A. Face. B. Lateral habitus. C. Dorsum of mesosoma. Scale bars $=1 \mathrm{~mm}$. 


\section{Description}

Male

MeAsurements $(\mathrm{n}=2)$. Length $3.8 \mathrm{~mm}$; head length $1.0 \mathrm{~mm}$; head width $1.2 \mathrm{~mm}$; intertegular distance $0.8 \mathrm{~mm}$.

Colouration. Body blackish-brown, except as follows. Mandible yellow with red apex. Clypeus distal half dark brown. Flagellum with ventral surface dark reddish brown. Tegula dark yellowish brown. Wing membrane faintly dusky with dark setae, venation and pterostigma brown. Legs dark brown, except medio- and distitarsi and portions of metabasitarsus reddish brown.

Pubescence. Dull white. Sparse erect setae throughout, without tomentum on head.

SURFACE SCULPTURE. Face polished, punctation fine. Clypeus punctation dense ( $\mathrm{i}=1-1.5 \mathrm{pd})$. Supraclypeal area, lower and upper paraocular areas and frons densely punctate $(\mathrm{i} \leq \mathrm{pd})$. Ocellocular area sparsely punctate $(\mathrm{i}=1-2 \mathrm{pd})$. Gena and postgena polished, finely punctate-lineolate. Mesoscutum polished; punctation moderately coarse, relatively dense laterad of parapsidal lines $(i=1-1.5 \mathrm{pd})$, sparser on posterior and medial area of disc $(\mathrm{i}=1-3 \mathrm{pd})$; mesoscutellum similar. Metanotum rugulose. Preëpisternum reticulate rugulose. Hypoepimeral area finely rugulose. Mesepisternum below scrobe finely rugulose, with smooth posterior triangle, minute punctures present in anteroventral third of triangle. Metepisternum rugulose. Metapostnotum with longitudinal carinulae reaching $2 / 3$ distance to posterior margin, posterior margin smooth. Propodeum posterior and lateral surfaces smooth with irregular sparse rugae. Metasomal terga polished, finely coriarious on apical impressed areas; punctation fine, obscure on basal portions $(i=1-2 \mathrm{pd})$, virtually absent on $\mathrm{T} 1$; apical impressed areas impunctate. Metasomal sterna coriarious and finely, sparsely punctate $(i=2-4 \mathrm{pd})$.

Structure. Head wide (length/width ratio $=0.85-0.86$ ). Eyes weakly convergent below. Clypeus $1 / 2$ below suborbital tangent. Frontal line deeply impressed below median ocellus. Gena narrower than eye. Hypostomal carinae subparallel. Occipital carina small but distinct. Pronotal dorsolateral angle orthogonal. Pronotal ridge carinate, interrupted by sulcus. Tegula ovoid. Submarginal cells two or three (1rs-m present or absent), if $1 \mathrm{rs}-\mathrm{m}$ present then $2^{\text {nd }}$ submarginal cell narrow, posterior length approximately $1 / 2$ anterior length of $3^{\text {rd }}$ submarginal cell. Distal hamuli arranged 2-2. Second tarsal segment narrow at base, length as long as $3^{\text {rd }}$ tarsus. Propodeum with lateral carina reaching $2 / 3$ distance to dorsal margin; oblique carina fine.

Terminalia. As shown in Fig. 14A-B.

\section{Female}

Measurements $(\mathrm{n}=2)$. Length 4.5-4.6 mm (mean $=4.5)$; head length $1.1 \mathrm{~mm}($ mean $=1.1)$; head width $1.3-1.5 \mathrm{~mm}($ mean $=1.4)$; intertegular distance $0.7-0.8 \mathrm{~mm}($ mean $=0.8)$.

Colouration. Body blackish-brown, except as follows. Mandible yellow with red apex. Flagellum with ventral surface dark reddish brown. Tegula dark reddish brown. Wing membrane faintly dusky, with dark setae, venation and pterostigma brown. Legs dark brown, except medio- and distitarsi and portions of metabasitarsus reddish brown. Metasoma T1-T4 reddish orange, T5-T6 and apex of T4 dark brown.

Pubescence. Dull white. Sparse erect setae throughout. Subappressed tomentum on the following: paraocular area below eye emargination, gena, pronotum dorsolateral angle, pronotal lobe, and preëpisternum. Mesofemur and mesotibia without pollen brush. Metafemur without scopa. Metatibia with thick setae on dorsal margin. Penicillis absent. Posterior propodeal surface with sparse short setae below longer erect setae. Metasomal sterna without scopa. 
A
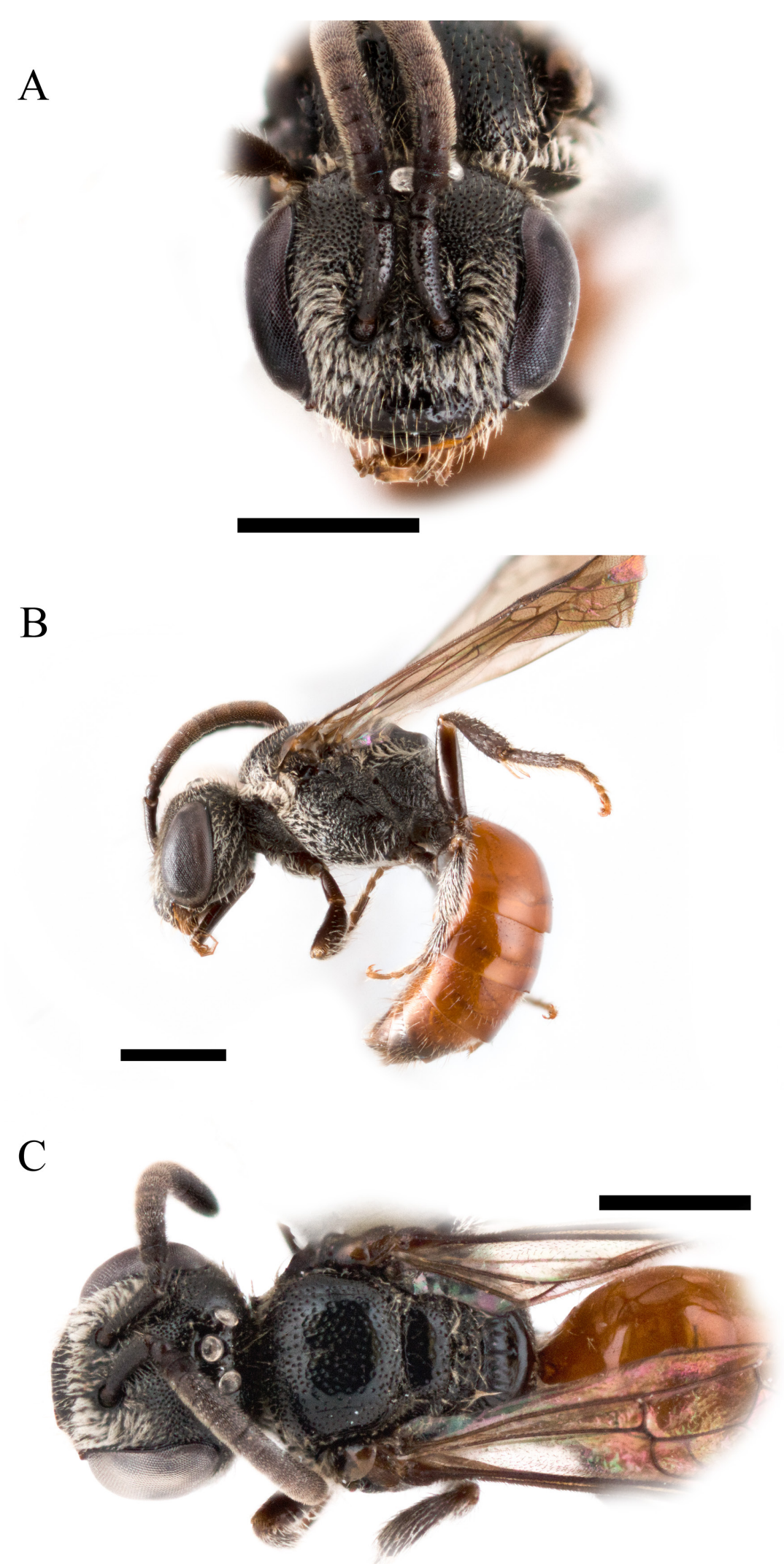

Fig. 10. Sphecodes diablotinus sp. nov. Paratypes, $q$.. A. Face. B. Lateral habitus. C. Dorsum of mesosoma. Scale bars $=1 \mathrm{~mm}$. 
SuRface SCUlPTURE. Face polished, punctation fine. Clypeus punctation dense ( $\mathrm{i}=1-1.5 \mathrm{pd})$. Supraclypeal area, lower and upper paraocular areas and frons densely punctate $(\mathrm{i} \leq \mathrm{pd})$. Ocellocular area sparsely punctate $(\mathrm{i}=1-2 \mathrm{pd})$. Postgena polished, gena finely punctate-lineolate. Mesoscutum polished; punctation moderately coarse, relatively dense laterad of parapsidal lines $(i=1-1.5 \mathrm{pd})$, sparser on posterior and medial area of disc $(i=1-2 \mathrm{pd})$; mesoscutellum similar, submedial patch nearly impunctate. Metanotum rugulose. Preëpisternum reticulate rugulose. Hypoepimeral area finely rugulose. Mesepisternum below scrobe finely rugulose, with smooth posterior triangle expanding ventrally, minute punctures present in anteroventral third of triangle. Metepisternum rugulose. Metapostnotum with longitudinal carinulae reaching $2 / 3$ distance to posterior margin, posterior margin smooth. Propodeum posterior and lateral surfaces reticulate rugulose. T1-T2 polished nearly impunctate, T3-T5 weakly coriarious, basal areas with very fine obscure punctation $(\mathrm{i}=1-3 \mathrm{pd})$, virtually absent on $\mathrm{T} 1$; apical impressed areas impunctate. Metasomal sterna coriarious and finely, sparsely punctate $(i=2-4 \mathrm{pd})$.

STRUCTURE. Head wide (length/width ratio $=0.81-0.82$ ). Eyes weakly convergent below. Labrum broad, without apical projection or dorsal keel. Clypeus $1 / 2$ below suborbital tangent. Mandible simple, without preapical tooth. Gena narrower than eye. Hypostomal carinae subparallel. Occipital carina small but distinct. Flagellum 1 distinctly broader than long on dorsal surface, shorter than pedicel. Pronotal dorsolateral angle acute. Pronotal ridge carinate, interrupted by sulcus. Tegula ovoid. Submarginal cells three (1rs-m present), $2^{\text {nd }}$ submarginal cell narrow, posterior length slightly less than anterior length of $3^{\text {rd }}$ submarginal cell. Distal hamuli arranged 2-2. Inner metatibial spur minutely serrate. Basitibial plate indistinct, represented by minute glabrous spot. Metatarsus 2 narrow at base, length as long as metatarsus 3. Propodeum with lateral carina diverging dorsally, reaching $1 / 2$ distance to dorsal margin; oblique carina indistinct. T5 without evident pseudopygidial area, T6 with narrow pygidial plate.

\section{Remarks}

Hosts of $S$. diablotinus sp. nov. and S. albifacies sp. nov. are unknown, but are presumably among the Lasioglossum (Dialictus) species included herein. Both Sphecodes species have been collected at the same locality as L. kalinago sp. nov., L. dominicense sp. nov. and Habralictus gonzalezi.

Sphecodes albifacies sp. nov. urn:lsid:zoobank.org:act:50B6BF6B-1A37-4D18-89F3-1EF2E996173B

Figs $11 \mathrm{~A}-\mathrm{C}, 12 \mathrm{~A}-\mathrm{C}, 13 \mathrm{~B}, 14 \mathrm{C}-\mathrm{D}$

\section{Diagnosis}

The male of $S$. albifacies sp. nov. can be recognized by the combination of face with dense tomentose setae (Fig. 11A), black body, and metapostnotum with longitudinal carinulae reaching two-thirds of the distance to the smooth posterior margin. The female is similar, but has red on T1-T3 (Fig. 12B). Both sexes have a narrow, indistinct smooth area on the posterior margin of the mesepisternum (Fig. 13B). The male of S. diablotinus sp. nov. is similar but has no tomentum on the face (Fig. 10A). The female of S. diablotinus sp. nov. has red on T1-T4 (Fig. 10B). Both sexes of S. diablotinus sp. nov. have a distinct smooth triangular area on the posterior margin of the mesepisternum (Fig. 13A). Microsphecodes dominicanus has testaceous colour on the mesosoma and reticulate rugae over the entire metapostnotum (Figs 15B-C, 16B-C).

\section{Etymology}

The specific epithet is derived from the Latin for "white face", and is a reference to the dense white pilosity of the male. 
A
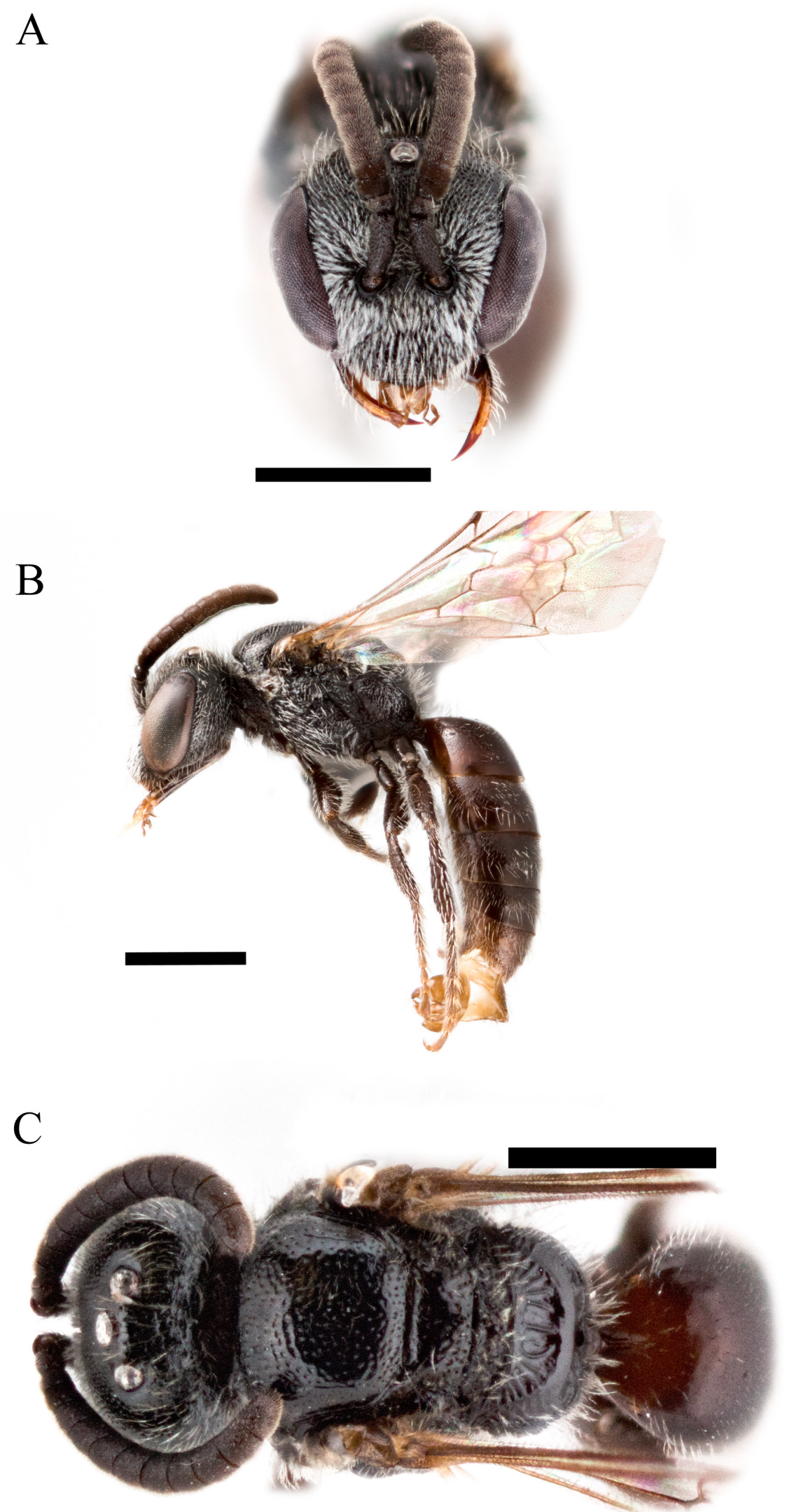

Fig. 11. Sphecodes albifacies sp. nov. Holotype (A) and paratype (B-C), $\widehat{\partial} \widehat{\partial}$. A. Face. B. Lateral habitus. C. Dorsum of mesosoma. Scale bars $=1 \mathrm{~mm}$. 


\section{Type material}

\section{Holotype}

DOMINICA: ${ }^{\lambda}$, St. Paul Parish, Parish of St. Joseph [sic], Springfield Estate, $15.34667^{\circ} \mathrm{N}, 61.3683^{\circ} \mathrm{W}$, 430 m, 15-20 Mar. 2003, coll. M.E. Irwin \& M. Shepard, Malaise trap (BBSL).

\section{Paratypes}

DOMINICA: 2 ๙ึ, St. Paul Parish, topotypical (BBSL); 1 + , ATREC, Springfield, $345 \mathrm{~m}, 15.34656^{\circ}$ N, 61.36901 ${ }^{\circ}$ W, 3 Jun. 2014, coll. S.K. Kilpatrick, pan traps (TAMUIC); 1 \&, ATREC, Springfield, $345 \mathrm{~m}, 15.34656^{\circ} \mathrm{N}, 61.36901^{\circ} \mathrm{W}, 6$ Jun. 2014, coll. S.K. Kilpatrick, pan traps (TAMUIC); 2 우, ATREC, Springfield, $345 \mathrm{~m}, 15.34656^{\circ} \mathrm{N}, 61.36901^{\circ} \mathrm{W}, 7-8$ Jun. 2014, coll. S.K. Kilpatrick, pan

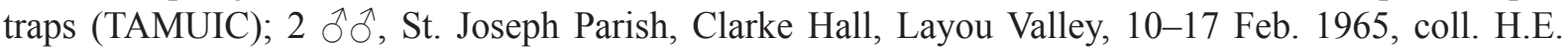
Evans (NMNH); 1 , , Clarke Hall, 19-22 Oct. 1964, coll. P.J. Spangler (NMNH); 2 우, Clarke Hall, 11-20 Jan. 1965, coll. W.W. Wirth, Malaise trap (NMNH); 1 क, Clarke Hall, 21-31 Jan. 1965, coll. W.W. Wirth, Malaise trap (NMNH); 1 ô, Clarke Hall, 11-20 Feb. 1965, coll. W.W. Wirth, Malaise trap

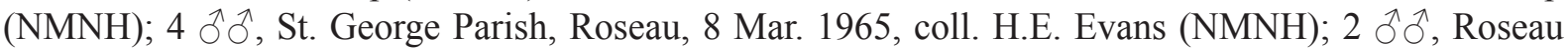
Valley, 9 Sep. 1937, coll. W. Richards (NHMUK); 1 đ̂, St. Luke Parish, S Chiltern, 2 Nov. 1966, coll. A.B. Gurney (NMNH); 1 \&, St. Patrick Parish, Grany Bay, 4 Sep. 1965, coll. D.L. Jackson (NMNH).

\section{Description}

\section{Male}

MeAsurements $(\mathrm{n}=4)$. Length 3.5-3.8 mm (mean = 3.7); head length 1.0-1.1 mm (mean = 1.1); head width $1.2 \mathrm{~mm}($ mean $=1.2)$; intertegular distance $0.7-0.8 \mathrm{~mm}($ mean $=0.7)$.

Colouration. Body blackish-brown, except as follows. Mandible yellow with red apex. Clypeus distal half dark brown. Flagellum with ventral surface dark reddish brown. Tegula dark yellowish brown. Wing membrane faintly dusky with dark setae, venation and pterostigma brown. Legs dark brown, except medio- and distitarsi and portions of metabasitarsus reddish brown.

Pubescence. Dull white. Sparse erect setae throughout, face below frons with tomentum partially obscuring clypeus, denser on lower paraocular area. Gena adjacent to eye with sparse tomentum.

SuRfaCE SCUlPTURe. Face polished, punctation fine. Clypeus punctation dense $(\mathrm{i}=1-1.5 \mathrm{pd})$. Supraclypeal area, lower and upper paraocular areas and frons densely punctate $(\mathrm{i} \leq \mathrm{pd})$. Ocellocular area sparsely punctate $(\mathrm{i}=1-2 \mathrm{pd})$. Gena and postgena polished, finely punctate-lineolate. Mesoscutum polished; punctation moderately coarse, finer laterally, relatively dense laterad of parapsidal lines $(i=1-1.5 \mathrm{pd})$, sparser on posterior and medial area of disc $(\mathrm{i}=1-3 \mathrm{pd})$; mesoscutellum similar. Metanotum rugulose. Preëpisternum reticulate rugulose. Hypoepimeral area finely rugulose. Mesepisternum below scrobe finely rugulose, with narrow smooth posterior margin. Metepisternum rugulose. Metapostnotum with longitudinal carinulae reaching $2 / 3$ distance to posterior margin, posterior margin smooth. Propodeum posterior and lateral surfaces smooth, with irregular sparse rugae. Metasomal terga polished, finely coriarious on apical impressed areas; punctation fine, present on basal portions ( $\mathrm{i}=1-2 \mathrm{pd})$, sparser $(\mathrm{i}=$ $1-4 \mathrm{pd}$ ) but distinct on T1; apical impressed areas impunctate. Metasomal sterna coriarious and finely, sparsely punctate $(i=2-4 \mathrm{pd})$.

STRUCTURE. Head round (length/width ratio $=0.85-0.86$ ). Eyes weakly convergent below. Clypeus $1 / 2$ below suborbital tangent. Frontal line deeply impressed below median ocellus. Gena narrower than eye. Hypostomal carinae subparallel. Occipital carina small but distinct. Pronotal dorsolateral angle orthogonal. Pronotal ridge carinate, interrupted by sulcus. Tegula ovoid. Submarginal cells three (1rs-m present), $2^{\text {nd }}$ submarginal cell posterior length approximately equal to anterior length of $3^{\text {rd }}$ submarginal 

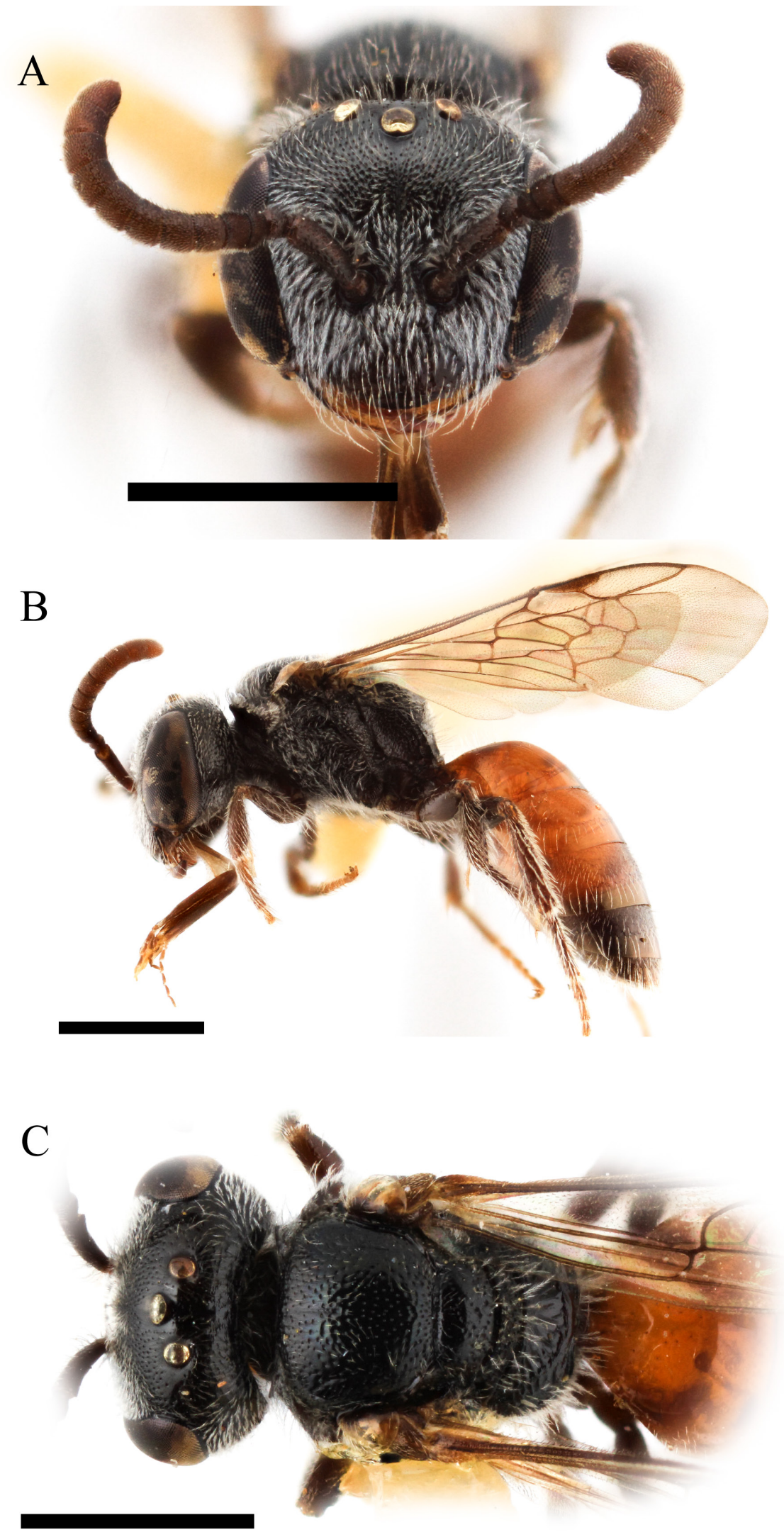

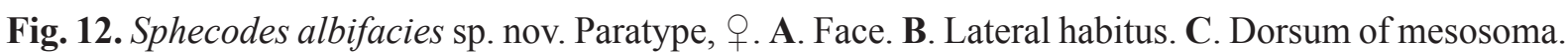
Scale bars $=1 \mathrm{~mm}$. 


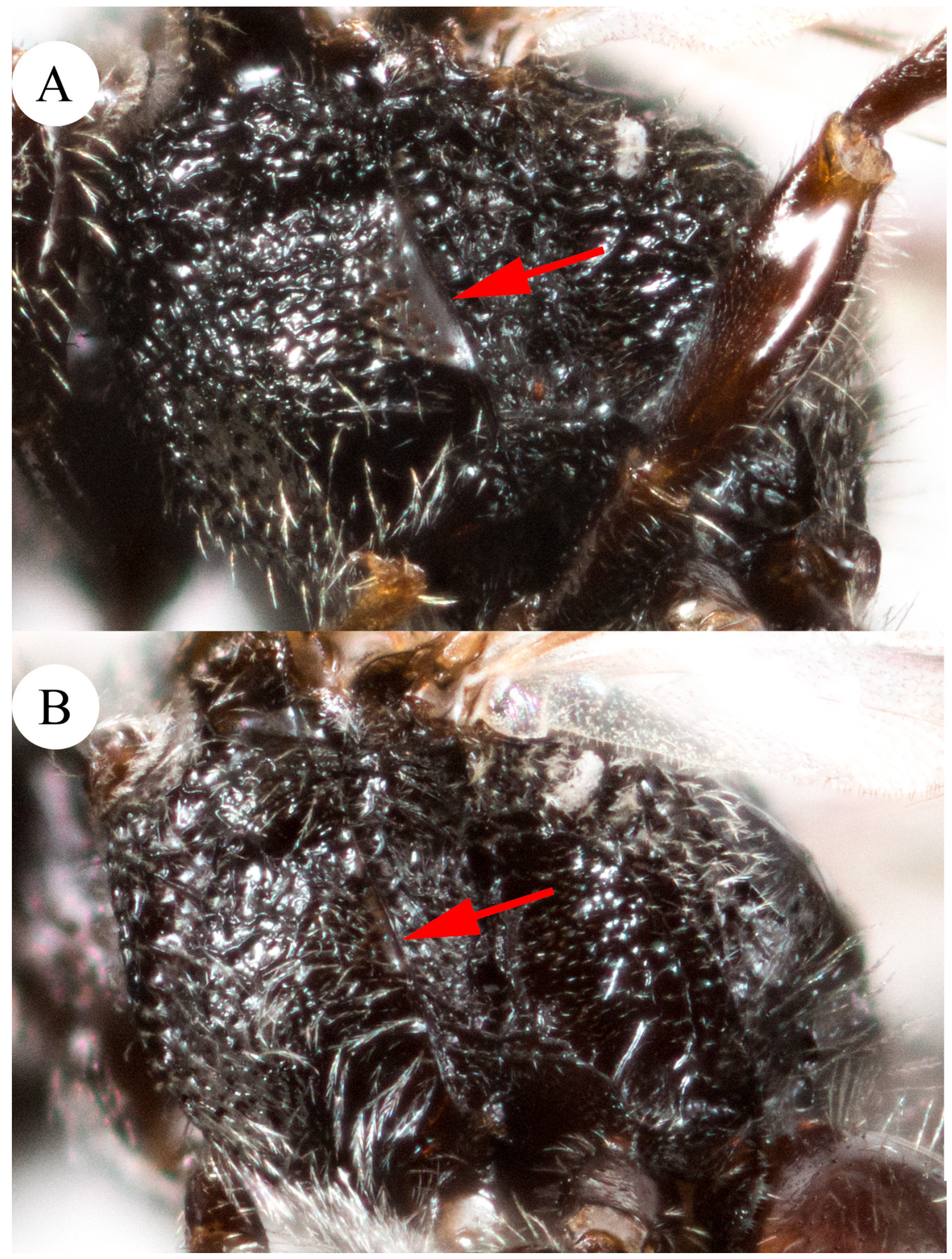

Fig. 13. Mesepisternum of species of Sphecodes Latreille, 1804 from Dominica. Arrows indicate smooth area on posterior margin. A. Sphecodes diablotinus sp. nov. B. S. albifacies sp. nov. 
cell. Distal hamuli arranged 2-2. $2^{\text {nd }}$ tarsal segment narrow at base, length as long as $3^{\text {rd }}$ tarsus. Propodeum with lateral carina reaching $2 / 3$ distance to dorsal margin; oblique carina fine.

Terminalia. As shown in Fig. 14C-D.

\section{Female}

MeAsurements $(\mathrm{n}=4)$. Length 3.7-4.1 mm (mean = 3.8); head length $1.1 \mathrm{~mm}($ mean $=1.1)$; head width $1.3-1.4 \mathrm{~mm}($ mean $=1.4)$; intertegular distance $0.8 \mathrm{~mm}($ mean $=0.8)$.

Colouration. Body blackish-brown, except as follows. Mandible yellow with red apex. Flagellum with ventral surface dark reddish brown. Tegula dark reddish brown. Wing membrane faintly dusky with dark setae, venation and pterostigma brown. Legs dark brown, except medio- and distitarsi and portions of metabasitarsus reddish brown. T1-T3 reddish orange, T4-T6 dark brown.

Pubescence. Dull white. Sparse erect setae throughout. Subappressed tomentum on the following: paraocular area below eye emargination, gena, pronotum dorsolateral angle, pronotal lobe, and preëpisternum. Mesofemur and mesotibia without pollen brush. Metafemur without scopa. Metatibia with thick setae on dorsal margin. Penicillis absent. Posterior propodeal surface with sparse short setae below longer erect setae. Metasomal sterna without scopa.

SURFACE SCULPTURE. Face polished, punctation fine. Clypeus punctation dense ( $\mathrm{i}=1-1.5 \mathrm{pd})$. Supraclypeal area, lower and upper paraocular areas and frons densely punctate $(\mathrm{i} \leq \mathrm{pd})$. Ocellocular area sparsely punctate $(\mathrm{i}=1-2 \mathrm{pd})$. Postgena polished, gena finely punctate-lineolate. Mesoscutum polished; punctation moderately coarse, relatively dense laterad of parapsidal lines $(i=1-1.5 \mathrm{pd})$, sparser on posterior and medial area of disc $(i=1-2 \mathrm{pd})$; mesoscutellum similar, submedial patch nearly impunctate. Metanotum rugulose. Preëpisternum reticulate rugulose. Hypoepimeral area finely rugulose. Mesepisternum below scrobe finely rugulose, with narrow, smooth posterior margin. Metepisternum rugulose. Metapostnotum with longitudinal carinulae reaching $2 / 3$ distance to posterior margin, posterior margin smooth. Propodeum posterior and lateral surfaces reticulate rugulose. T1-T2 polished, nearly impunctate, T3-T5 weakly coriarious, basal areas with very fine obscure punctation $(i=1-3 \mathrm{pd})$, virtually absent on $\mathrm{T} 1$; apical impressed areas impunctate. Metasomal sterna coriarious and finely, sparsely punctate $(i=2-4 \mathrm{pd})$.

StRUCTURE. Head wide (length/width ratio $=0.77-0.82$ ). Eyes weakly convergent below. Labrum broad, without apical projection or dorsal keel. Clypeus $1 / 2$ below suborbital tangent. Mandible simple, without preapical tooth. Gena narrower than eye. Hypostomal carinae subparallel. Occipital carina small but distinct. Flagellum 1 distinctly broader than long on dorsal surface, shorter than pedicel. Pronotal dorsolateral angle acute. Pronotal ridge carinate, interrupted by sulcus. Tegula ovoid. Submarginal cells three (1rs-m present), $2^{\text {nd }}$ submarginal cell narrow, posterior length slightly less than anterior length of $3^{\text {rd }}$ submarginal cell. Distal hamuli arranged 2-2. Inner metatibial spur minutely serrate. Basitibial plate indistinct, represented by minute glabrous spot. Metatarsus 2 narrow at base, length as long as metatarsus 3. Propodeum with lateral carina diverging dorsally, reaching $1 / 2$ distance to dorsal margin; oblique carina indistinct. T5 without evident pseudopygidial area, T6 with narrow pygidial plate.

\section{Remarks}

The holotype male of S. nigritus Ashmead, 1900 (NHMUK) was examined and found to have dense pubescence on the face, like $S$. albifacies sp. nov., but also a large smooth triangular area on the posterior mesepisternum. There does not yet seem to be any overlap in the halictid faunae of St. Vincent and the Grenadines (from where S. nigritus was described) and Dominica. There are only two other species of Sphecodes in the West Indies, both described from Cuba (Engel 2006b) and one of these, S. tainoi Engel, 2006, has subsequently been recorded from Puerto Rico (Engel \& Prado 2014). 


\section{A}

\section{$\mathrm{B}$}
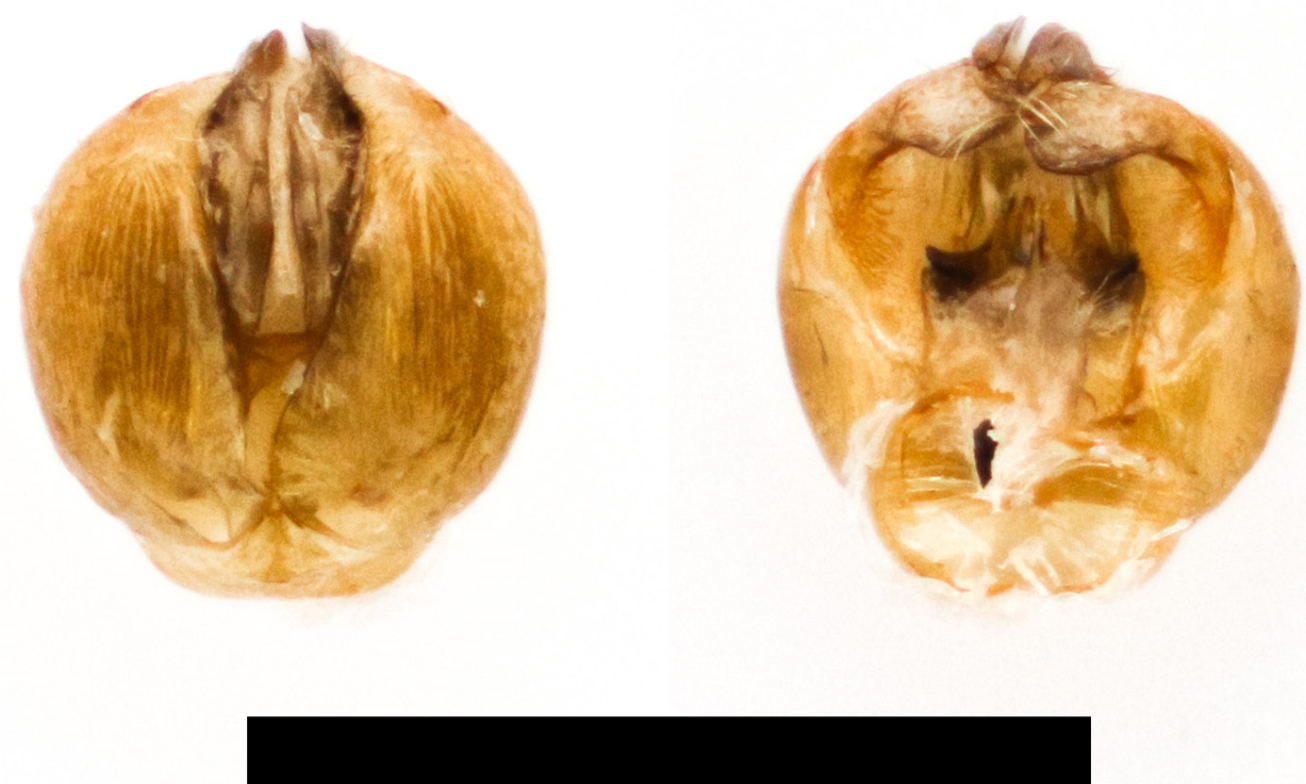

$\mathrm{C}$
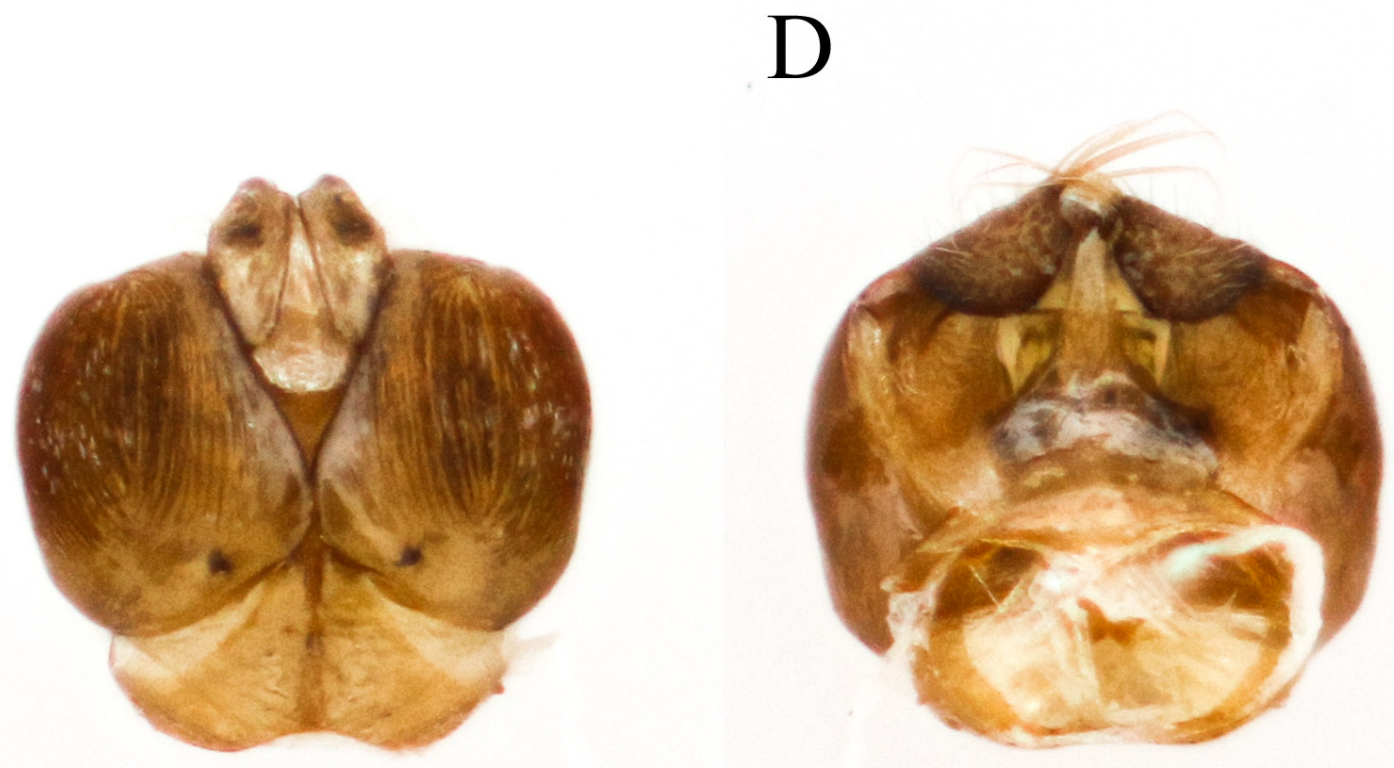

Fig. 14. - Genital capsule of Sphecodes diablotinus sp. nov. Paratype, Ô. A. Dorsal view. B. Ventral view. - Genital capsule of Sphecodes albifacies sp. nov. Paratype, Õ. C. Dorsal view. D. Ventral view. Scale bars $=1 \mathrm{~mm}$. 
Genus Microsphecodes Eickwort \& Stage, 1972

Sphecodes (Microsphecodes) Eickwort \& Stage, 1972: 501 (type species: Sphecodes kathleenae Eickwort, 1972, by original designation).

Microsphecodes dominicanus (Stage, 1972)

Figs $15 \mathrm{~A}-\mathrm{C}, 16 \mathrm{~A}-\mathrm{C}$

Sphecodes (Microsphecodes) dominicanus Stage in Eickwort \& Stage, 1972: 509, figs 17-27.

\section{Type locality}

DOMINICA: S Chiltern, 1600 ft., 19 Feb. 1965, coll. H.E. Evans (holotype, ô, NMNH).

\section{Material examined}

Type material

DOMINICA: 1 ô, paratype, St. Joseph Parish, Clarke Hall, Layou Valley, 4-7 Feb. 1965, coll. H.E. Evans (NMNH); 1 §, paratype, Clarke Hall, Layou Valley, 2-13 Mar. 1965, coll. H.E. Evans (NMNH).

\section{Other material}

DOMINICA: 1 \% , St. Paul Parish, ATR[E]C, Springfield, Fifi Trail, 'site 2', $15^{\circ} 21^{\prime}$ N, $61^{\circ} 22^{\prime}$ W, 442 m, 24 May-4 Jun. 2003, coll. T. Decker \& W. Wells, Malaise trap, voucher \#645 (TAMUIC).

\section{Description}

\section{Female}

Measurements $(\mathrm{n}=1)$. Length $3.4 \mathrm{~mm}$; head length $0.9 \mathrm{~mm}$; head width $1.1 \mathrm{~mm}$; intertegular distance $0.6 \mathrm{~mm}$.

Colouration. Head blackish-brown, except clypeal distal margin, labrum, mandible and anterior surface of scape testaceous. Flagellum dark reddish brown. Mesosoma including tegula and legs testaceous, except mesonotum reddish orange, mesoscutellum with dark brown patch. Wing membrane faintly dusky, with dark setae, venation and pterostigma dark brown. Metasoma testaceous, except apex of T1-T4 reddish orange, T5-T6 and apex of T4 dark brown.

Pubescence. Dull white. Sparse erect setae throughout. Subappressed tomentum on face below eye emargination. Mesofemur and mesotibia without pollen brush. Metafemur without scopa. Metatibia with thick setae on dorsal edge. Penicillis absent. Metasomal sterna without scopa.

SuRFACE SCULPTURE. Face polished, punctation fine. Clypeus punctation dense ( $\mathrm{i}=1-1.5 \mathrm{pd})$. Supraclypeal area, lower and upper paraocular areas and frons densely punctate $(\mathrm{i} \leq \mathrm{pd})$. Ocellocular area punctate $(\mathrm{i} \leq \mathrm{pd})$. Postgena weakly imbricate, gena finely punctate-lineolate. Mesoscutum polished; punctation moderately coarse, relatively dense laterad of parapsidal lines $(i=1-1.5 \mathrm{pd})$, sparser on posterior and medial area of disc $(i=1-3 \mathrm{pd})$; mesoscutellum similar. Metanotum rugulose. Preëpisternum reticulate rugulose. Hypoepimeral area finely punctate. Mesepisternum below scrobe finely rugulose, ventral half smooth. Metepisternum with longitudinal carinulae. Metapostnotum reticulate-rugose. Propodeum posterior and lateral surfaces reticulate rugulose. T1-T6 polished, T3-T5 weakly coriarious basally. Metasomal sterna coriarious and finely, sparsely punctate $(i=2-4 \mathrm{pd})$.

STRUCTURE. Head wide (length/width ratio $=0.8$ ). Eyes weakly convergent below. Labrum broad, without apical projection or dorsal keel. Clypeus $1 / 2$ below suborbital tangent. Mandible simple, without preapical tooth. Gena narrower than eye. Hypostomal carinae diverging towards mandible. F1 much broader than 

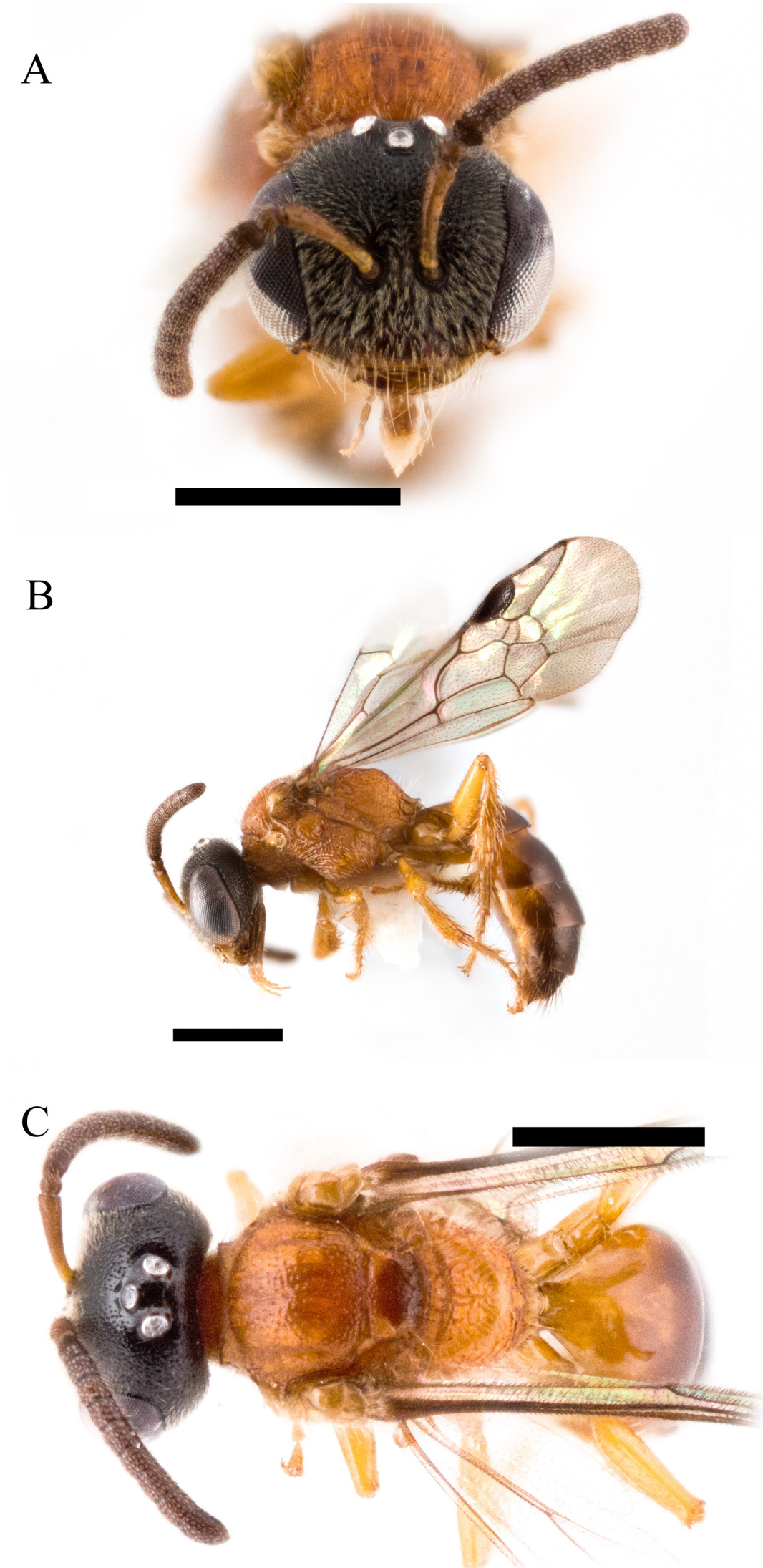

Fig. 15. Microsphecodes dominicanus (Stage, 1972), ․ A. Face. B. Lateral habitus. C. Dorsum of mesosoma. Scale bars $=1 \mathrm{~mm}$. 


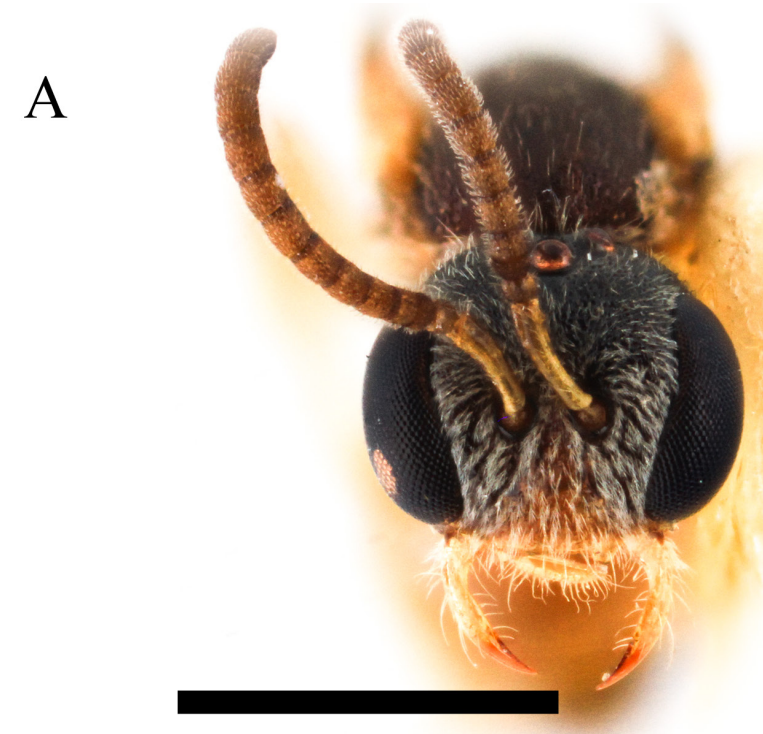

B

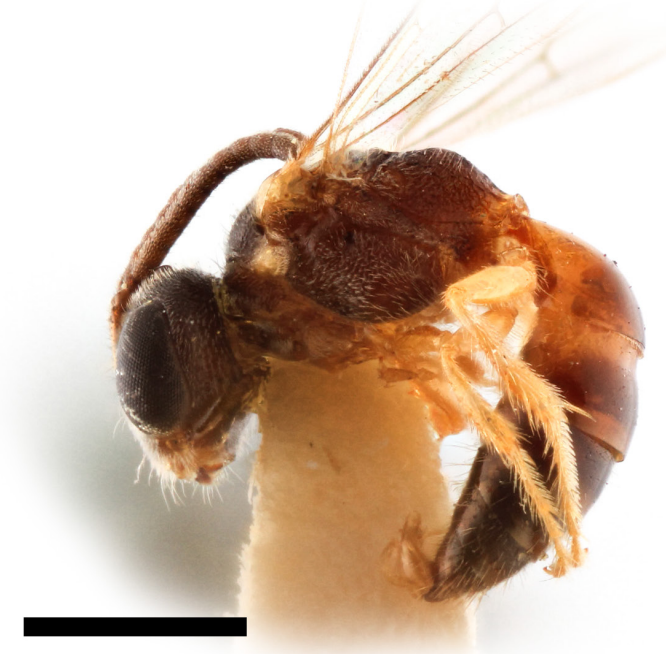

C

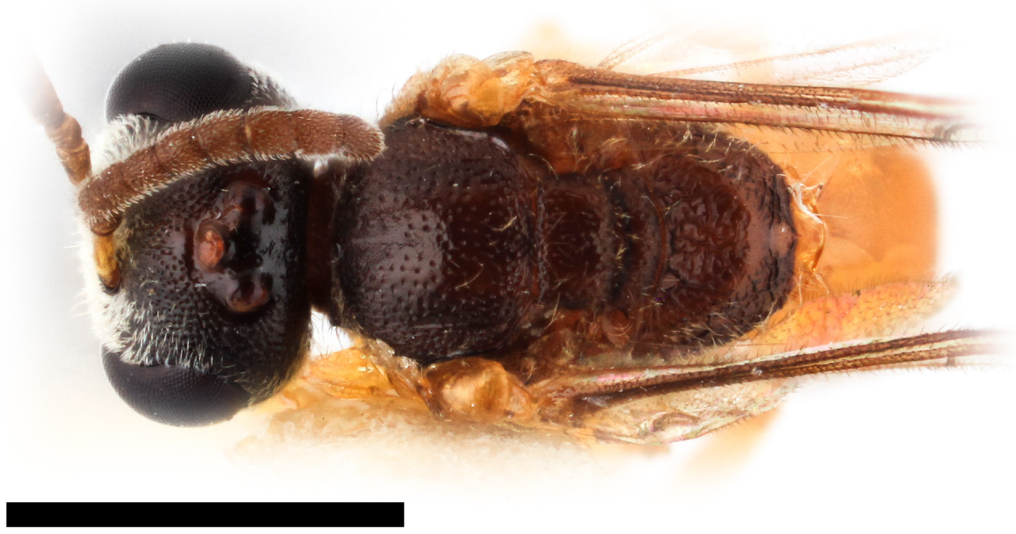

Fig. 16. Microsphecodes dominicanus (Stage, 1972). Paratype, §. A. Face. B. Lateral habitus. C. Dorsum of mesosoma. Scale bars $=1 \mathrm{~mm}$. 
long, shorter than pedicel. Pronotal dorsolateral angle acute. Pronotal ridge carinate, interrupted by sulcus. Tegula ovoid. Submarginal cells three (1rs-m present), $2^{\text {nd }}$ submarginal cell narrow, posterior length slightly less than anterior length of $3^{\text {rd }}$ submarginal cell. Distal hamuli arranged 2-2. Inner metatibial spur minutely serrate. Legs slender. Basitibial absent. Metatarsus 2 narrow at base, length as long as metatarsus 3 . Propodeum with lateral carina, reaching $1 / 2$ distance to dorsal margin; oblique carina fine. T5 without evident pseudopygidial area, T6 with narrow pygidial plate.

\section{Remarks}

The female of Microsphecodes dominicanus is described above for the first time. Both sexes can be distinguished easily from the two Sphecodes described above by the presence of yellow-testaceous colour on the legs and mesosoma (Figs 15B, 16B) and the reticulate rugae present on the metapostnotum and posterior propodeal surface (Figs 15C, 16C; see also Eickwort \& Stage 1972: figs 17-18). The host of M. dominicanus is unknown, but Microsphecodes are known to parasitize both Habralictus and Lasioglossum (Michener 1978; Michener et al. 1979). The single female specimen was collected at the same site as were seven specimens of $H$. gonzalezi and a single specimen of L. kalinago sp. nov., but L. dominicense sp. nov. is also known from nearby sites.

The use of Microsphecodes at the generic level is questionable. Sphecodes (Austrosphecodes) is evidently rendered paraphyletic by Microsphecodes based on molecular phylogenetic results (Habermannová et al. 2013). The implication of these results is that some or all Austrosphecodes should be synonymized with Microsphecodes. The latter name has priority, but if Austrosphecodes is treated at only the subgeneric level, then Microsphecodes should also be treated as a subgenus of Sphecodes. The current phylogenetic hypothesis would allow for Austrosphecodes and Microsphecodes combined to be treated at the generic level since together they form the sister group to other species included in the phylogeny (Habermannová et al. 2013). Full taxon sampling of major sphecodine groups has not been completed. The West Indian genus Nesosphecodes Engel, 2006, for example, also needs to be included in future studies of sphecodine bees. Until a more complete revision of the higher level systematics of the Sphecodini is completed, Microsphecodes is used as a genus following current usage (Michener 2007) despite the apparent synonymy.

Tribe Caenohalictini Michener, 1954

Genus Habralictus Moure, 1941

Habralictus Moure, 1941: 59 (type species: Habralictus flavopictus Moure, 1941, by original designation).

Zikaniella Moure, 1941: 57 (type species: Zikaniella crassiceps Moure, 1941, by original designation).

Habralictus antillarus sp. nov. urn:1sid:zoobank.org:act:0AF3E368-ACF0-4F9B-99AD-115866D1A12B

Figs $17 \mathrm{~A}-\mathrm{C}, 18 \mathrm{~A}-\mathrm{C}, 19 \mathrm{~A}-\mathrm{B}$

\section{Diagnosis}

Males of Habralictus antillarus sp. nov. can be distinguished from H. gonzalezi by head wide (length/ width ratio $=0.84-0.85$ ), clypeus with distal yellow maculation less than $1 / 5$ longitudinal length of clypeus (Fig. 18A), and gonostylus short, with numerous distinct setae (Fig. 19A-B). In H. gonzalezi males, the head is longer (length/width ratio $=0.95-0.96$ ), clypeal maculation is $1 / 3$ the longitudinal length of the clypeus (Fig. 21A; Gibbs 2012: fig. 8), and the gonostylus is long, clavate, with a single distinct seta (Gibbs 2012: figs 12-13). 


\section{A}

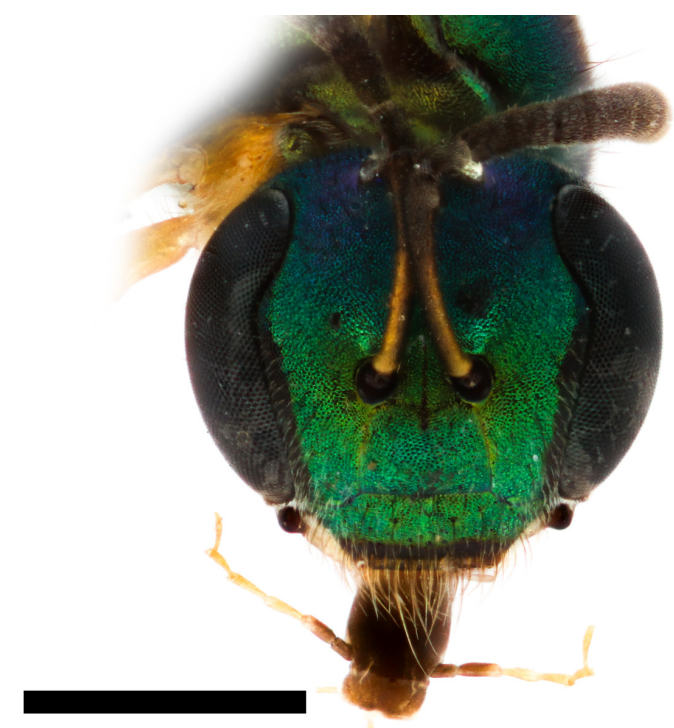

\section{B}
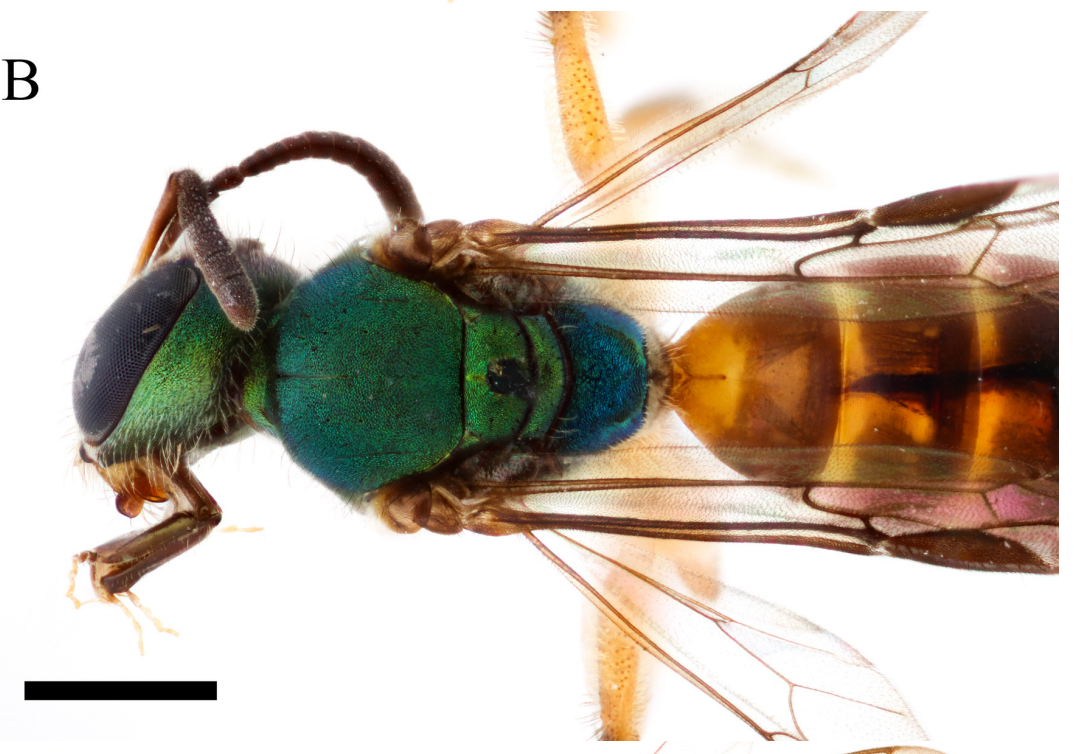

C

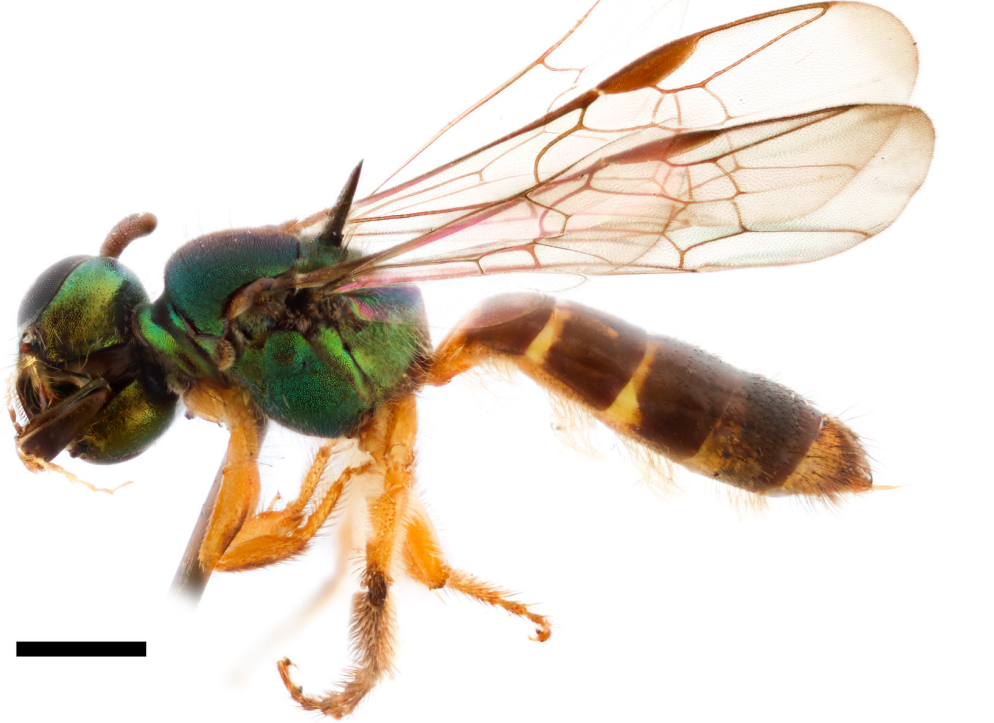

Fig. 17. Habralictus antillarus sp. nov. Paratype, q. A. Face. B. Lateral habitus. C. Dorsum of mesosoma. Scale bars $=1 \mathrm{~mm}$. 
Females of $H$. antillarus sp. nov. have a slightly wider head (length/width ratio $=0.90)$ and distal dark brown maculation of the clypeus is only $1 / 3$ the longitudinal length of the clypeus (Fig. 17A). In females of $H$. gonzalezi, the head is longer (length/width ratio $=0.92-0.97$ ) and the clypeal dark maculation is $1 / 2$ the longitudinal length of the clypeus (Fig. 20A). Furthermore, the dark integument of the lower paraocular area extends to the eye emargination in H. antillarus sp. nov. (Fig. 17A), but only to the lower margin of the antennal socket in H. gonzalezi (Fig. 20A; Gibbs 2012: fig. 2). Lasioglossum roseauense sp. nov. is superficially similar, but can be distinguished by generic characters such as the weak distal venation of the forewing, including the absence of 1rs-m (Fig. 8B).

\section{Type material}

\section{Holotype}

DOMINICA: §̋, St. George Parish, Freshwater Lake, 21 Jan. 1965, coll. W.W. Wirth, Bredin-Archbold Smithsonian Biodiversity Survey (NMNH).

\section{Paratypes}

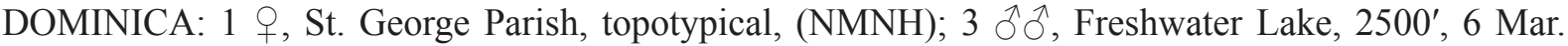
1965, coll. H.E. Evans (NMNH).

\section{Description}

\section{Female}

Measurements $(\mathrm{n}=1)$. Length $5.0 \mathrm{~mm}$; head length $1.2 \mathrm{~mm}$; head width $1.4 \mathrm{~mm}$; intertegular distance $0.9 \mathrm{~mm}$.

Colouration. Head and mesosoma iridescent golden-green, except as follows. Labrum brown. Mandible yellow with red apex. Clypeus distal margin dark brown. Antenna dark brown. Pronotal lobe brown. Tegula dark reddish brown. Wing membrane hyaline, with dark setae, venation and pterostigma brown. Legs yellow. Metasomal terga reddish brown, yellow basad of graduli.

Pubescence. Dull white to dark brown. Relatively sparse erect setae throughout, without tomentum, except on gena near eye, pronotal lobe and posterior surface of propodeum. Metasomal T1 anterior surface bare. T3 with sparse, erect dark setae. T4-T5 with very long dark setae, most evident laterally. Scopa well developed on hind leg and metasomal sterna, meso- and metatibia and tarsi with dark setae.

SuRfaCE SCUlPtURE. Head and mesosoma granular-tessellate, punctation indistinct. Metapostnotum medially with weak rugae, not reaching more than half distance to posterior margin, oblique carinulae on lateral portions extending to dorsolateral slope. Metasomal terga polished, T1-T2 virtually impunctate, T3 sparsely punctate $(i=3-6 \mathrm{pd}), \mathrm{T} 4$ sparsely punctate $(\mathrm{i}=2-4 \mathrm{pd})$, apical impressed areas impunctate, T1-T2 apical impressed areas impunctate except near lateral margins. Metasomal sterna smooth, piliferous punctures present on apical half $(\mathrm{i}=1-2.5 \mathrm{pd})$.

Structure. Head wide (length/width ratio $=0.90)$. Eyes weakly convergent below. Clypeus $2 / 3$ below suborbital tangent. Gena narrower than eye. Hypostomal carinae weakly divergent. Pronotal dorsolateral angle obtuse. Pronotal ridge rounded, interrupted by sulcus. Tegula ovoid. Submarginal cells three (1 rs-m present). Distal hamuli arranged 2-1-2. Inner metatibial spur pectinate, with 4 branches, proximal branch much longer than width of rachis. Metapostnotum narrowly rounded onto posterior propodeal surface; longitudinal length greater than apical width. Propodeum with lateral carina reaching less than $1 / 2$ distance to dorsal margin; oblique carina absent. Metasomal terga strongly reflexed laterally, metasoma appearing relatively flat. T2-T4 impressed areas medially about $1 / 2$ longitudinal length of basal area. 

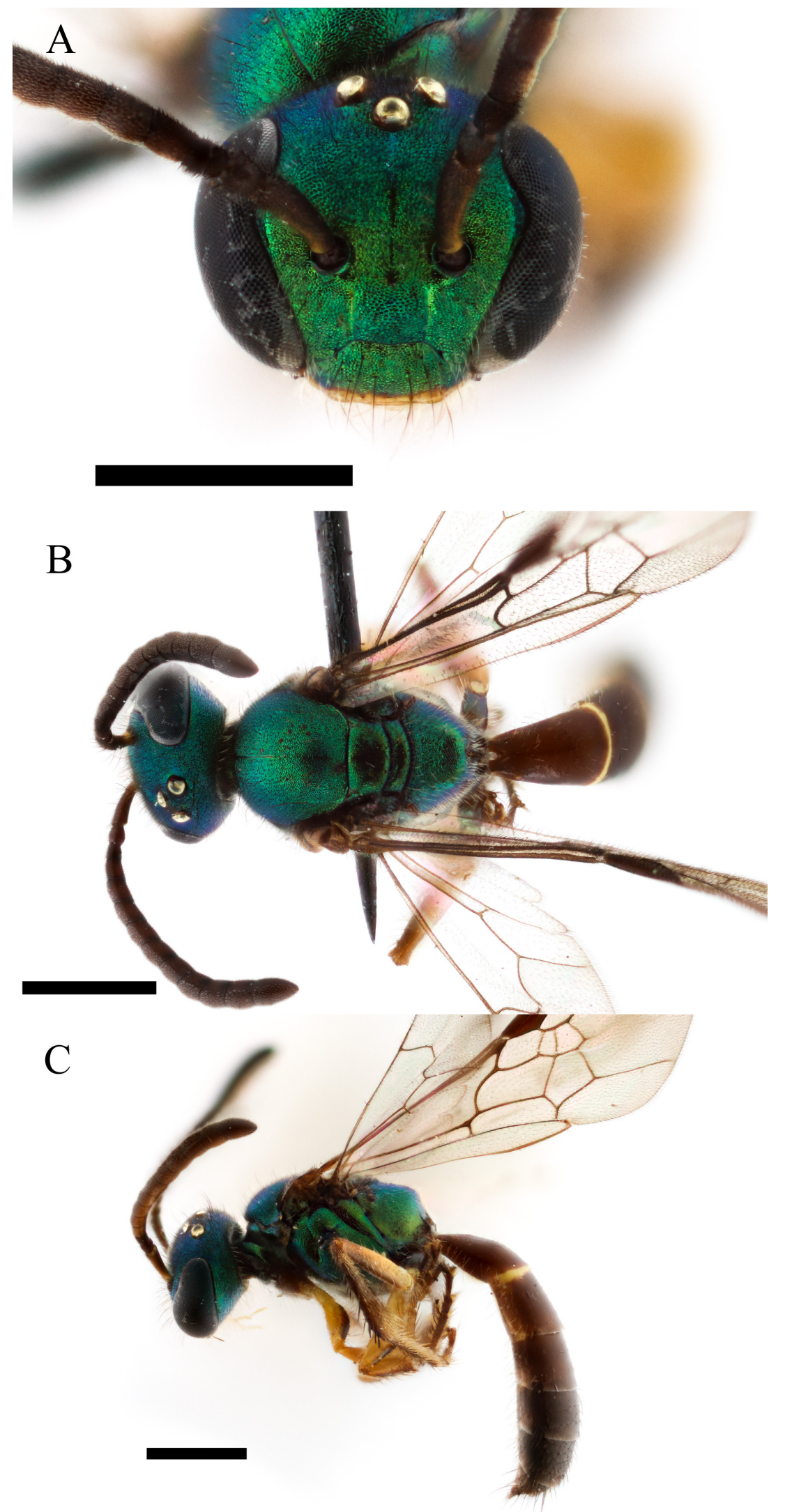

Fig. 18. Habralictus antillarus sp. nov. Holotype, O. A. Face. B. Lateral habitus. C. Dorsum of mesosoma. Scale bars $=1 \mathrm{~mm}$. 


\section{Male}

Measurements $(\mathrm{n}=3)$. Length 4.3-4.8 $\mathrm{mm}($ mean $=4.4)$; head length 0.9-1.3 mm (mean = 1.1); head width $1.1-1.5 \mathrm{~mm}($ mean $=1.3)$; intertegular distance $0.7-0.9 \mathrm{~mm}($ mean $=0.8)$.

Colouration. Similar to female except labrum yellow, clypeus distal margin very narrowly yellow, F2F11 reddish to yellowish brown ventrally, and metacoxa metallic.

Pubescence. Similar to female except scopa absent.

Surface SCULPTURE. Similar to female except punctation on T4 sparser $(i=4-8 \mathrm{pd})$.

Structure. Similar to female, with typical sexual differences. Head wide (length/width ratio $=0.84$ 0.85), eyes more distinctly convergent below. F2 length nearly $2 \times$ F1. Scape, pedicel and F1 reaching lower margin of median ocellus. Flagellomeres broadening towards apex. Inner metatibial spur simple, unbranched. Metasoma slender, widening towards T4-T5; not so strongly reflexed laterally. T2-T4 apical impressed areas less than $1 / 3$ of median length.

Terminalia. As shown in Fig. 19A-B. Gonostylus short, length and width subequal, with numerous long setae.

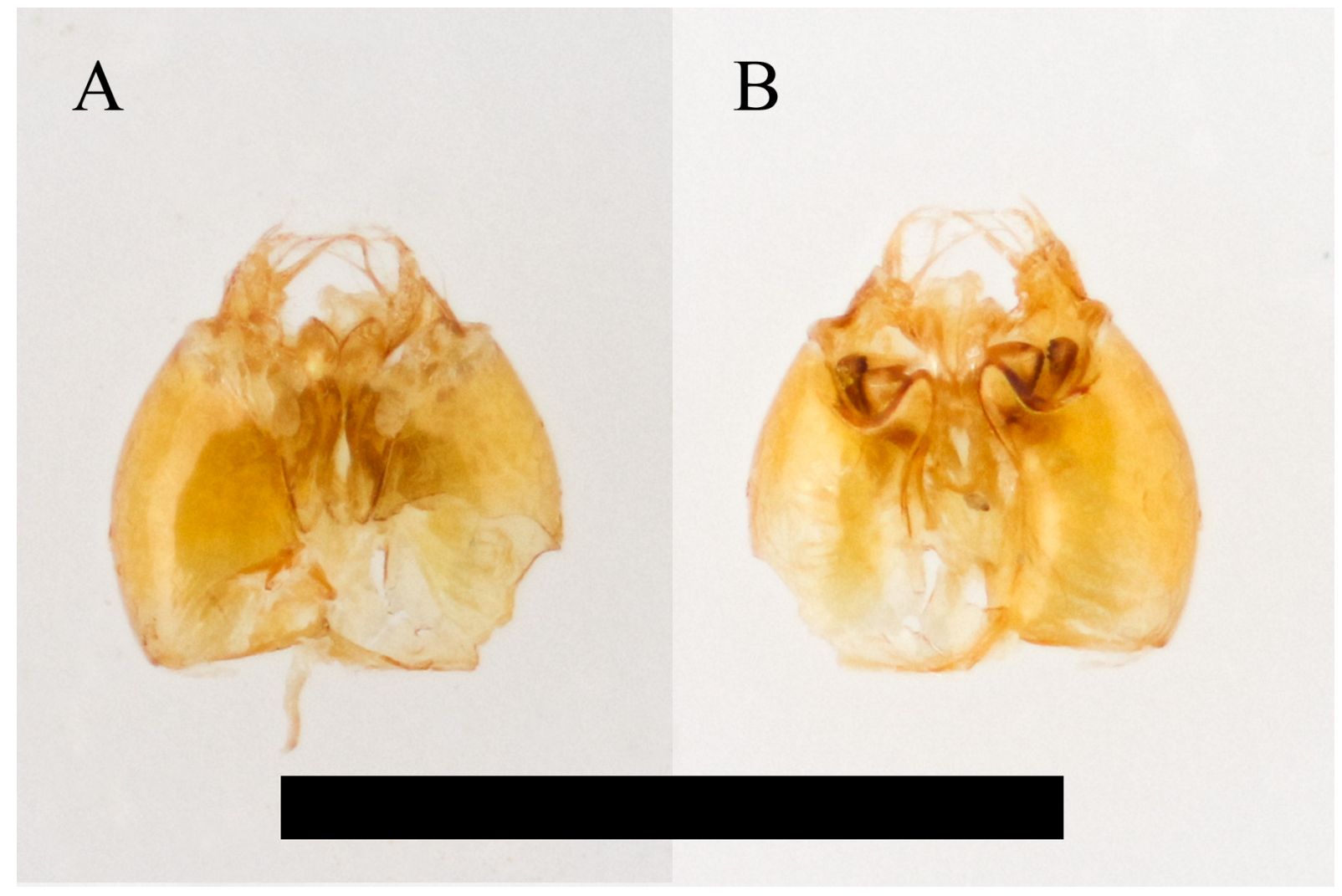

Fig. 19. Genital capsule of Habralictus antillarus sp. nov. Paratype, §̊. A. Dorsal view. B. Ventral view. Scale bar $=1 \mathrm{~mm}$. 
Habralictus gonzalezi Gibbs, 2012

Figs $20 \mathrm{~A}-\mathrm{C}, 21 \mathrm{~A}-\mathrm{C}$

Habralictus gonzalezi Gibbs, 2012: 3, figs 1-14.

\section{Material examined}

\section{Holotype}

DOMINICA: , , St. Paul Parish, "Parish of St. Joseph" [sic], Springfield Estate, $15.34667^{\circ}$ N, $61.3683^{\circ}$ W, 430 m, 15-20 Mar. 2003, coll. M.E. Irwin \& M. Shepard, Malaise trap (BBSL; the type series is from St. Paul Parish, collected at ATREC).

\section{Other material}

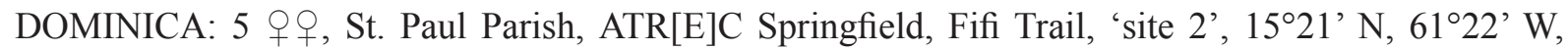
442 m, 24 May-4 Jun. 2003, coll. T. Decker \& W. Wells, Malaise trap, voucher \#645 (TAMUIC);

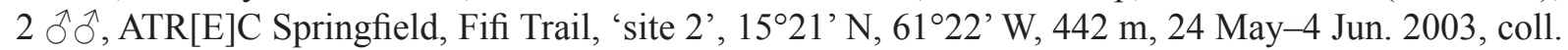
T. Decker \& W. Wells, Malaise trap (TAMUIC); 1 + , ATR[E]C Springfield, Fifi Trail, 'site 2', $15^{\circ} 21^{\prime}$ N, 61 ${ }^{\circ} 22^{\prime}$ W, 442 m, 24 May-4 Jun. 2003, coll. T. Decker \& W. Wells, yellow pan trap, voucher \#645

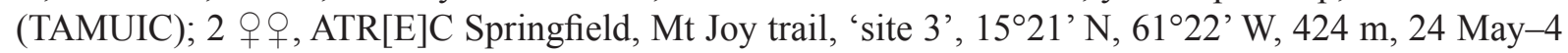
Jun. 2003, coll. T. Decker \& W. Wells, flight intercept trap, voucher \#645 (TAMUIC); 3 우, ATR[E]C Springfield, Mt Joy trail, 'site 5', $15^{\circ} 21^{\prime}$ N, $61^{\circ} 22^{\prime}$ 'W, 497 m, 28 May-4 Jun. 2003, coll. T. Decker \& W.

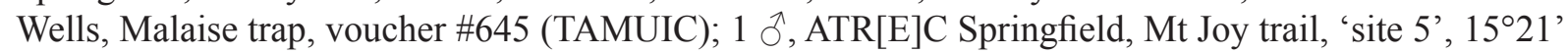
N, 612' W, 497 m, 28 May-4 Jun. 2003, coll. T. Decker \& W. Wells, Malaise trap (TAMUIC); 1 万,

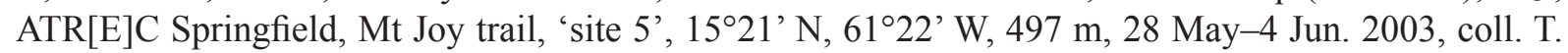
Decker \& W. Wells, flight intercept trap (TAMUIC).

\section{Remarks}

Habralictus gonzalezi is the most northerly distributed species of the genus known to occur in the Caribbean Islands. It can easily be distinguished from other bees on the island, except for $H$. antillarus sp. nov., by the various characters diagnostic for the tribe and genus (Michener 2007). The diagnosis provided for $H$. antillarus sp. nov. above can be used to distinguish these two species. The bright metallic colouration of the head and mesosoma (Figs 20C, 21C) will distinguish it from the dull metallic, black or testaceous colours of most of the halictine and sphecodine bees above. Lasioglossum roseauense sp. nov. is superficially similar, but the absence of vein 1rs-m (Fig.8) and the more distinct mesoscutal punctation (Fig. 8C) clearly differentiate it from $\mathrm{H}$. gonzalezi. Diagnostic characters, additional images and a key for discriminating this species from other Habralictus in the Lesser Antilles are available in the original description (Gibbs 2012).

Tribe Augochlorini Beebe, 1925

Genus Augochlora Smith, 1853

Subgenus Augochlora Smith, 1853

Augochlora Smith, 1853: 73 (type species: Halictus purus Say, 1837, by subsequent designation in Cockerell 1923: 448).

Oxystoglossa Smith, 1853: 83 (type species: Oxystoglossa decorata Smith, 1853, by monotypy).

Angochlora Schrottky, 1901: 213, lapsus calami.

Odontochlora Schrottky, 1909: 141 (type species: Augochlora mulleri Cockerell, 1900, by original designation).

Augochlora (Mycterochlora) Eickwort, 1969: 423 (type species: Halictus repandirostris Vachal, 1911, by original designation). 

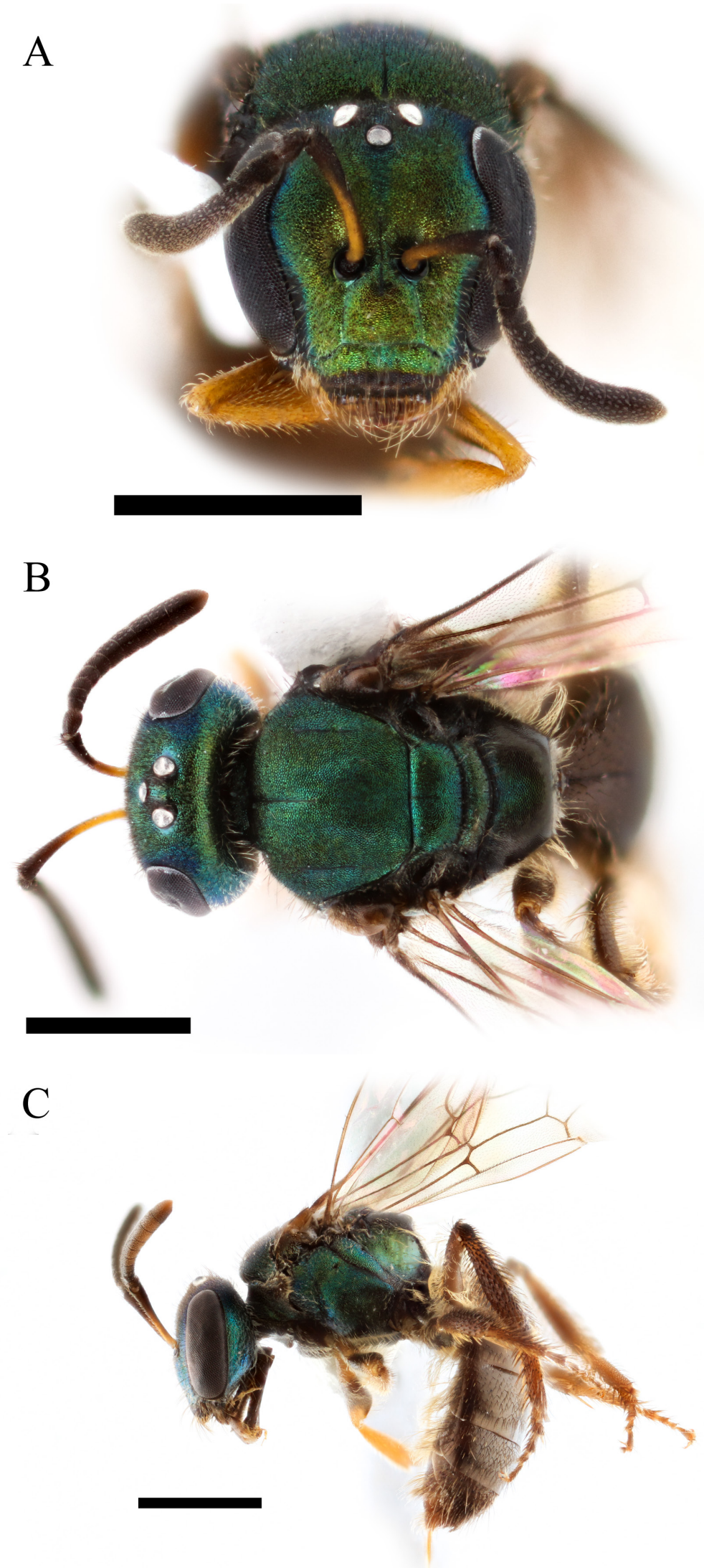

Fig. 20. Habralictus gonzalezi Gibbs, 2012, ․ A. Face. B. Lateral habitus. C. Dorsum of mesosoma. Scale bars $=1 \mathrm{~mm}$. 
A

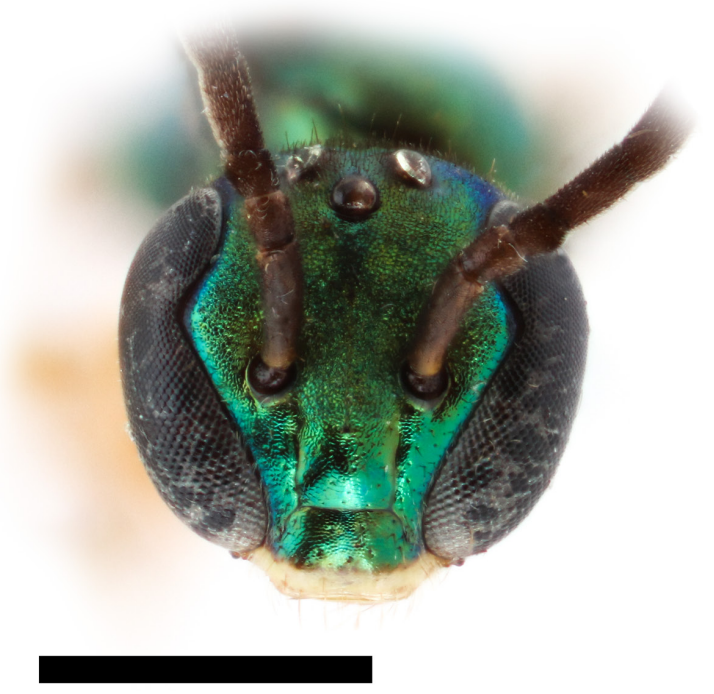

B

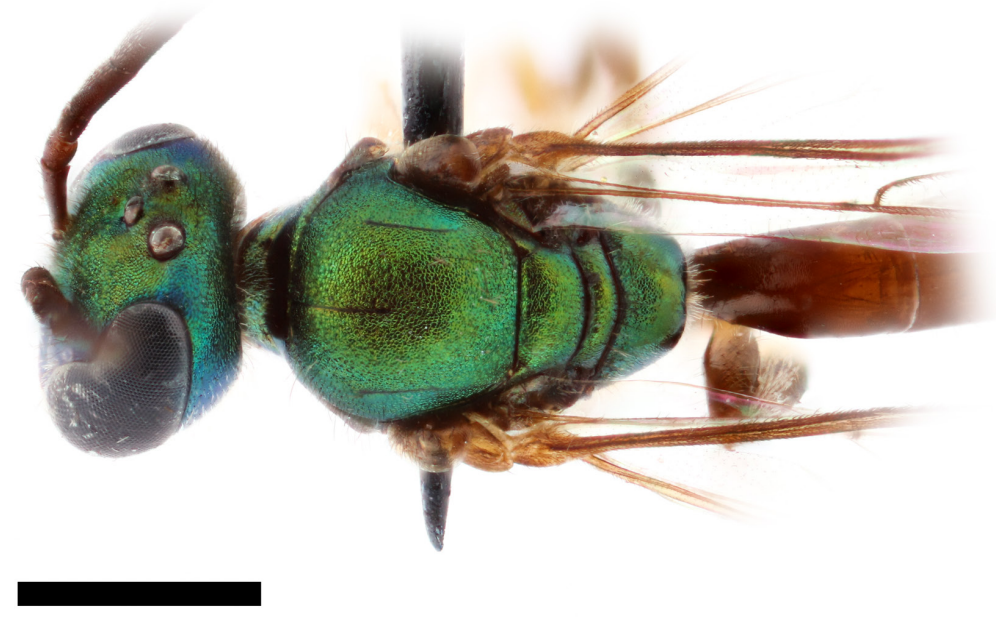

C

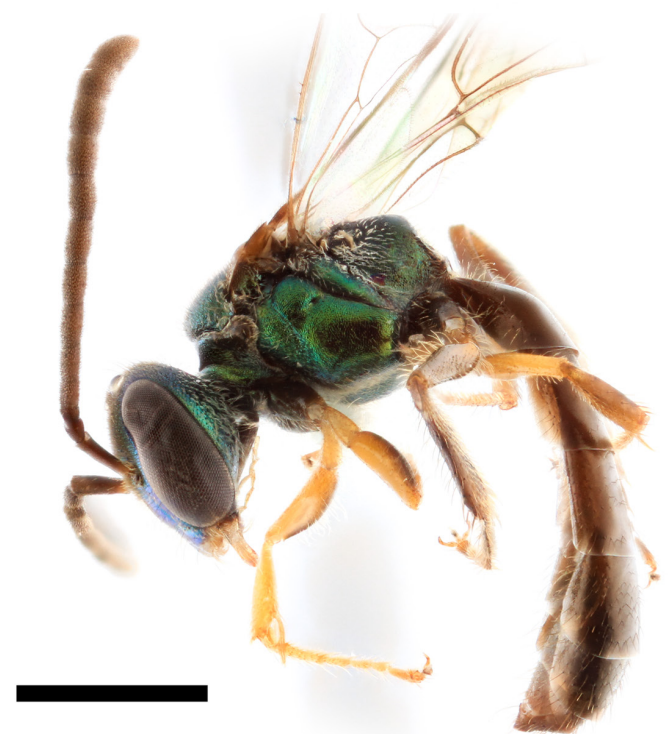

Fig. 21. Habralictus gonzalezi Gibbs, 2012, ふૈ. A. Face. B. Lateral habitus. C. Dorsum of mesosoma. Scale bars $=1 \mathrm{~mm}$. 
Augochlora (Augochlora) ignifera Crawford, 1914

Fig. 22A-C

Augochlora ignifera Crawford, 1914: 46.

\section{Type locality}

DOMINICA: Yale Expedition 1913, Jun. -Jul. 1913, coll. H.W. Foote, Cat. No. USNM 16734 (NMNH, holotype, + ).

\section{Remarks}

Augochlora ignifera is the only member of this genus and tribe currently known from the island, and it can easily be distinguished from other halictid bees on that basis. The female is particularly distinctive due to the fiery red iridescence covering most of the head, mesosoma and metasoma (Fig. 22A-C). The wings are faintly dusky. The male has a more coppery and greenish tone (Crawford 1914). The closest islands with a relatively well known halictid fauna are St. Vincent and the Grenadines. Six augochlorine bees are recorded from those islands (Ashmead 1900; Moure 2007). Future studies should compare A. ignifera to these species and others which presumably occur on intermediary islands but remain undocumented.

\section{Key to the Halictidae of Dominica}

1. Head and mesosoma lacking metallic reflections; female without scopa ......................2

- Head and mesosoma with metallic reflections; female with scopa ..........................4

2. Legs entirely orange-testaceous (Figs 15B, 16B); mesepisternum reddish to testaceous; marginal cell with basal fourth or less subtended by submarginal cells; metapostnotum completely covered in reticulate rugae (Figs 15C, 16C) .................Microsphecodes dominicanus (Stage, 1972)

- Legs mostly dark brown (Figs 9B, 10B, 11B, 12B); mesepisternum black; marginal cell with basal third or more subtended by submarginal cells; metapostnotum with longitudinal carinulae restricted to basal portion (Figs 9C, 10C, 11C, 12C) ................................

3. Male face mostly bare (Fig. 9A); female metasoma red on T1-T4 (Fig. 10B); both sexes with mesepisternum below scrobe with smooth triangular posterior area (Fig. 13A)

Sphecodes diablotinus sp. nov.

- Male face covered in white pubescence (Fig. 11A); female metasoma red on T1-T3 (Fig. 12B); both sexes with mesepisternum below scrobe with narrow smooth posterior margin (Fig. 13B)

Sphecodes albifacies sp. nov.

4. Metallic red colouration extending over entire body, distinctive on metasomal terga (Fig. 22B); female T5 with median longitudinal specialized area divided; male T7 without preapical carina forming false apex ............................Augochlora ignifera Crawford, 1914

- Metallic colouration limited to head and mesosoma; female T5 with median longitudinal specialized area not divided (may be absent); male T7 with preapical carina forming false apex

5. Head and mesosoma with granular microsculpture, mesoscutal punctation sparse and often obscure; metapostnotum without distinct rugae or carinulae covering most of the surface;

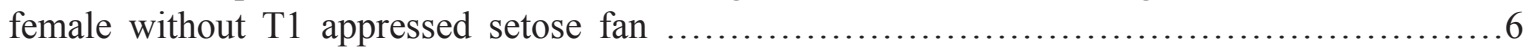

- Head and mesosoma with imbricate microsculpture; mesoscutal punctation dense at least laterally and distinct; metapostnotum with distinct rugae or carinulae covering most of the surface; female with $\mathrm{T} 1$ appressed setose fan 


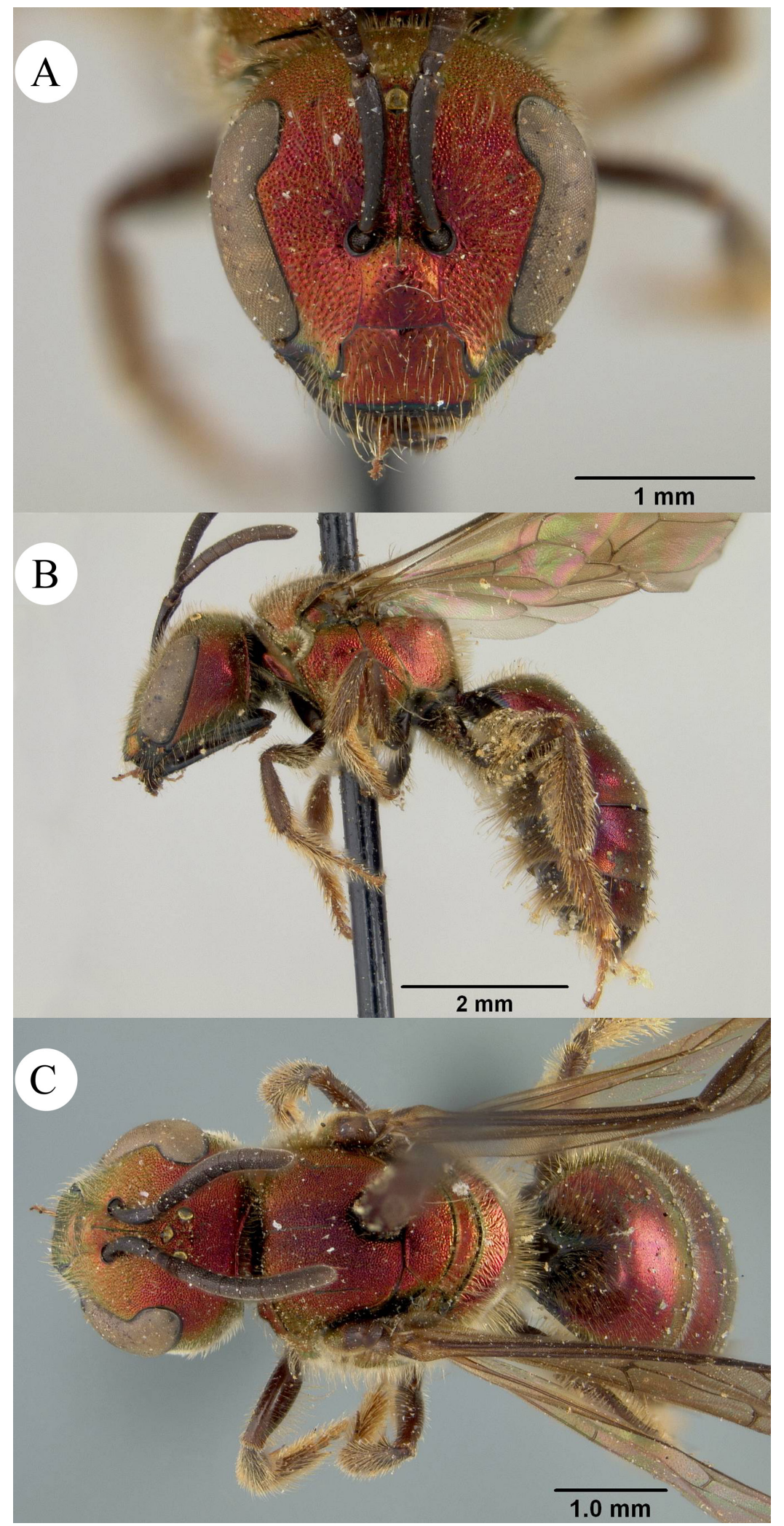

Fig. 22. Augochlora ignifera Crawford, 1914. Holotype, ․ A. Face. B. Lateral habitus. C. Dorsal habitus. Images of A. ignifera provided with the permission of the National Museum of Natural History, Smithsonian Institution, 10th and Constitution Ave. N.W., Washington, DC 20560-0193 (http://www. $\underline{\text { nmnh.si.edu/). }}$ 
6. Two submarginal cells (Fig. 8B); mesoscutal punctation sparse, but distinct; male unknown Lasioglossum roseauense sp. nov.

- Three submarginal cells; mesoscutal punctation obscure ..................................

7. Second and third submarginal cells weak; head longer than wide (length/width ratio $=1.02$; Fig. 7A); male unknown (antenna unlikely to be clavate)

Lasioglossum punctifrons (Crawford, 1914)

- Second and third submarginal cells strong; head usually wider than long (length/width ratio = 0.84-0.97); male with clavate antenna, slender T1-T2 (Figs 18B, 21B-C)

8. Clypeal yellow or dark brown distal maculation narrow (1/5 longitudinal distance in male, $1 / 3$ longitudinal distance in female) (Figs 17A, 18A); metapostnotum longitudinal length greater than apical width (Figs 17B, 18B); male head distinctly wider than long (length/width ratio $=0.84-0.85)($ Fig. 18A) .................................Habralictus antillarus $\mathrm{sp}$. nov.

- Clypeal yellow or dark brown distal maculation broad ( $1 / 3$ longitudinal distance in male, $1 / 2$ longitudinal distance in female) (Figs 20A, 21A); metapostnotum longitudinal length subequal to apical width (Figs 20B, 21B); male head narrower (length/width ratio $=0.95-0.96$ ) (Fig. 21A)

Habralictus gonzalezi Gibbs, 2012

9. Hypoepimeral area finely rugulose, without distinct punctures; mesepisternum below scrobe reticulate-rugulose; mesoscutal setae a mix of brown and dull white; male unknown

Lasioglossum kalinago sp. nov.

- Hypoepimeral area smooth, with distinct punctures; mesepisternum below scrobe punctate; mesoscutal setae dull white 10

10. Head short (length/width ratio $=0.9$; Figs $2 \mathrm{~A}, 3 \mathrm{~A})$; smaller in size (body length $\sim 4 \mathrm{~mm}$ ) $\ldots \ldots$ Lasioglossum dominicense sp. nov.

- Head longer (length/width ratio $=1.0$; Figs 5A, 6A); larger in size (body length $\sim 5 \mathrm{~mm}$ ) $\ldots \ldots$ Lasioglossum kilpatrickae sp. nov.

\section{Discussion}

Bees are widely recognized as the most important animal pollinators of wildflowers and agricultural crops (Brown \& Paxton 2009). Reports of pollinator declines have led to increased interest in bees, yet there remains limited knowledge of bee taxonomy for many regions. This lack of understanding is due to a dearth of taxonomic expertise and revisionary studies. For the most species-rich genus of bee, Lasioglossum, revisions remain largely incomplete for North America, with the exception of Lasioglossum s. s. and L. (Leuchalictus) (McGinley 1986), L. (Dialictus) for Canada and the eastern USA (Gibbs 2010, 2011), and L. (Hemihalictus s.l.) and L. (Sphecodogastra s.l.) for eastern North America and, in part, the West (Gibbs et al. 2013; McGinley 2003). Many North American species of this abundant taxon still await description.

The halictid fauna of the West Indies has been poorly studied in the past, likely due to the perceived difficulty of the group and the lack of general interest in such a depauperate bee fauna. Studies of West Indian halictid bees, particularly in the Greater Antilles, were initiated by George C. Eickwort (Eickwort 1988), before his untimely death in Jamaica (Wcislo et al. 1994). More recently, there has been a limited number of studies in the region, but most of these have been haphazard descriptions of only one or a few species (e.g., Engel 2011; Gibbs 2012), which provide limited context to understanding the broader diversity of the islands, or have been checklists which do not include coverage of halictid bees (Meurgey 2014). To begin to resolve this lack of understanding, a complete survey of all halictid bees from 
Dominica has been provided herein. Prior to this work, the halictid bee fauna of Dominica went largely unstudied for more than a century. There are no described halictid bees reported from several islands in the West Indies (e.g., Montserrat, Martinique, Guadeloupe, St. Lucia, Antigua and Barbuda), but this is due to a lack of sampling and taxonomic studies in the area rather than true absence. Additional studies of other regions in the West Indies are underway (J. Gibbs, unpublished data; A. Pauly, in litt.) as steps towards a more complete understanding of the regional bee fauna.

\section{Acknowledgements}

Material used in this study was made available through generous loans of specimens from Brian Harris and Seán Brady (NMNH), Terry Griswold (BBSL), Kevin Williams (FSCA), David Notton (NHMUK), Eli Wyman and Jerry Rozen (AMNH) and Ed Riley (TAMUIC). Additional loans from other institutions provided the comparative material necessary to understand the fauna of adjacent islands. Alain Pauly generously provided specimens from Martinique for comparison. Shelby Kilpatrick (TAMUIC) collected material for this study while traveling in Dominica. Post-doctoral support for the author was made available by funding from the USDA Specialty Crop Research Initiative (2012-51181-20105). Imaging equipment was purchased with funds from MSU Project GREEEN \#GR14-053. I thank two anonymous reviewers for their helpful comments on the manuscript.

\section{References}

Ascher J.S. \& Pickering J. 2015. Discover Life Bee Species Guide and World Checklist (Hymenoptera: Apoidea: Anthophila). Draft-41. Available from http://www.discoverlife.org/mp/20q?guide=Apoidea species [accessed 22 Jan. 2016]

Ashmead W.H. 1900. VI. Report upon the aculeate Hymenoptera of the islands of St. Vincent and Grenada, with additions to the parasitic Hymenoptera and a list of the described Hymenoptera of the West Indies. Transactions of the Royal Entomological Society of London 48 (2): 207-367. http://dx.doi. org/10.1111/j.1365-2311.1900.tb02379.x

Baker C.F. 1906. Halictinae de Cuba. In: Earle F.S. (ed.) Primer Informe de la Estacion Central Agronomica: 253-274. Ruiz y Hermano, Havana.

Beebe W. 1925. Studies of a tropical jungle; one quarter of a square mile of jungle at Kartabo, British Guiana. Zoologica 6: 5-193.

Blüthgen P. 1823. Beiträge zur Kenntnis der Bienengattung Halictus Latr. Archiv für Naturgeschichte, Abteilung A 89: 232-332.

Brown M.J.F. \& Paxton R.J. 2009. The conservation of bees: a global perspective. Apidologie 40: 410416. http://dx.doi.org/10.1051/apido/2009019

Brullé G.A. 1840. Insectes. In: Barker-Webb M.P. \& Berthelot S. (eds) Histoire Naturelle des Iles Canaries, Vol. 2, Part 2: 55-95. Béthune, Paris. Available from http://biodiversitylibrary.org/ page/41308628 [accessed 29 Feb. 2016]

Buysson R. 1900. Sur quelques hyménoptères de Madagascar. Annales de la Société Entomologique de France 69: 177-180. Available from http://biodiversitylibrary.org/page/8249711 [accessed 29 Feb. 2016]

Cockerell T.D.A. 1900. Descriptions of new bees collected by Mr. H.H. Smith in Brazil. I. Proceedings of the Academy of Natural Sciences 52: 356-377. Available from http://biodiversitylibrary.org/ page/24694236 [accessed 29 Feb. 2016] 
Cockerell T.D.A. 1923. XLIII. Some bees from British Guiana. Annals and Magazine of Natural History 9: 442-459. http://dx.doi.org/10.1080/00222932308632869

Crawford J.C. 1914. Hymenoptera, superfamilies Apoidea and Chalcidoidea, of the Yale Dominican expedition of 1913. Proceedings of the United States National Museum 47: 131-134. Available from http://biodiversitylibrary.org/page/7762803 [accessed 29 Feb. 2016]

Curtis J. 1933. British Entomology; being Illustrations and Descriptions of the Genera of Insects found in Great Britain and Ireland: ... Vol. X. Privately published, London.

Danforth B.N., Brady S.G., Sipes S.D. \& Pearson A. 2004. Single-copy nuclear genes recover Cretaceousage divergences in bees. Systematic Biology 53:309-326. http://dx.doi.org/10.1080/10635150490423737

Ducke A. 1902. Ein neues Subgenus von Halictus Latr. Zeitschrift für Systematische Hymenopterologie und Dipterologie 2: 102-103. Available from http://biodiversitylibrary.org/page/13367938 [accessed 29 Feb. 2016]

Eickwort G.C. 1969. A comparative morphological study and generic revision of the augochlorine bees (Hymenoptera: Halictidae). University of Kansas Science Bulletin 48: 325-524. Available from http:// biodiversitylibrary.org/page/3279444 [accessed $29 \mathrm{Feb} .2016$ ]

Eickwort G.C. 1988. Distribution patterns and biology of West Indian sweat bees (Hymenoptera: Halictidae). In: Liebherr J.K. (ed.) Zoogeography of Caribbean Insects: 232-253. Cornell University Press, Ithaca, New York.

Eickwort G.C. \& Stage G.I. 1972. A new subgenus of Neotropical Sphecodes cleptoparasitic upon Dialictus (Hymenoptera: Halictidae, Halictinae). Journal of the Kansas Entomological Society 45: 500515.

Engel M.S. 2001a. A monograph of the Baltic amber bees and evolution of the Apoidea (Hymenoptera). Bulletin of the American Museum of Natural History 259: 1-192.

Engel M.S. 2001b. Three new Habralictellus bee species from the Caribbean (Hymenoptera: Halictidae). Solenodon 1: 33-37.

Engel M.S. 2006a. A new species of Microsphecodes from St. Kitts (West Indies) (Hymenoptera: Halictidae). Mitteilungen des Internationalen Entomologischen Vereins 31: 51-54.

Engel M.S. 2006b. The Sphecodes of Cuba (Hymenoptera: Halictidae). Acta Zoologica Cracoviensia 49B: 73-78. http://dx.doi.org/10.3409/000000006783995355

Engel M.S. 2011. A new species of Dialictus from Sombrero Island, Anguilla (Hymenoptera, Halictidae). ZooKeys 86: 61-68. http://dx.doi.org/10.3897/zookeys.86.909

Engel M.S. \& Prado S.G. 2014. First record of the cleptoparasitic bee genus Sphecodes from Puerto Rico (Hymenoptera: Halictidae). Journal of Melittology 39: 1-6. http://dx.doi.org/10.17161/jom.v0i39.4781

Erichson W.F. 1835. Beschreibung von 19 neuen Hymenopteren aus Andalusien. In: Waltl J. (ed.) Reise durch Tyrol, Oberitalien und Piemont nach dem südlichen Spanien, nebst einem Anhange zoologischen Inhalts (Über die Thiere Andalusiens): 101-109. Verlag der Pustet'schen Buchhandlung (J.F. Winkler), Passau, Germany.

Evans H.E. 1972. Bredin-Archbold-Smithsonian Biological Survey of Dominica: aculeate wasps (Hymenoptera: Scolioidea, Vespoidea, Pompiloidea, Sphecoidea). Smithsonian Contributions to Zoology 115: 1-19. http://dx.doi.org/10.5479/si.00810282.115

Fabricius J.C. 1793. Entomologia Systematica Emendata et Aucta. Secundum Classes, Ordines, Genera, Species Adjectis Synonymis, Locis, Observationibus, Descriptionibus, Vol. 2. Proft, Copenhagen. 
Fabricius J.C. 1804. Systema Piezatorum Secundum Ordines, Genera, Species Adiectis Synonymis, Locis, Observationibus, Descriptionibus. Reichard, Braunschweig.

Friese H. 1909. Die Bienenfauna von Neu-Guinea. Annales Musei Nationalis Hungarici 7: 179-288.

Genaro J.A. \& Franz N.M. 2008. The bees of greater Puerto Rico (Hymenoptera: Apoidea: Anthophila). Insecta Mundi 40: 1-24.

Gibbs J. 2009a. Integrative taxonomy identifies new (and old) species in the Lasioglossum (Dialictus) tegulare (Robertson) species group (Hymenoptera, Halictidae). Zootaxa 2032: 1-38.

Gibbs J.J. 2009b. New species in the Lasioglossum petrellum species group identified through an integrative taxonomic approach. The Canadian Entomologist 141: 371-396.

Gibbs J. 2010. Revision of the metallic species of Lasioglossum (Dialictus) in Canada (Hymenoptera, Halictidae, Halictini). Zootaxa 2591: 1-382.

Gibbs J. 2011. Revision of the metallic Lasioglossum (Dialictus) of eastern North America (Hymenoptera: Halictidae: Halictini). Zootaxa 3073: 1-216.

Gibbs J. 2012. A new species of Habralictus Moure from Dominica, Lesser Antilles (Hymenoptera, Halictidae). ZooKeys 168: 1-12. http://dx.doi.org/10.3897/zookeys.168.2524

Gibbs J., Packer L., Dumesh S. \& Danforth B.N. 2013. Revision and reclassification of Lasioglossum (Evylaeus), L. (Hemihalictus) and L. (Sphecodogastra) in eastern North America (Hymenoptera: Apoidea: Halictidae). Zootaxa 3672: 1-117. http://dx.doi.org/10.11646/zootaxa.3672.1.1

Habermannová J., Bogusch P. \& Straka J. 2013. Flexible host choice and common host switches in the evolution of generalist and specialist cuckoo bees (Anthophila: Sphecodes). PloS ONE 8: e64537. http:// dx.doi.org/10.1371/journal.pone.0064537

Harris R.A. 1979. A glossary of surface sculpturing. Occasional Papers in Entomology 28: 1-31.

Hook A.W., Neff J.L., Engel M.S. \& Court H. 2014. The Apoidea (Hymenoptera) fauna of Little Tobago Island, West Indies. Journal of the Kansas Entomological Society 87: 242-244. http://dx.doi. org/10.2317/JKES130910.1

Illiger K. 1806. William Kirby's Familien der bienenartigen Insekten mit Zusätsen, Nachweisungen und Bemerkungen. Magazin für Insektenkunde 5: 28-175. Available from http://biodiversitylibrary.org/ page/43036970 [accessed 29 Feb. 2016]

Kirby W. 1802. Monographia Apum Angliae; or, an Attempt to Divide into their Natural Genera and Families, such Species of the Linnean Genus Apis as have been Discovered in England ... Vol. 2. Privately published, Ipswich, UK.

Latreille P.A. 1804. Tableau méthodique des Insectes. In: Deterville J.-F. (ed.) Nouveau Dictionnaire d'Histoire naturelle: 129-200. Crapelet, Paris.

Linnaeus C. 1758. Systema Naturae per Regna Tria Naturae, Secundum Classes, Ordines, Genera, Species, cum Characteribus, Differentiis, Synonymis, Locis. Vol. I. $10^{\text {th }}$ edition. Salvius, Stockholm.

Mavromoustakis G.A. 1948. On the bees (Hymenoptera Apoidea) of Cyprus.-Part I. Annals and Magazine of Natural History, Series 121 (8): 541-587. http://dx.doi.org/10.1080/00222934808653931

McGinley R.J. 1986. Studies of Halictinae (Apoidea: Halictidae), I: Revision of New World Lasioglossum Curtis. Smithsonian Contributions to Zoology 429: 1-294. http://dx.doi.org/10.5479/si.00810282.429

McGinley R.J. 2003. Studies of Halictinae (Apoidea: Halictidae), II: Revision of Sphecodogastra Ashmead, floral specialists of Onagraceae. Smithsonian Contributions to Zoology 610: 1-55. http:// dx.doi.org/10.5479/si.00810282.610 
Meurgey F. 2014. Liste préliminaire des abeilles de Guadeloupe (Petites Antilles) et leurs relations avec la flore butinée (Hymenoptera: Apoidea, Megachilidae et Apidae). Annales de la Société entomologique de France, New Series 50: 89-110.

Michener C.D. 1954. Bees of Panamá. Bulletin of the American Museum of Natural History 104: 1-175.

Michener C.D. 1978. The parasitic groups of Halictidae. University of Kansas Science Bulletin 51: 291-339. Available from http://biodiversitylibrary.org/page/13448210 [accessed 29 Feb. 2016]

Michener C.D. 2007. The Bees of the World. $2^{\text {nd }}$ editon. The Johns Hopkins University Press, Baltimore.

Michener C.D., Breed M.D. \& Bell W.J. 1979. Seasonal cycles, nests, and social behavior of some Colombian halictine bees (Hymenoptera; Apoidea). Revista de Biologia Tropical 27: 13-34.

Moure J.S. 1941. Apoidea Neotropica - III. Arquivos do Museu Paranaense 1: 41-99.

Moure J.S. 1947. Novos agrupamentos genéricos e algumas espécies novas de abelhas sulamericanas. Museu Paranaense Publicações Avulsas 3: 1-37.

Moure J.S. 2001. Uma pequena abelha com cabeça e mandíbulas excepcionais (Hymenoptera, Halictidae). Revista Brasileira de Zoologia 18: 493-497.

Moure J.S. 2007. Halictini Thomson, 1869. In: Moure J.S., Urban D. \& Melo G.A.R. (eds) Catalogue of Bees (Hymenoptera, Apoidea) in the Neotropical Region: 823-870. Sociedade Brasileira de Entomologia, Curitiba, Brazil.

Moure J.S. \& Hurd P.D. 1982. On two new groups of Neotropical halictine bees (Hymenoptera, Apoidea). Dusenia 23: 46.

Patton W.H. 1880. Two new bees of the genus Sphecodes. The American Entomologist 1: 230.

Pauly A. 1984. Classification des Halictidae de Madagascar et des îles voisines I. Halictinae (Hymenoptera Apoidea). Verhandlungen der Naturforschenden Gesellschaft in Basel 94: 121-156.

Pesenko Y.A. 2007. Subgeneric classification of the Palaearctic bees of the genus Evylaeus Robertson (Hymenoptera: Halictidae). Zootaxa 1500: 1-54.

Robertson C. 1890. New North American bees of the genera Halictus and Prosopis. Transactions of the American Entomological Society 17: 315-318. Available from http://biodiversitylibrary.org/ page/7491165 [accessed 29 Feb. 2016]

Robertson C. 1891. Descriptions of new species of North American bees. Transactions of the American Entomological Society 18: 49-66. Available from http://biodiversitylibrary.org/page/7524474 [accessed 29 Feb. 2016]

Robertson C. 1892. Description of new North American bees. American Naturalist 26: 267-274. Available from http://biodiversitylibrary.org/page/41111637 [accessed 29 Feb. 2016]

Robertson C. 1893. Notes on bees, with descriptions of new species. Transactions of the American Entomological Society 20: 145-149. Available from http://biodiversitylibrary.org/page/7508067 [accessed 29 Feb. 2016]

Robertson C. 1897. North American bees-descriptions and synonyms. Transactions of the Academy of Science of St. Louis 7: 315-356. Available from http://biodiversitylibrary.org/page/5792297 [accessed 29 Feb. 2016]

Robertson C. 1901. Some new and little-known bees. The Canadian Entomologist 33: 229-231. Available from http://biodiversitylibrary.org/page/27876572 [accessed 29 Feb. 2016] 
Robertson C. 1902a. Some new or little-known bees-II. The Canadian Entomologist 34: 48-49. Available from http://biodiversitylibrary.org/page/27876759 [accessed 29 Feb. 2016]

Robertson C. 1902b. Synopsis of Halictinae. The Canadian Entomologist 34: 243-250. Available from http://biodiversitylibrary.org/page/27876958 [accessed 29 Feb. 2016]

Robertson C. 1902c. Some new or little-known bees-IV. The Canadian Entomologist 34: 321-325. Available from http://biodiversitylibrary.org/page/27877036 [accessed 29 Feb. 2016]

Robertson C. 1903. Synopsis of Sphecodinae. Entomological News 14: 103-107. Available from http:// biodiversitylibrary.org/page/4614771 [accessed 29 Feb. 2016]

Sandhouse G.A. 1943. The type species of the genera and subgenera of bees. Proceedings of the United States National Museum 92: 519-619. Available from http://biodiversitylibrary.org/page/15767247 [accessed 29 Feb. 2016]

Say T. 1837. Descriptions of new species of North American Hymenoptera, and observations on some already described. Boston Journal of Natural History 1: 361-416. Available from http:// biodiversitylibrary.org/page/32414085 [accessed 29 Feb. 2016]

Schenck A. 1868. Beschreibung der nassauischen Bienen [Nachtrag 2]. Jahrbücher des Nassauischen Vereins fur Naturkunde 21-22: 269-382. Available from http://biodiversitylibrary.org/page/30370660 [accessed 29 Feb. 2016]

Schrottky C. 1901. Biologische Notizen solitärer Bienen von S. Paulo (Brasilien). Allgemeine Zeitschrift für Entomologie 6: 209-216. Available from http://biodiversitylibrary.org/page/25325028 [accessed 29 Feb. 2016]

Schrottky C. 1909. Nuevos himenópteros sudamericanos. Revista del Museo de la Plata 16: 137-149.

Schrottky C. 1911. Descripção de abelhas novas do Brazil e de regiões visinhas. Revista do Museo Paulista 8: 71-88. Available from http://biodiversitylibrary.org/page/10798589 [accessed 29 Feb. 2016]

Smith F. 1853. Catalogue of Hymenopterous Insects in the Collection of the British Museum. Part I. Andrenidae and Apidae. British Museum, London. Available from http://biodiversitylibrary.org/ page/18380248 [accessed 29 Feb. 2016]

Smith-Pardo A.H. 2009. A new species of Habralictus (Hymenoptera, Halictidae) from the Island of Grenada (Lesser Antilles) with comments on the insular species of the genus. ZooKeys 27: 51-58. http:// dx.doi.org/10.3897/zookeys.27.265

Spinola M. 1851. Hymenópteros. In: Gay C. (ed.) Historia Fisica y Politica de Chile..., Zoologia: 153569. Privately published, Paris.

Thomson C.G. 1869. Opuscula Entomologica [fasc. 1]. Lundbergska, Lund.

Vachal J. 1909. Collections recueillies par M. le Baron Maurice de Rothschild dans l'Afrique orientale. Insectes hyménoptères: Mellifères. Bulletin du Muséum national d'Histoire naturelle 15: 529-534. Available from http://biodiversitylibrary.org/page/5033410 [accessed 29 Feb. 2016]

Vachal J. 1911. Étude sur les Halictus d'Amérique (Hym.). Miscellanea Entomologica 19: 9-24.

Verhoeff C. 1890. Ein Beitrag zur deutschen Hymenopteren-Fauna. Entomologische Nachrichten 16: 321-336. Available from http://biodiversitylibrary.org/page/11394849 [accessed 29 Feb. 2016]

Warncke K. 1975. Beiträge zur Systematik und Verbreitung der Furchenbienen in der Türkei (Hymenoptera, Apoidea, Halictus). Polskie Pismo Entomologiczne 45: 81-123. 
Wcislo W.T., Danforth B.N. \& Mueller U.G. 1994. In memoriam George Campbell Eickwort (19491994). Insectes Sociaux 41: 461-463.

Wells W. \& Decker T. 2006. A comparison of three types of insect traps for collecting non-Formicidae Hymenoptera on the Island of Dominica. Southwestern Entomologist 31: 59-68.

Submitted: 13 September 2015

Accepted: 19 December 2015

Published: 10 March 2016

Topic editor: Koen Martens

Desk editor: Danny Eibye-Jacobsen 